\title{
Traces of the Past: Interpretation \& Dissemination
}

by:

Celene Zehr

A thesis submitted to the Faculty of Graduate and Postdoctoral Affairs in partial fulfillment of the requirements for the degree of

Master of Architecture

Carleton University

Ottawa, Ontario

(C) 2016

Celene Zehr 


\section{Traces of the Past:}

Interpretation \& Dissemination 


\section{The Ottawa River by Night}

A Poem by Margaret Atwood

In the full moon you dream more.

I know where I am: the Ottawa River

far up, where the dam goes across.

Once, mid storm, in the wide cold water

upstream, two long canoes full

of children tipped, and they all held hands

and sang till the chill reached their hearts.

I suppose in our waking lives that's the best

we can hope for, if you think of that moment

stretched out for years.

Once, my father

and I paddled seven miles

along a lake near here

at night, with the trees like a pelt of dark

hackles, and the waves hardly moving.

In the moonlight the way ahead was clear

and obscure both. I was twenty

and impatient to get there, thinking

such a thing existed.

None of this

is in the dream, of course. Just the thick square edged shape of the dam, and eastward

the hills of sawdust from the mill, gleaming as white

as dunes. To the left, stillness; to the right,

the swirling foam of rapids

over sharp rocks and snags; and below that, my father

moving away downstream

in his boat, so skilfully

although dead, I remember now; but no longer as old.

He wears his grey hat, and evidently

he can see again. There now,

he's around the corner. He's heading eventually

to the sea. Not the real one, with its sick whales

and oil slicks, but the other sea,

where there can still be

safe arrivals.

Only a dream, I think, waking

to the sound of nothing.

Not nothing. I heard: it was a beach, or shore,

and someone far off, walking.

Nowhere familiar. Somewhere I've been before.

It always takes a long time

to decipher where you are. 


\section{Abstract:}

The act of storytelling is an age old tradition that stems far beyond European settlement at the Chaudière Falls. Using interpretation principles, this thesis analyzes the traces of the past found at the Bronson Pulp Mill Ruins and the contextual as well as historical significance of its relation to the Chaudière Falls. Through an iterative process this thesis aims to examine the layers of the historical site by way of narrating the journey created by the Interpretation Centre in situ which also acts as the tool for dissemination.

How can the traces of the past be interpreted and translated into an architectural language that allows the journey to become the means of dissemination? 


\section{Acknowledgements:}

I would like to thank my thesis advisor Mariana Esponda for always posing the right questions; it encouraged me to keep searching until I found the right answers.

Thank you to the team at the National Capital Commision who were already working to make what I had set out to do with this thesis, a reality. Without the documentation and guidance that you provided, this thesis would not have been as multi-layered as it is today.

To my parents: thank you does not begin to cover how much I owe both of you. 


\title{
Table of Contents:
}

\author{
Abstract \\ Acknowledgements \\ Table of Contents \\ List of Illustrations \\ Prologue \\ Introduction \\ Part I: ................ Interpretation: \\ Interpretation Principles 1.1: 2 \\ Interpretation Centres $1.2 \vdots 8$ \\ Precedents $1.3 \vdots 10$ \\ Part II: ............. Traces of the Past $\vdots 17$ \\ Intangible Context $2.1: 19$ \\ Greater Context 2.2 : 26 \\ Surrounding Context $2.3 \div 29$ \\ Immediate Context $2.4 \div 33$ \\ Tangible Context $2.5: 44$ \\ Part III:............... Dissemination: 47 \\ Interpretation Centre Design $3.1: 48$ \\ External Design $3.2 \vdots 57$ \\ Internal Design $3.3: 64$ \\ Conclusion \\ Exhibitions $3.4: 77$ \\ Appendix \\ Bibliography




\section{List of Illustrations:}

Figure 1 Scales of Interpretation Celene Zehr, 2016

Figure 2 Project Approach Diagram Celene Zehr, 2016

Figure 3 Levels of Interpretation Celene Zehr, 2016

Figure $4 \quad$ Comparison of Interpretation Principles

Celene Zehr, 2016 / The ICOMOS Charter for the Interpretation and Presentation of Cultural Heritage Sites. Rep. Quebec: ICOMOS, 2008, Tilden, Freeman. Interpreting Our Heritage. Chapel Hill: U of North Carolina, 1977

Figure $5 \quad$ Paddington Reservoir Gardens

“Paddington Reservoir Gardens." Paddington Reservoir Gardens. Ed. Tonkin Zulaikha Greer. Tonkin Zulaikha Greer, 2009. Web. 4 Nov. 2015. <Http://Www.Tzg. Com.Au/Project/Paddington-Reservoir/>.

Figure $6 \quad$ Cultuurpark Westergasfabriek

"Cultuurpark Westergasfabriek." Gustafson Porter. Ed. Gustafson Porter. 25 Aug. 2013. Web. 04 Nov. 2015. <http://www.gustafson-porter.com/westergasfabriek/>.

Figure 7

Duisburg-Nord Industrial Park

“Duisburg Nord Landscape Park, DE." Duisburg Nord Landscape Park, DE. Ed. Latz+Partner. Latz+Partner, Web. 26 Sept. 2015. <http://www.latzundpartner.de/en/projekte/postindustrielle-landschaften/landschaftspark-duisburg-nord-de/>.

Figure 8 Mill City Museum

LeFevre, Camille. “Mill City Museum." Architectural Record Feb. 2004: 122-26. Figure 9 Pointe-à-callière Museum

“Pointe-à-callière Museum." Pointe-à-callière Museum. Ed. Dan Hanganu. Dan Hanganu Architectes, Web. 24 Sept. 2015. <http://www.hanganu.com/index. php/en/projects/28-projets/culturel/1995/59-pac-em>.

Figure 10 Geological Map

Celene Zehr, 2016 / Bond, Courtney C. J., and Robert U. Mahaffy. Where Rivers Meet: An Illustrated History of Ottawa. Woodland Hills, CA: Windsor
Publications, 1984. / "Earthquake Zones in Eastern Canada." Stephen Halchuk, Jim Lyons. Government of Canada, 26 Apr. 2013. Web. 04 Nov. 2015.

Figure 11 Ecology of the Site

Celene Zehr, 2016 / QLF Canada, comp. A Background Study for the Nomination of the Ottawa River Under the Canadian Heritage Rivers System. Publication. Petawawa: Canadian Heritage Rivers System, 2005.

Figure $12 \quad$ Origins of Names

Celene Zehr, 2016 / Ross, Alexander Herbert Douglas. Ottawa, past and Present. Toronto: Musson Book, 1927

Figure $13 \quad$ Habitation Timeline

Celene Zehr, 2016 / QLF Canada, comp. A Background Study for the Nomination of the Ottawa River Under the Canadian Heritage Rivers System. Publication. Petawawa: Canadian Heritage Rivers System, 2005.

Figure $14 \quad$ Algonquin Ceremony

Charles William Jefferys 1930

Figure $15 \quad$ Industry Timeline

Celene Zehr, 2016 / Bond, Courtney C. J., and Robert U. Mahaffy. "Where Rivers Meet: An Illustrated History of Ottawa." Woodland Hills, CA: Windsor Publications, 1984.

Figure $16 \quad$ Site Progression

Celene Zehr, 2016/ Bond, Courtney C. J., and Robert U. Mahaffy. "Where Rivers Meet: An Illustrated History of Ottawa." Woodland Hills, CA: Windsor Publications, 1984.

Figure 171852 Plan for the Chaudiere Island and Victoria Island Celene Zehr, 2016/ Bond, Courtney C. J., and Robert U. Mahaffy. "Where Rivers Meet: An Illustrated History of Ottawa." Woodland Hills, CA: Windsor Publications, 1984. 60

Figure 18 Destruction by Fire Celene Zehr, 2016 / “The District - Vision Chaudiere." Vision Chaudiere. Web. 03 Oct. 2015. 
Figure 19

Industrial Evolution

Celene Zehr, 2016 / Earl, Jeff. Thompson Perkins and Bronson Pulp Mills Site History and Evolution. Rep. Ottawa: Fern Mackenzie Consulting Architectural Historian, 2006.

\section{Figure $20 \quad$ Phases of Building}

Celene Zehr, 2016/Sattelberger, Peter, M.A., and Jeff Earl, M.Soc.Sc. Richmond Landing/Bronson Mill Ruins Public Access: Heritage Guidance Document. Rep. Maberly: Past Recovery Archaeological Services, 2015.

Figure 21 The Timber Slide and Bridge 1872

(MM Notman Collection I-78918.1) Sattelberger, Peter, M.A., and Jeff Earl, M.Soc.Sc. Richmond Landing/Bronson Mill Ruins Public Access: Heritage Guidance Document. Rep. Maberly: Past Recovery Archaeological Services, 2015. Figure 22 Section of a 'bird's eye view'

(LAC NMC 21082) Sattelberger, Peter, M.A., and Jeff Earl, M.Soc.Sc. Richmond Landing/Bronson Mill Ruins Public Access: Heritage Guidance Document. Rep. Maberly: Past Recovery Archaeological Services, 2015.

\section{Figure $23 \quad$ Ownership of the Surrounding Context}

Celene Zehr, 2016 / Earl, Jeff. Thompson Perkins and Bronson Pulp Mills Site History and Evolution. Rep. Ottawa: Fern Mackenzie Consulting Architectural Historian, 2006.

$\begin{array}{lll}\text { Figure 24 } & \text { Generating Station No. 2 } & \text { Celene Zehr, } 2016 \\ \text { Figure 25 } & \text { Thompson Perkins Mill } & \text { Celene Zehr, 2016 } \\ \text { Figure 26 } & \text { Thompson Perkins Mill Addition }\end{array}$

Celene Zehr, 2016

Figure 27

$$
\text { Dates of Construction }
$$

Celene Zehr, 2016 / Earl, Jeff. Thompson Perkins and Bronson Pulp Mills Site History and Evolution. Rep. Ottawa: Fern Mackenzie Consulting Architectural Historian, 2006.
Figure 28 Original Elevations of the Bronson Pulp Mill

Sattelberger, Peter, M.A., and Jeff Earl, M.Soc.Sc. Richmond Landing/Bronson Mill Ruins Public Access: Heritage Guidance Document. Rep. Maberly: Past Recovery Archaeological Services, 2015. 62-64

\section{Figure 29 How the Pulp Mill Functioned}

Celene Zehr, 2016 / Earl, Jeff. Thompson Perkins and Bronson Pulp Mills Site History and Evolution. Rep. Ottawa: Fern Mackenzie Consulting Architectural Historian, 2006.

\section{Figure $30 \quad$ Classification of Elements}

Celene Zehr, 2016 / HP Engineering. Bronson Pulp Mill Ruins National Capital Commission Draft Structural Assessment Report. Rep. Ottawa: National Capital Commission, 2015.

\section{Figure $31 \quad$ Level of Deterioration}

Celene Zehr, 2016 / HP Engineering. Bronson Pulp Mill Ruins National Capital Commission Draft Structural Assessment Report. Rep. Ottawa: National Capital Commission, 2015.

\begin{tabular}{|c|c|c|}
\hline Figure 32 & \multicolumn{2}{|c|}{ South Concrete Retaining Wall HP Engineering } \\
\hline Figure 33 & \multicolumn{2}{|l|}{ South Concrete Retaining Wall } \\
\hline Figure 34 & Stone Parapet & HP Engineering \\
\hline Figure 35 & Dry Stone Wall & HP Engineering \\
\hline Figure 36 & Concrete Log Chutes & HP Engineering \\
\hline Figure 37 & Concrete Basin & HP Engineering \\
\hline Figure 38 & \multicolumn{2}{|c|}{ Staircase to Grider Room and Roof } \\
\hline \multicolumn{3}{|c|}{ HP Engineering } \\
\hline Figure 39 & Turbine & HP Engineering \\
\hline Figure 40 & Furnace & HP Engineering \\
\hline Figure 41 & \multicolumn{2}{|l|}{ Dam Deck and Grinder Room Roof } \\
\hline \multicolumn{3}{|c|}{ HP Engineering } \\
\hline Figure 42 & Grinder Room Wall & HP Engineering \\
\hline
\end{tabular}




\begin{tabular}{|c|c|c|c|c|c|}
\hline Figure 43 & Steel Staircase & HP Engineering & Figure 63 & \multicolumn{2}{|c|}{ Views from the Interpretation Centre } \\
\hline Figure 44 & Upper Concrete Terrace & HP Engineering & Celene Zeh & & \\
\hline Figure 45 & Upper Concrete Terrace & HP Engineering & Figure 64 & Levels of Interpretation & Celene Zehr, 2016 \\
\hline Figure 46 & Lower Concrete Terrace & HP Engineering & Figure 65 & Journey Diagram & Celene Zehr, 2016 \\
\hline Figure 47 & Timber Lifting Device & Celene Zehr, 2016 & Figure 66 & Section 1 & Celene Zehr, 2016 \\
\hline Figure 48 & Turbine & HP Engineering & Figure 67 & Section 2 & Celene Zehr, 2016 \\
\hline Figure 49 & Grindstones & Celene Zehr, 2016 & Figure 68 & Level-2 & Celene Zehr, 2016 \\
\hline Figure 50 & Birds Eye View & Celene Zehr, 2016 & Figure 69 & Level-1 & Celene Zehr, 2016 \\
\hline Figure 51 & Site Components & Celene Zehr, 2016 & Figure 70 & Level 1 & Celene Zehr, 2016 \\
\hline Figure 52 & Standards \& Guidelines & Celene Zehr, 2016/ & Figure 71 & Level 2 & Celene Zehr, 2016 \\
\hline \multicolumn{3}{|c|}{ Standards and Guidelines for the Conservation of Historic Places in } & Figure 72 & Level 3 & Celene Zehr, 2016 \\
\hline \multicolumn{3}{|c|}{ Canada: A Federal, Provincial and Territorial Collaboration. 2nd ed. } & Figure 73 & Level 4 & Celene Zehr, 2016 \\
\hline \multicolumn{3}{|c|}{ Ottawa: Parks Canada, 2010.} & Figure 74 & Exhibition Diagram & Celene Zehr, 2016 \\
\hline Figure 53 & Site Plan & Celene Zehr, 2016 & Figure 75 & Intangible Context & Celene Zehr, 2016 \\
\hline Figure 54 & North Elevation & Celene Zehr, 2016 & Figure 76 & Tangible Context & Celene Zehr, 2016 \\
\hline Figure 55 & East Elevation & Celene Zehr, 2016 & Figure 77 & Immediate Context & Celene Zehr, 2016 \\
\hline Figure 56 & South Elevation & Celene Zehr, 2016 & Figure 78 & Surrounding Context & Celene Zehr, 2016 \\
\hline Figure 57 & West Elevation & Celene Zehr, 2016 & Figure 79 & Greater Context & Celene Zehr, 2016 \\
\hline Figure 58 & View from Bridge & Celene Zehr, 2016 & Figure 80 & Solid Vs. Void & Celene Zehr, 2016 \\
\hline Figure 59 & View From Driveway & Celene Zehr, 2016 & Figure 81 & Process Work & Celene Zehr, 2016 \\
\hline Figure 60 & \multicolumn{2}{|c|}{ Plan of the Remaining Site Infrastucture } & Figure 82 & View From the Water & Celene Zehr, 2016 \\
\hline
\end{tabular}




\section{Prologue:}

Behind every historical site is a multitude of layers that cannot be seen or understood from looking at the remaining fragments alone. My interest has always been in the background stories, what comprises the entire story behind one moment. It was my desire to begin to understand these unseen layers that led to the design of an Interpretation Centre. Through the use of an Interpretation Centre the visitor is allowed to make their own conclusions and learn about the aspects that interest them. Through the use of this learning opportunity, a platform is created that provides the visitor with a single location for this interpretation to disseminated. 


\section{Introduction:}

Having played a key role in the industrialization of Ottawa, the Bronson Pulp Mill Ruins are currently closed for public use and are therefore easily passed by. The translation of the sites history is similarly inaccessible to the general public. Owing in part to this isolation, as well as the historical significance of the site, the Bronson Pulp Mill Ruins are an intriguing subject upon which to investigate the three core concepts of this thesis, "traces of the past", “interpretation", and "dissemination". Vastly different from the next, each concept provides a key role in creating a layered and dynamic proposal. It is on these concepts that the fundamentals for the proposal of an Interpretation Centre located at the Bronson Pulp Mill Ruins are based.

The "Traces of the Past", that are the foundation of 


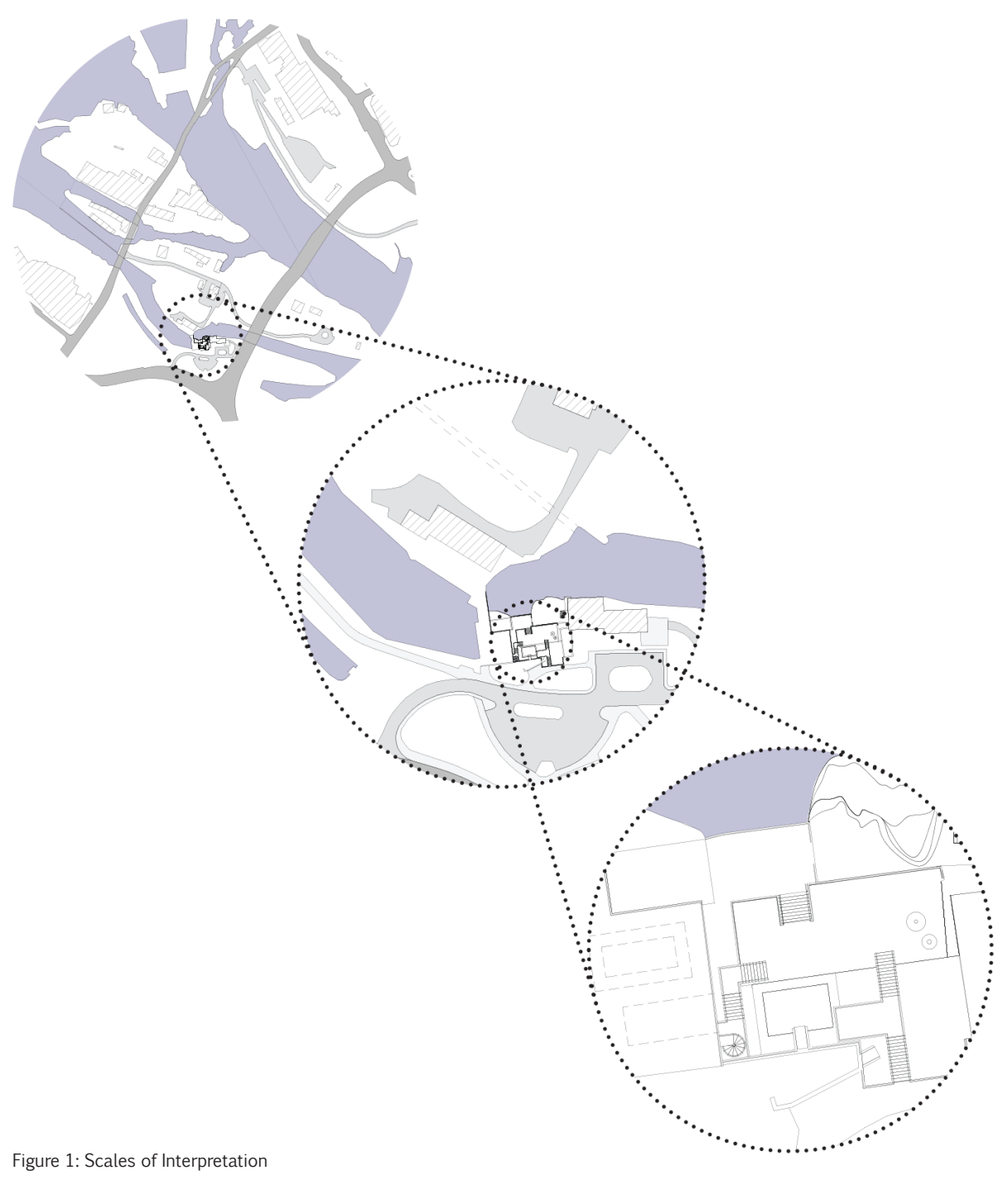

this thesis, can be found in the Chaudière Falls and surrounding islands. (Figure 1) These traces will be analyzed on increasing scales and interpreted using interpretation theories derived from Freeman Tilden's principles in his book Interpreting Our Heritage (1957) and the International Council on Monuments and Sites (ICOMOS) Charter for the Interpretation and Presentation of Cultural Heritage Sites (2008).

These three concepts need to work together to properly function. The traces of the past are existing entities based off of remnants and historical fact. They cannot be understood without analysis and the use of interpretation principles. This interpretation is meaningless unless it is disseminated to the general public; otherwise it remains stagnant and unused similar to the way a museum collects and 

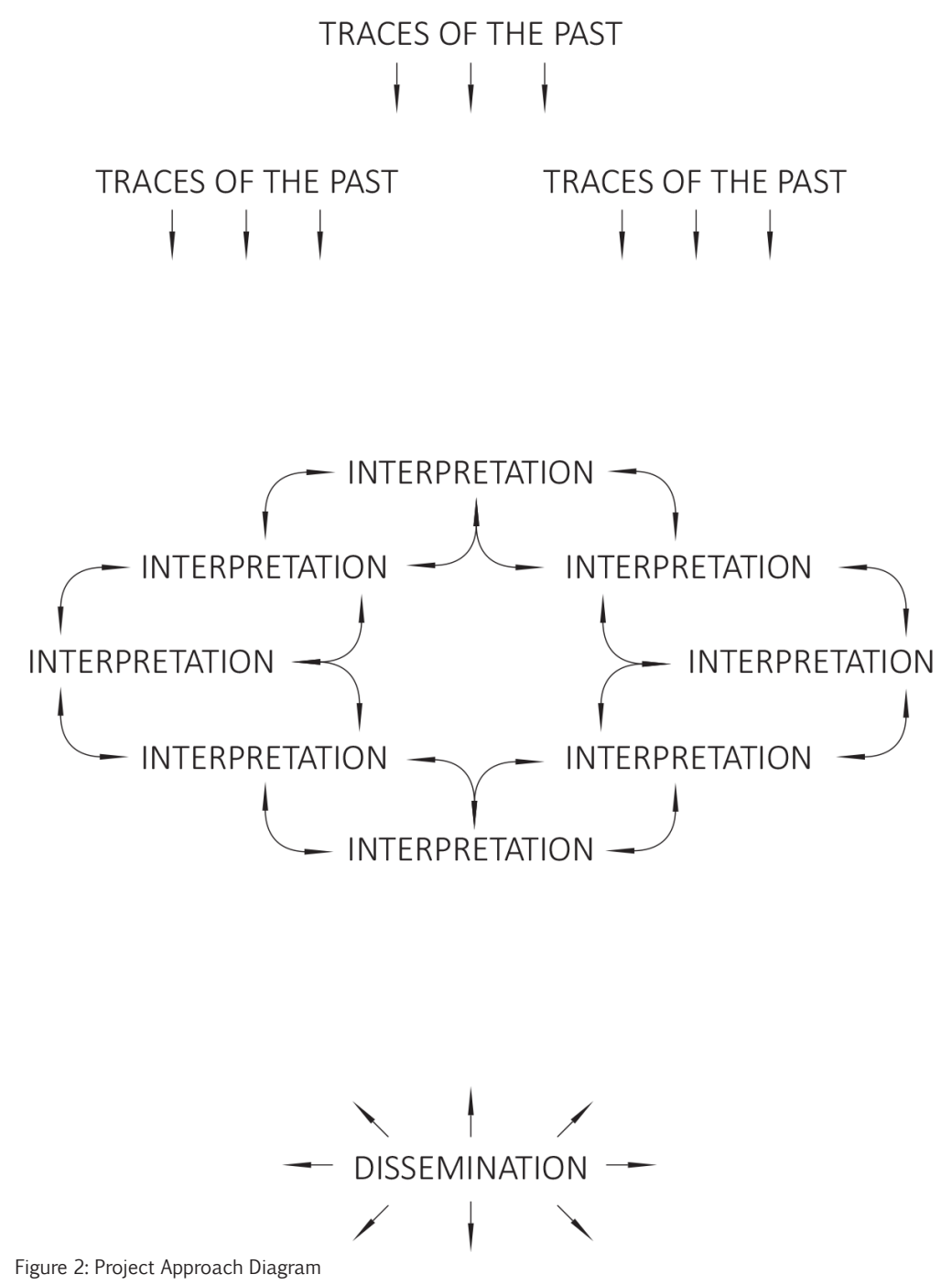

conserves artifacts that the public never sees. These three concepts create an interdependency that with one component removed cannot function. (Figure 2)

The Traces of the Past will be analyzed and interpreted through the lens of five distinct scales: the immediate context comprised of the proposed site located at the Bronson Pulp Mill Ruins. The surrounding context of the Bronson Pulp Mill Ruins will be the next scale examined; this includes the Thompson Perkins Mill and the Generating Station No. 2. Finally at the largest scale the greater context of the Chaudière Falls and islands will be analyzed. The final two scales of interpretation that occur are tangible and intangible aspects. These include artifacts and memory of the area. These scales of interpretation will be translated into an architectural language that will 


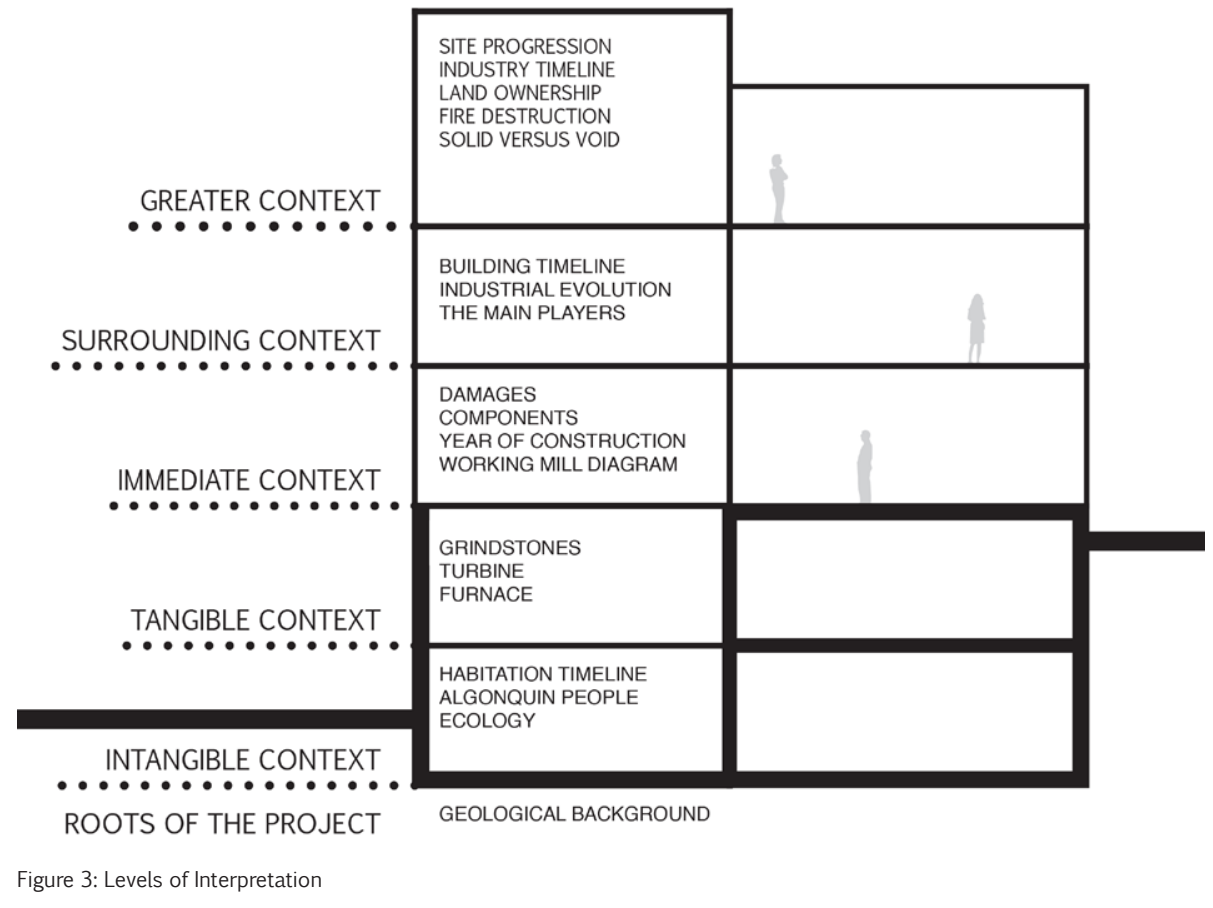

Figure 3: Levels of Interpretation tell the story of the Chaudière Falls through a journey within the Interpretation Centre. (Figure 3)

The significance of this site lies in the vast history that defines it. This history is made tangible through the remaining buildings which speak to the architectural and programmatic evolution of the site. The presence of Generating Station No. 2 speaks to the expansion into hydroelectric power, the Thompson Perkins Mill speaks to the timber industry, and the evolution of this industry is seen through the Bronson Pulp Mill. This node creates a gateway into the Chaudière Falls as the proposed Interpretation Centre provides an opportunity as a new destination and for visitors to engage with the history of Ottawa. It is through the Interpretation Centre that new life will be brought back to the ruins, and its story and 
the stories from the Chaudière Falls will once again be available to the public.

During the last six months a series of meetings were held with the National Capital Commission (NCC), who is currently working to develop a way of allowing the public to interact with the Bronson Pulp Mill Ruins. After discussions with the NCC, the program requirements for the site were established, these included: accessibly, safety, refurbishment, and proper exhibition of artifacts. This program in conjunction with the proposed Interpretation Centre will allow the site to be fully maximized in terms of allowing the visitor to completely immerse themselves within the site. 
Part I:

Interpretation 


\section{Interpretation Principles 1.1:}

The interpretation of heritage sites was first approached by Freeman Tilden in his book "Interpreting Our Heritage" published in 1957. The principles that he established were to be applied to National Parks in America. Tilden describes heritage interpretation as "an educational activity which aims to reveal meanings and relationships through the use of original objects, using firsthand experience, and illustrative media, rather than just communicating factual information."1

He found that the experience of reading interpretation has different meanings to different people. For the interpreter it is the revelation of a larger truth lying behind any statement of fact, and those reading the interpretation "should capitalize mere curiosity for the enrichment of the human mind and spirit."2
The interpretation should be based off of cultural, natural, material, and immaterial: and can be found in any location. ${ }^{3}$ The aim of interpretation is to provide guidance to the visitor and allow them to "see, explore, situate, observe, analyse, understand, feel, and truly experience the site."4 The six principles that Freeman Tilden established are as follows:

I. Any interpretation that does not somehow relate what is being displayed or described to something within the personality or experience of the visitor will be sterile.

II. Information, as such, is not Interpretation. Interpretation is revelation based upon information. But they are entirely different things. However, all interpretation includes information. 
III. Interpretation is an art, which combines many arts, whether the materials presented are scientific, historical or architectural. Any art is in some degree teachable.

IV. The chief aim of Interpretation is not instruction, but provocation.

V. Interpretation should aim to present a

\section{whole rather than a part.}

VI. Interpretation addressed to children (say, up to the age of twelve) should not be a dilution of the presentation to adults,

but should follow a fundamentally different approach. To be at its best it will require a separate program. ${ }^{5}$

When these principles are discussed in tandem with the more modern and methodical ICOMOS principles an interesting dynamic and relationship begins to occur. Tilden's principles look more to the emotional connection with the interpretation, looking at provocation, art and revelation that the interpretation presents. While ICOMOS's principles look at the practicality of the interpretation and act as a set of guidelines.

The ICOMOS principles of interpretation are:

1. Access and Understanding

2. Information Sources

3. Attention to Setting and Context

4. Preservation of Authenticity

5. Planning for Sustainability

6. Concern for Inclusiveness

7. Importance of research, training, and evaluation $^{6}$ 


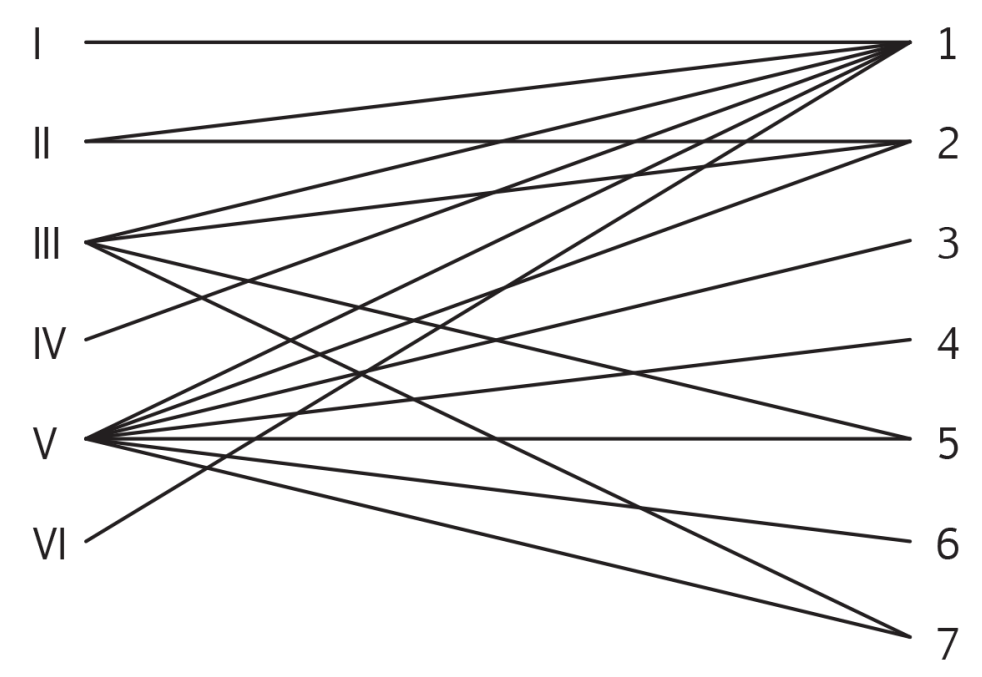

Figure 4: Comparison of Interpretation Principles
Through the combination and relationship of these two sets of principles; interpretation of heritage sites becomes more experiential. Comparing each set of principles side by side does not create an exact match up of ideals; as many of Freeman Tilden's principles apply to multiple ICOMOS principles. (Figure 4)

\section{Access and Understanding}

Access and Understanding's main emphasis according to ICOMOS is to allow physical and intellectual access that will enhance the experience individuals encounter with the intention of increasing public respect and understanding of the site. The reflection that occurs will hopefully solidify the connection that these individuals and communities have to the site. ${ }^{7}$ 
Freeman Tilden's main approach to interpretation was similar to this single principle by ICOMOS as all his principles align with it. He suggests that presenting something that does not relate to the direct context will not improve the individuals experience rather it will make it sterile. He addresses that information is not interpretation rather interpretation is the revelation that one makes from information. Another relatable aspect is that all interpretation is teachable and through this instruction it will further the understanding of the site. When interpretation is presented as a taught subject, it is imperative that the entirety of the story to be presented, by not doing so the interpretation will be incoherent and not intellectually accessible. Finally Tilden makes a statement that is similar to ICOMOS; it must be understood that different types of interpretation are meant for different audiences; children's interpretation should be presented in a different manner then adults. $^{8}$

\section{Information Sources}

With information sources it is important that a range of research methods be represented. These include scientific and scholarly methods but also looking at oral and cultural traditions and the remaining ma-

terial evidence. This allows the interpretation to become a well-researched and multidisciplinary study and reflection. When visual reproduction occurs it should be based off of these methods and used in combination with each other. ${ }^{9}$ Tilden states interpretation to be an art, but states that it is presented in a manner that is still teachable. Also that information is able to have a revelation, which can be 
done through the accumulation of different sources, and different points of view. ${ }^{10}$

\section{Context and Setting}

Context and setting when looking at a heritage site can be considered one of the most important aspects of interpretations as it "should relate to the wider social, cultural, historical and natural context." ${ }^{\prime 11}$ The interpretation should be multi-faceted and consider all aspects. Everything must be in relation to each other and when they occur within the evolution of the site. ${ }^{12}$ Tilden's main principle that relates to the context and setting is that the interpretation must present the whole and address itself to all parties involved in the context of the heritage site. ${ }^{13}$

\section{Authenticity}

Authenticity of heritage sites according to ICOMOS must look to the Nara Document on Authenticity (1994). It is important that all aspects of the site be protected, including the built fabric, the cultural practices and communities both of the past and current. Any new infrastructure "must be sensitive to the character, setting and the cultural and natural significance of the site, while remaining easily identifiable."14 Again Tilden requires that the whole be presented, referencing not only the history, but also the people involved in the site. ${ }^{15}$

\section{Sustainability}

Sustainability is a current widespread practice and through its use it can serve as an educational tool for conservation and cultural objectives. When 
rehabilitating heritage sites, the interpretation of the site can reflect this process as a learning tool and be used to teach new methods to the public. ${ }^{16}$ Tilden also used this aspect, treating interpretation as an art, and using it as a tool to further educate. ${ }^{17}$

\section{Inclusiveness}

Inclusiveness looks to include all parties who have stakes in the history of the site. This will result in a meaningful collaboration and a multidisciplinary result. It is important that all parties be respected. ${ }^{18}$ The Tilden principle that will encompass inclusiveness is that the aim of interpretation is to present the whole, as its goal is to include all aspects of the heritage site. ${ }^{19}$
Research, Training and Evaluation

With research, training and evaluation the core idea is that it is a continuation, and is never considered complete. There are always aspects to a project, and by expanding more learning is able to occur. ${ }^{20}$ This interpretation can be used as a resource for educational purposes, and as a reference for other similar sites. ${ }^{21}$ Tilden's principle that relates to this is when looking at the continuing interpretation as an art, and treating what happens on this site as something that can be taught for future heritage sites ${ }^{22}$

Using the "Charter for the Interpretation and Presentation of Cultural Heritage Sites" by ICOMOS and relating it to Freeman Tilden's book "Interpreting Our Heritage" these principles will be used to manifest the interpretation in this thesis. 


\section{Interpretation Centre 1.2:}

Once the interpretation using the previously mentioned principles has taken place a method of communicating the information is required. It is through this process of communication that dissemination takes a role. Dissemination is the "sending and receiving" through "speakers and hearers". When dissemination occurs the receiver is often unknown, and the effect of the spoken word has unknown consequences. Through the use of dissemination, information can reach parties which otherwise would have been inaccessible. It is up to each of these individuals to understand what is being said, this means that each party may take a different meaning away from the communication. ${ }^{23}$

In the case of interpretation the most common method of dissemination is the use of an Interpretation
Centre. These facilities encourage interaction with the heritage aspects, and use various methods of releasing the material and information. Different from museums, interpretation centres "do not aim to collect, conserve and study objects; rather they enable visitors to gain a better appreciation of the site's natural and cultural values by providing the necessary information. ${ }^{24}$

The main purpose of an Interpretation Centre is to educate and raise awareness. These facilities are created to evaluate the cultural and natural heritage of sites, making the information accessible to the general population, and allowing the uniqueness of the area to show. ${ }^{25}$

When planning out heritage interpretation centres 
there are three key areas that should be considered: the public, the heritage and the physical spaces. The public must have a comfortable and high quality experience; this is done through reception, guidance, and circulation. The heritage should be allowed to be properly incorporated into the design. It should have the proper research requirements that facilitate future interpretation; including the presentation, communication, and exploitation of the interpretation. Finally the physical space should have a relation with their function, the circulation, and meet environmental, safety, and security needs. ${ }^{26}$

Interpretation always has an objective, a point which it is trying to achieve. These objectives are a declaration of intentions and set the framework for the Interpretation Centre.
The main objectives of an Interpretation Centre are:

- Economic

- Social

- Identity

- Cultural

- Educational

- Dissemination

- Cultural Tourism ${ }^{27}$

It is through the Interpretation Centre that the public begins to interact with the heritage site, and an application of the historical significance can begin to develop. 


\section{Precedents 1.3:}

The following five precedents have been analyzed and explored with the common themes of traces of the past, interpretation and dissemination being referenced. Each project is based out of existing traces of the past and incorporates these traces into the new design in various forms. The interpretation that has taken place can be seen in the new built form of the project. Whether this is done through the architect's or user's interpretation varies per project. Finally these projects have disseminated the information presented in different ways, either through the architecture itself or within the program. Each of these projects presents the way the research completed in this thesis manifests in the built environment. 

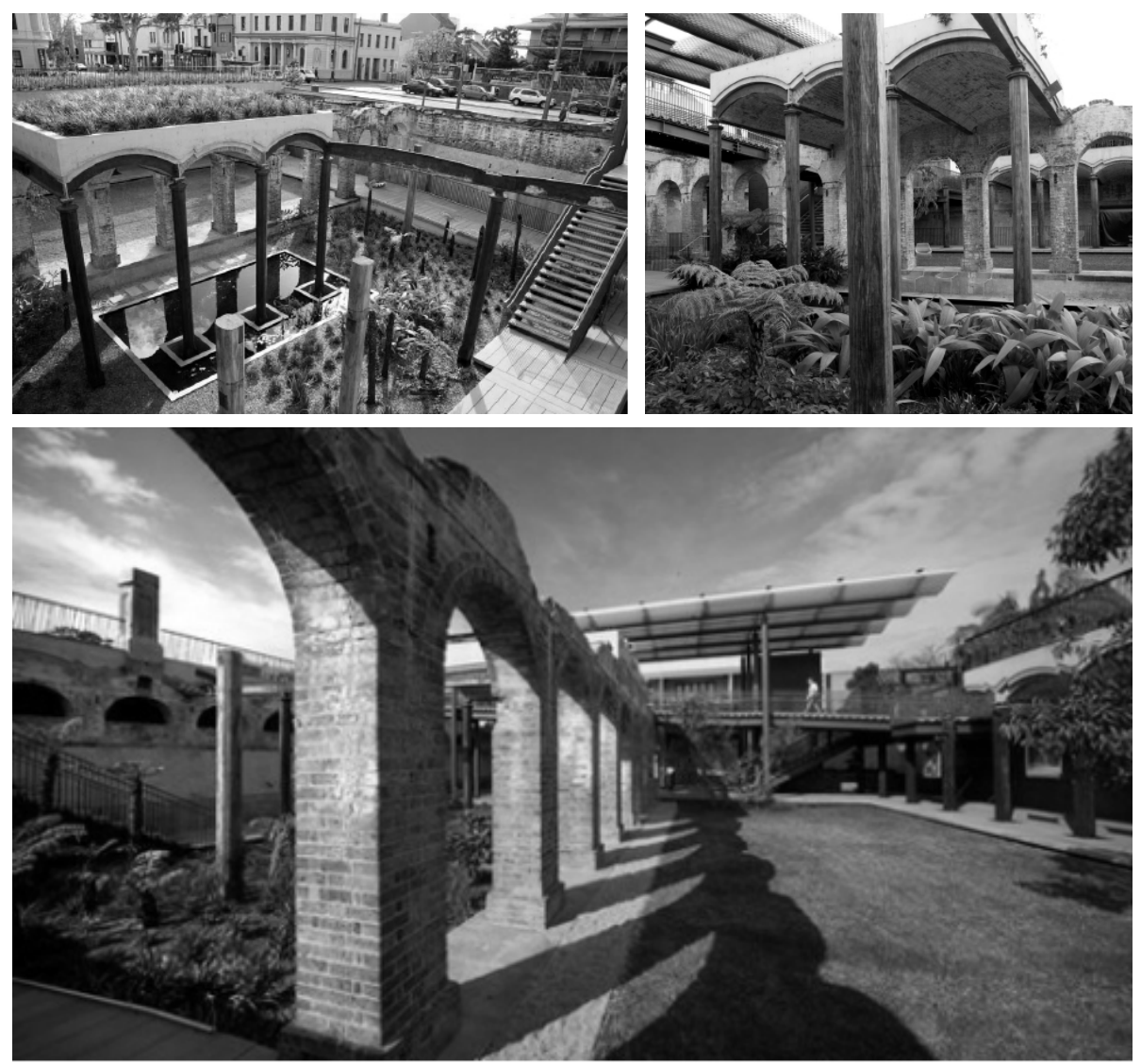

Figure 5: Paddington Reservoir Gardens

\section{Paddington Reservoir Gardens ${ }^{28}$}

Architect:

Tonkin Zulaikha Greer

Location:

Sydney, Australia

Year:

2006

Previous Program: Reservoir

Program:

Landscape Park

Traces of the Past: The remains include brickwork, timber and iron structures.

Interpretation: It is a sunken garden with modern elements and access.

Dissemination: Only elements remain, with little indication of the previous use. The main remnants of its past include the layers of preserved graffiti illustrating the extensive periods of neglect. 


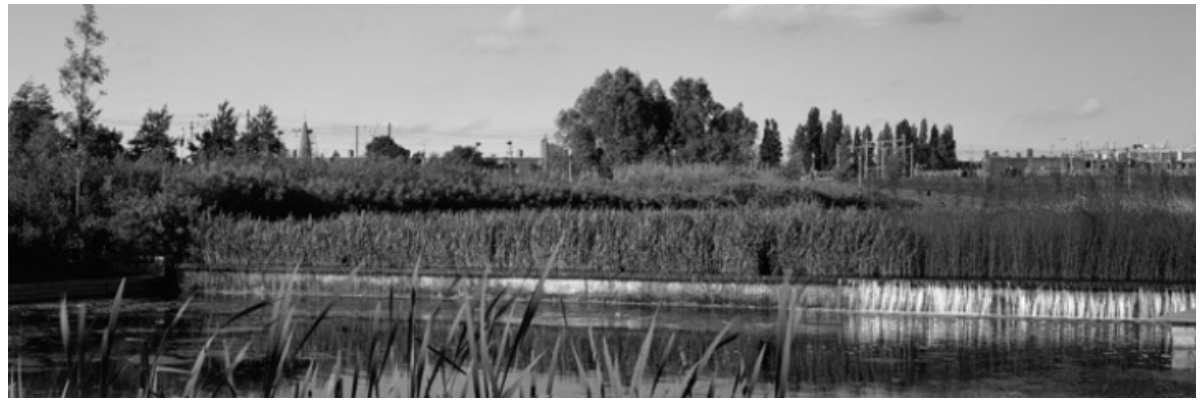

\section{Cultuurpark Westergasfabriek ${ }^{29}$}

Architect: Gustafson Porter

Location: $\quad$ Amsterdam, Netherlands

Year:

2004

Previous Program: Gasworks

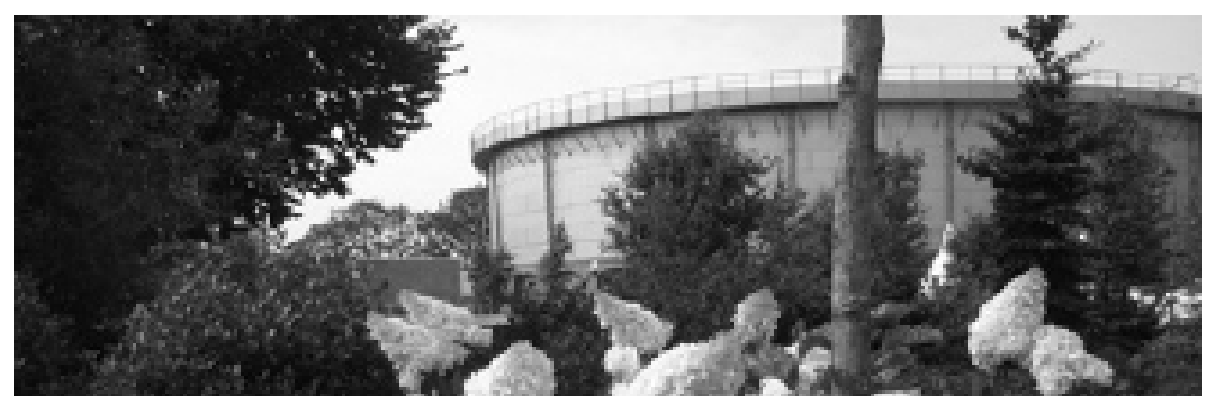

Program:

Landscape Park

Traces of the Past: The remains include remnants of the gasworks.

Interpretation: The aim was to incorporate historic landscape design strategies that were incorporated around the remaining buildings.

Dissemination: The recycling of the site includes the use of recycled materials and sustainable approaches and in the process teaches these methods. 

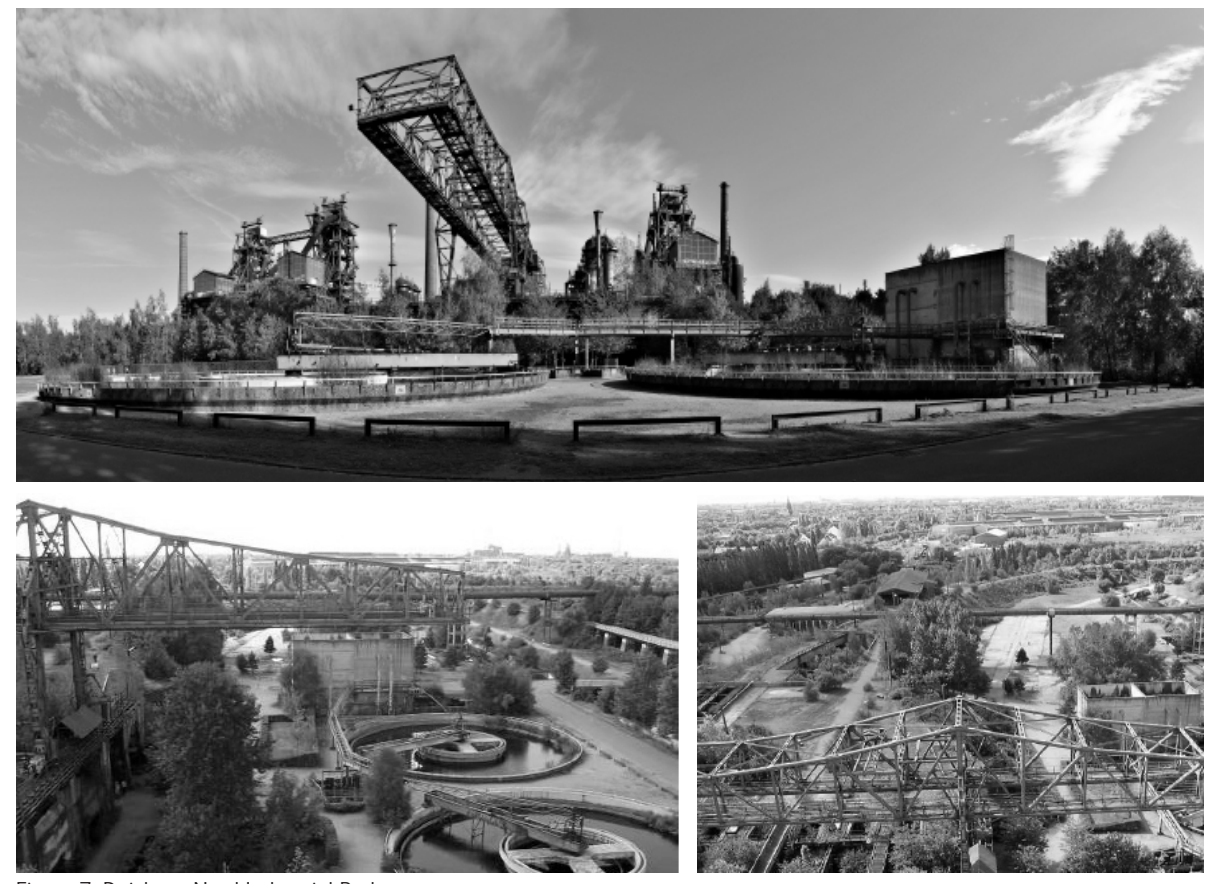

Figure 7: Duisburg-Nord Industrial Park

\section{Duisburg-Nord Industrial Park ${ }^{30}$}

Architect:

Peter Latz

Location: Germany

Year:

1990-2002

Previous Program: Industrial Site

Program: $\quad$ Landscape Park

Traces of the Past: The remains of a large industrial park still showcase the patterns that were formed over years of development.

Interpretation: The existing fragments were transformed into a landscape park that has various uses.

Dissemination: The project focuses on cultural works, with various program functions in the different buildings. 

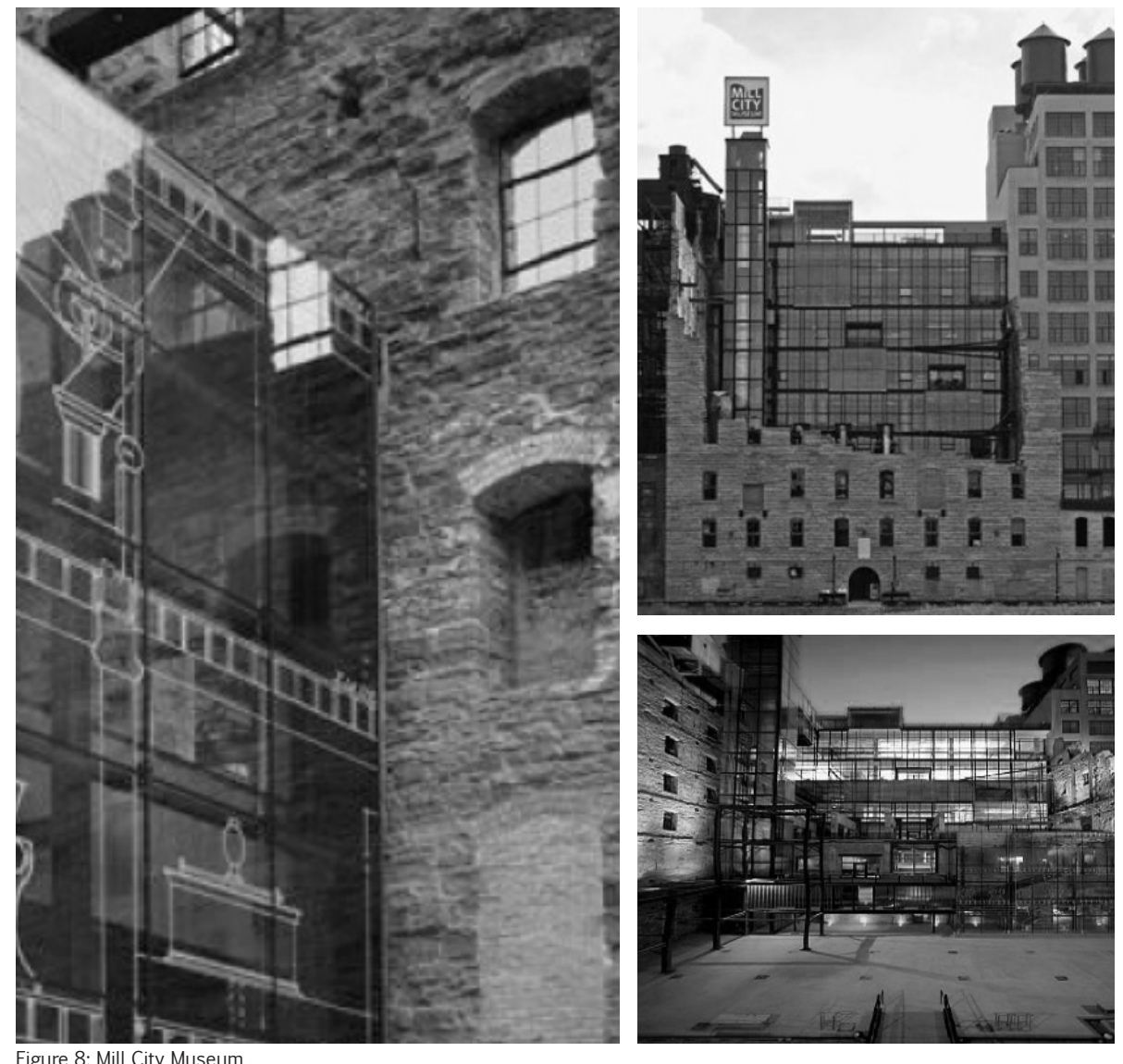

Figure 8: Mill City Museum

\section{Mill City Museum ${ }^{31,32}$}

Architect: $\quad$ Meyer, Scherer, \& Rockcastle

Location: Minneapolis, USA

Year:

2003

Previous Program: Mill

Program: Museum

Traces of the Past: The existing flour mill has had an extensive built history, including multiple phases of destruction and rebuilding.

Interpretation: From the ruins new built spaces are formed.

Dissemination: The new program is a museum with its focus on the history of the area. This imparts the information and history to the visitors. 

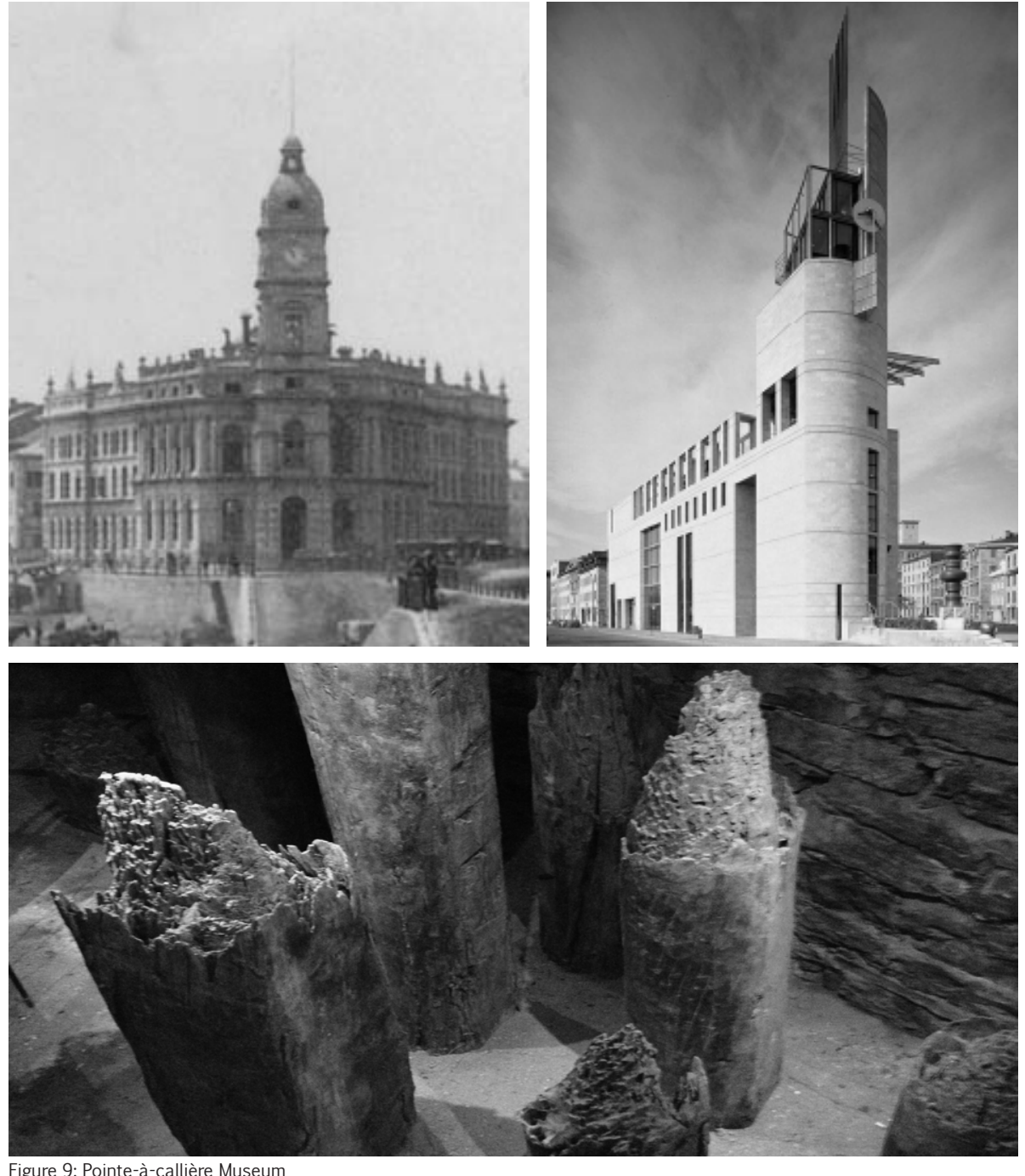

Figure 9: Pointe-à-callière Museum

\section{Pointe-à-callière Museum ${ }^{33}$}

Architect: Dan Hanganu

Location: $\quad$ Montreal, Quebec

Year:

1990-1992

Previous Program: Customs House

Program: $\quad$ Museum

Traces of the Past: The project is built from remnants of the original foundation and mimics the previous building on the site.

Interpretation: The project was built over the remains of the old, and became an interpretation of the old.

Dissemination: The program of an Archeology Museum, the new building utilizes the foundations as methods of explaining the concept. 


\section{Endnotes Part l:}

1. Tilden, Freeman. Interpreting Our Heritage. Chapel Hill:U of North Carolina, 1977, 8. Tilden, Freeman. Interpreting Our Heritage. Chapel Hill: U of North Carolina, 1977, 8. Izquierdo Tugas, Pere, Jordi Juan Tresserras, and Juan Carlos Matamala Mellin, Eds. The Hicira Handbook - Heritage Interpretation Centres. Rep. Barcelona: Diputació De Barcelona, 2005. 15.

4. Izquierdo Tugas, Pere, Jordi Juan Tresserras, and Juan Carlos Matamala Mellin, Eds. The Hicira Handbook - Heritage Interpretation Centres. Rep. Barcelona: Diputació De Barcelona, 2005. 16.

5. Tilden, Freeman. Interpreting Our Heritage. Chapel Hill:U of North Carolina, 1977, 9.

The ICOMOS Charter for the Interpretation and Presentation of Cultural Heritage Sites. Rep. Quebec: ICOMOS, 2008, 5.

7. The ICOMOS Charter for the Interpretation and Presentation of Cultural Heritage Sites. Rep. Quebec: ICOMOS, 2008, 7.

8. Tilden, Freeman. Interpreting Our Heritage. Chapel Hill:U of North Carolina, 1977, 9 .

9. The ICOMOS Charter for the Interpretation and Presentation of Cultural Heritage Sites. Rep. Quebec: ICOMOS, 2008, 8

10. Tilden, Freeman. Interpreting Our Heritage. Chapel Hill:U of North Carolina, 1977, 9.

11. The ICOMOS Charter for the Interpretation and Presentation of Cultural Heritage Sites. Rep. Quebec: ICOMOS, 2008, 9 .

12. The ICOMOS Charter for the Interpretation and Presentation of Cultural Heritage Sites. Rep. Quebec: ICOMOS, 2008, 9 .

13. Tilden, Freeman. Interpreting Our Heritage. Chapel Hill:U of North Carolina, 1977, 9

14. The ICOMOS Charter for the Interpretation and Presentation of Cultural Heritage Sites. Rep. Quebec: ICOMOS, 2008, 10

15. Tilden, Freeman. Interpreting Our Heritage. Chapel Hill: U of North Carolina, 1977, 9.

16. The ICOMOS Charter for the Interpretation and Presentation of Cultural Heritage Sites. Rep. Quebec: ICOMOS, 2008, 11

17. Tilden, Freeman. Interpreting Our Heritage. Chapel Hill: U of North Carolina, 1977, 9.

18. The ICOMOS Charter for the Interpretation and Presentation of Cultural Heritage Sites. Rep. Quebec: ICOMOS, 2008, 12

19. Tilden, Freeman. Interpreting Our Heritage. Chapel Hill:U of North Carolina, 1977, 9.

20. The ICOMOS Charter for the Interpretation and Presentation of Cultural Heritage Sites. Rep. Quebec: ICOMOS, 2008, 13

21. The ICOMOS Charter for the Interpretation and Presentation of Cultural Heritage Sites. Rep. Quebec: ICOMOS, 2008, 14

22. Tilden, Freeman. Interpreting Our Heritage. Chapel Hill:U of North Carolina, 1977, 9.

23. Durham Peters, John. "Communication as Dissemination." Communication as ...: Perspectives on Theory. Thousand Oaks, CA: Sage Publications, 2006. 212
24. Izquierdo Tugas, Pere, Jordi Juan Tresserras, and Juan Carlos Matamala Mellin, Eds. The Hicira Handbook - Heritage Interpretation Centres. Rep. Barcelona: Diputació De Barcelona, 2005.31.

25. Izquierdo Tugas, Pere, Jordi Juan Tresserras, and Juan Carlos Matamala Mellin, Eds. The Hicira Handbook - Heritage Interpretation Centres. Rep. Barcelona: Diputació De Barce lona, 2005. 41

26. Izquierdo Tugas, Pere, Jordi Juan Tresserras, and Juan Carlos Matamala Mellin, Eds. The Hicira Handbook - Heritage Interpretation Centres. Rep. Barcelona: Diputació De Barcelona, 2005. 47

27. Izquierdo Tugas, Pere, Jordi Juan Tresserras, and Juan Carlos Matamala Mellin, Eds. The Hicira Handbook - Heritage Interpretation Centres. Rep. Barcelona: Diputació De Barcelona, 2005. 27/28

28. "Paddington Reservoir Gardens." Paddington Reservoir Gardens. Ed. Tonkin Zulaikha Greer. Tonkin Zulaikha Greer, 2009. Web. 4 Nov. 2015. <Http://Www.Tzg.Com.Au/Project/Paddington-Reservoirs.

29 "Cultuurpark Westergasfabriek." Gustafson Porter. Ed. Gustafson Porter. N.p., 25 Aug. 2013. Web. 04 Nov. 2015. <http://www.gustafson-porter.com/westergasfabriek/>.

30. "Duisburg Nord Landscape Park, DE" Duisburg Nord Landscape Park, DE Ed Latz+Partner.Latz+Partner, n.d. Web. 26Sept. 2015. <http://www.latzundpartner.de/en/projekte/ postindustrielle-landschaften/landschaftspark-duisburg-nord-de/>.

31. Bollack, Françoise Astorg. Old Buildings, New Forms: New Directions in Architectural Transformations. New York: Monacelli, 2013.

32. LeFevre, Camille. "Mill City Museum." Architectural Record Feb. 2004: 122-26.

33. "Pointe-à-callière Museum." Pointe-à-callière Museum. Ed. Dan Hanganu. Dan Hanganu Architectes, n.d. Web. 24 Sept. 2015. <http://www.hanganu.com/index.php/en/ projects/28-projets/culturel/1995/59-pac-em>. 
Part II:

Traces of the Past 


\section{Traces of the Past:}

The Genius Loci or "Sense of Place" is an elusive quality that has had many meanings over the course of its existence. Its use references the atmosphere of the site and its quality of environment. ${ }^{34}$ The Chaudière Falls is an example of a site that has these qualities. There is a rich history established from the layers made up of the different traces of the past, and through its interpretation they will be kept and given a continuation of life.

Part II: Traces of the Past is comprised of five sections that tell the story of the Chaudière Falls: Intangible Context, Greater Context, Surrounding Context, Immediate Context, and Tangible Context. Through these sections, all the different layers that make up the Chaudière Falls will be examined and interpreted using the interpretation principles found in Part I
These layers will then be used within the Interpretation Centre to frame the journey that the public will take through the space. 


\section{Intangible Context 2.1:}

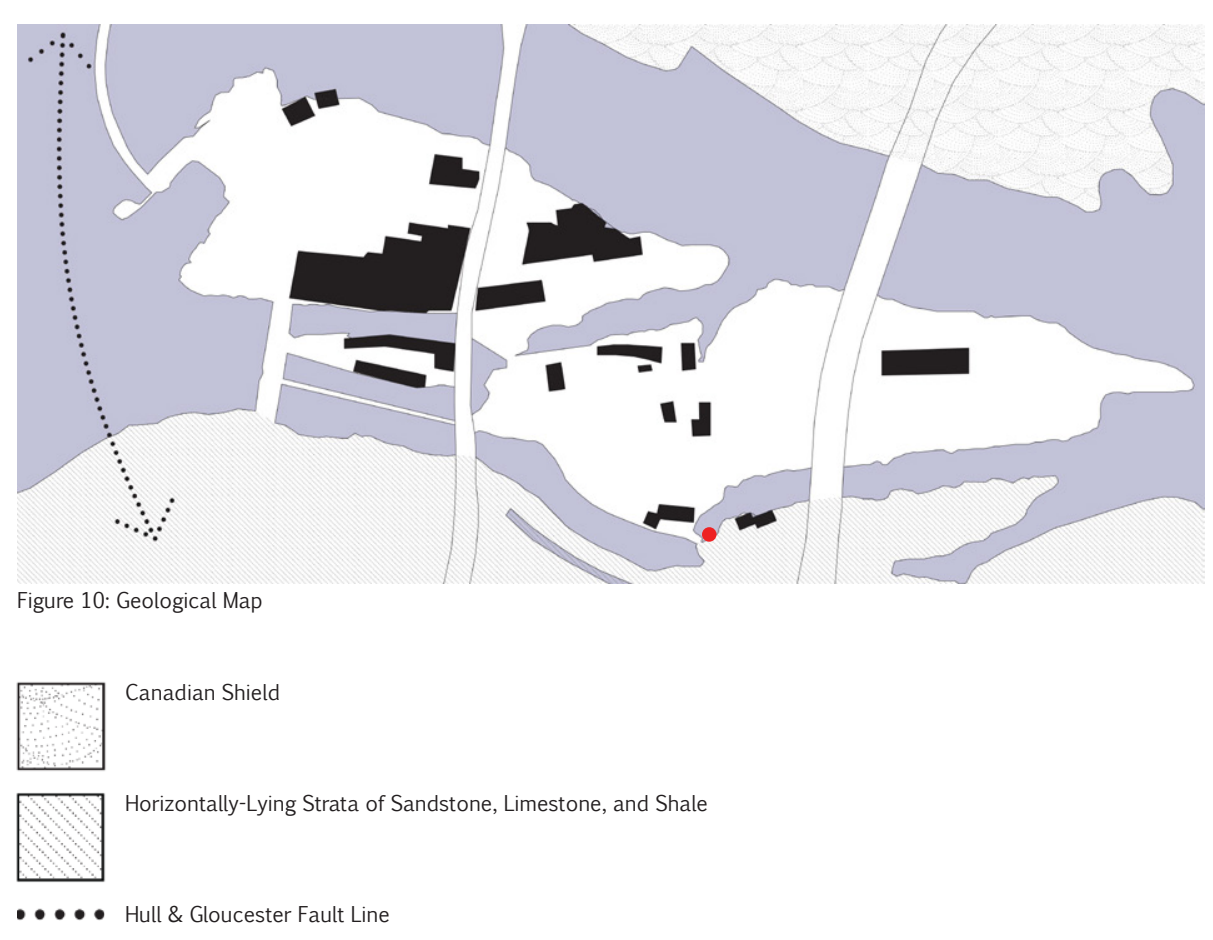

•... Hull \& Gloucester Fault Line
The Chaudière Falls is a historic area and its location is the predominate reason why many different groups have settled in this region over the centuries. Located within the Western Quebec Seismic Zone, the proximity to the Gloucester fault line causes multiple small earthquakes to occur yearly. ${ }^{35}$ This vicinity to the fault line is the reason cliffs have developed overtime, and has led to the creation of the Chaudière Falls, as well as the iconic cliffs upon which Parliament is situated. ${ }^{36}$ Located along the Ottawa River, the Chaudière Falls is where two different geological areas converge: the Canadian Shield to the North, and to the south "horizontally-lying strata of sandstone, limestone, and shale which outcrop here and there". ${ }^{37}$ (Figure 10)

The Ottawa River houses a diverse ecosystem of 


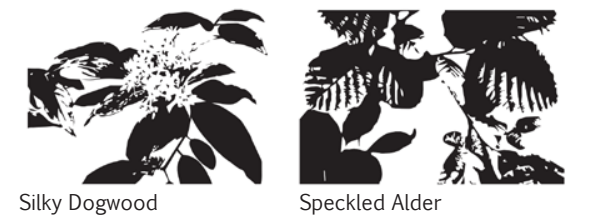

Figure 11a: Ecology of the Site

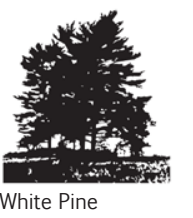

Maple Tree

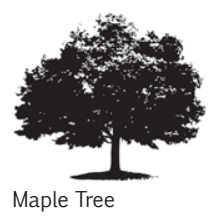

Spruce

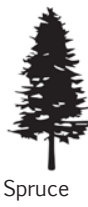

plant matter as well as aquatic and animal life in its waters and along its shores. (Figure 11) Due to the fast moving waters most of the plants in the water are algae or larger aquatic plants located in the slower moving waters that occur where deep lakes are located..$^{38}$ Vegetation is more common along the shores of the river. This plant type is known as riparian vegetation and it stabilizes the riverbank by helping with rain runoff and flood control. ${ }^{39}$ Some of these plant species include the Speckled Alder, Silky Dogwood, Sweet Gale, and numerous fern species. ${ }^{40}$ The forest typology differs between the north shore and south shore. In the north it is mostly coniferous trees including: Jack Pine, Spruce, Balsam Fir, Trembling Aspen, White Birch, and Balsam poplar. In the south it is composed of a mix of coniferous and deciduous including Maples, Pine, Eastern White 


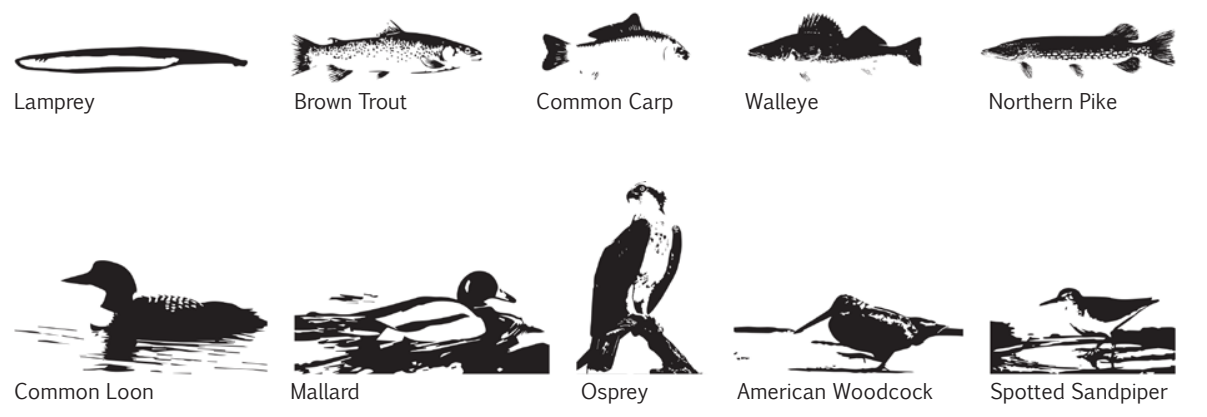

Figure 11b: Ecology of the Site
Cedar, Tamarack, White Spruce, Red Oak, Basswood, Ash, Poplar, and Birch. ${ }^{41}$

The aquatic life within the Ottawa River has a large diversity with as many as 85 different types of fish known to live within its waters at various locations. This distribution is known to be affected by the development along the river, particularly dams which halt the migration of certain species. ${ }^{42}$ With the association of the forests in the areas, comes the relationship of the many bird species that frequent the region. Over 300 different types of birds are common along the shores of the Ottawa River, with around half being migratory. ${ }^{43}$ All of these elements combined create a varied and intertwined ecosystem along the Ottawa River. 


\section{Ottawa ot:ta·wa/átawà/}

$\begin{array}{ll}\text { Cheveux Releves } & \text { Champlain } \\ \text { Outaouak } & \text { Jesuit Relations (1654-6) } \\ \text { Outaoua } & \text { Dollier de Casson (1665) } \\ \text { Outaouais } & (1700) \\ \text { Ottawa } & \end{array}$

\section{Ottawa River ot:ta-wa river/átawà rívar/}

Kit-chi-sippi

La Grande Rivière du Nord

The Grand River

Algonquins

French Explorers

Old-time lumbermen

\section{Chaudière Falls chau-dière Falls /Jodjer fólz/}

Asticou (Kettle)

Chaudière (Kettle)

Figure 12: Origins of Names
The names "Chaudière Falls", "Ottawa River" and the use of the name "Ottawa" itself has evolved over the last 400 years. The progression of these words has undergone numerous iterations since they were first used by the Algonquin. (Figure 12)

"Ottawa" is a name that has taken many forms. When the French explorer Samuel de Champlain began to discover the new world, he encountered a group of Natives whose name was unknown. He called them Cheveux Releves, or "Standing Hairs", based off of their tradition of styling their hair. This group was later called in the Jesuit Relations (1654-6) “Outaouak", and by Dollier de Casson in 1665 “Outaoua". This spelling was changed to "Outaouais" after 1700 and eventually took the form "Ottawa." 


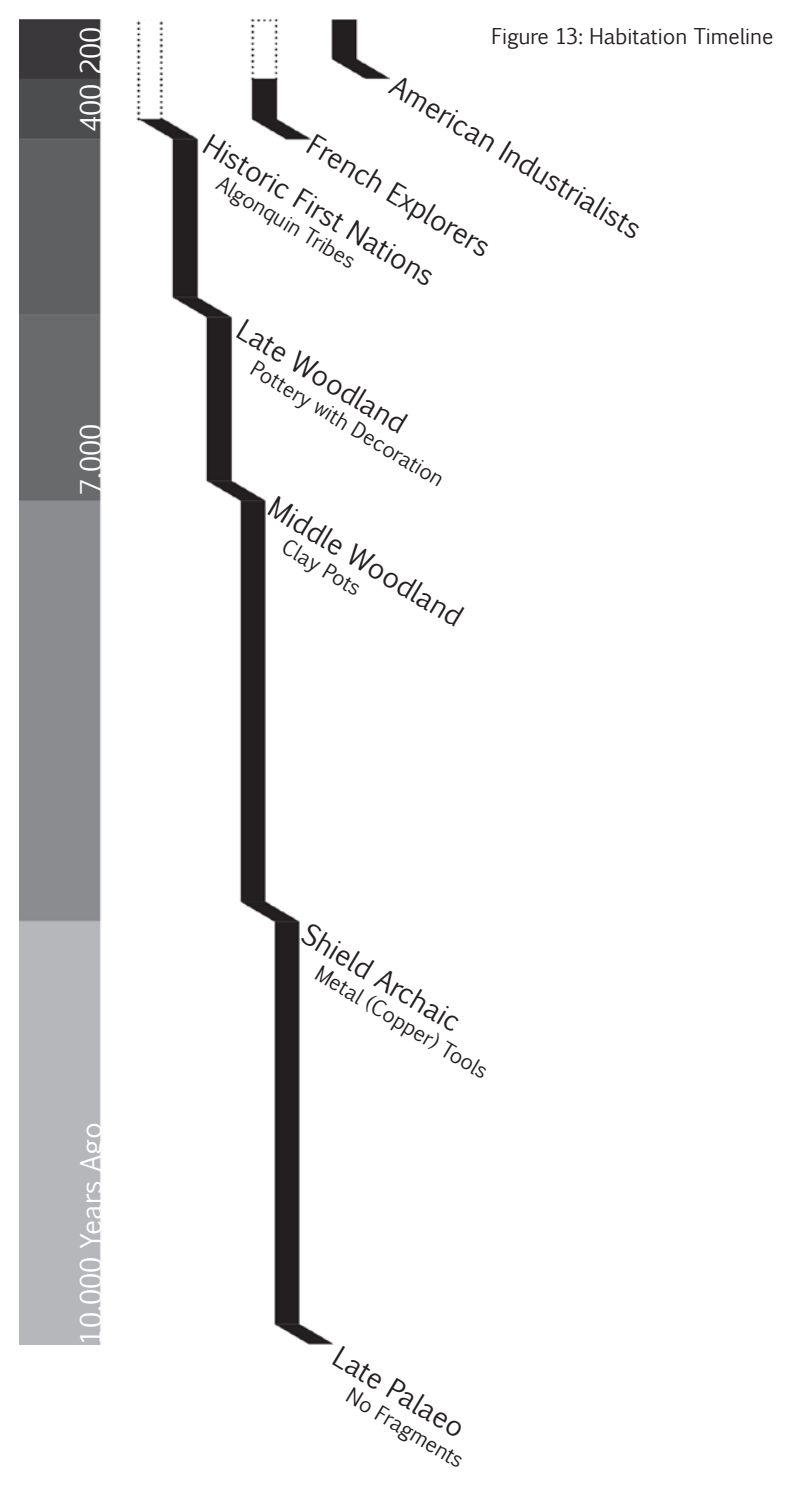

The Ottawa River was originally known as "Kit-chisippi" or "Great River" to the Algonquin people. When French Explorers canoed up the river they called it "La Riviere des Algonquin" or to some of the old-time lumberman "The Grand River". The name finally evolved to be known as "The Ottawa River". ${ }^{45}$

Lastly the Chaudière Falls designation is also derived from the Algonquin people. They called it "Asticou" which means "boiler" or "kettle". The French equivalent is "Chaudière" ${ }^{46}$ Similar to most aspects of the region the names of these important markers have also evolved from the natives of the area.

The indigenous population goes back 10,000 years ago and is divided into five different periods: (Figure 13) Late Palaeo (circa $8,000-6,000$ BC), Shield 


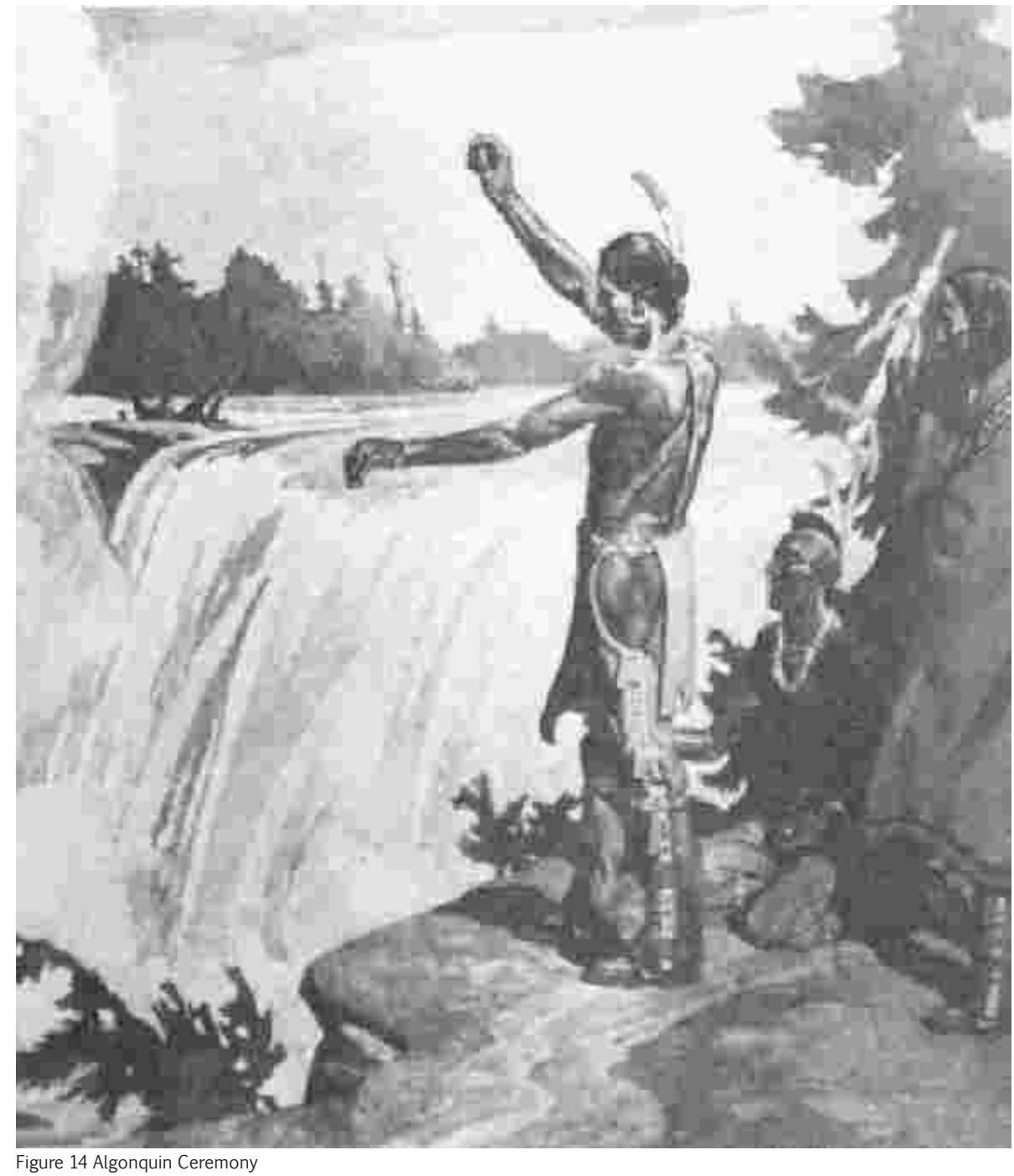

Archaic (circa 6,000 - 500 BC), Middle Woodland (circa 500 BC - AD 1200), Late Woodland (circa AD 1200 - AD 1600) and Historic (circa AD 1600 - present). These groupings are classified based off the artifacts that have been discovered in archeological sites. $^{47}$

The group of indigenous people that the French Explorers interacted with at the Chaudière Falls were the Algonquin people. They found the area to hold spiritual meaning as it was in this location that they stopped to pay respect to the Manitou, or spirit of the water. ${ }^{48}$ (Figure 14) Samuel de Champlain witnessed a ceremony and described it as follows:

"After collecting a number of pieces of smoking tobacco, a dance followed around the tribute thus 


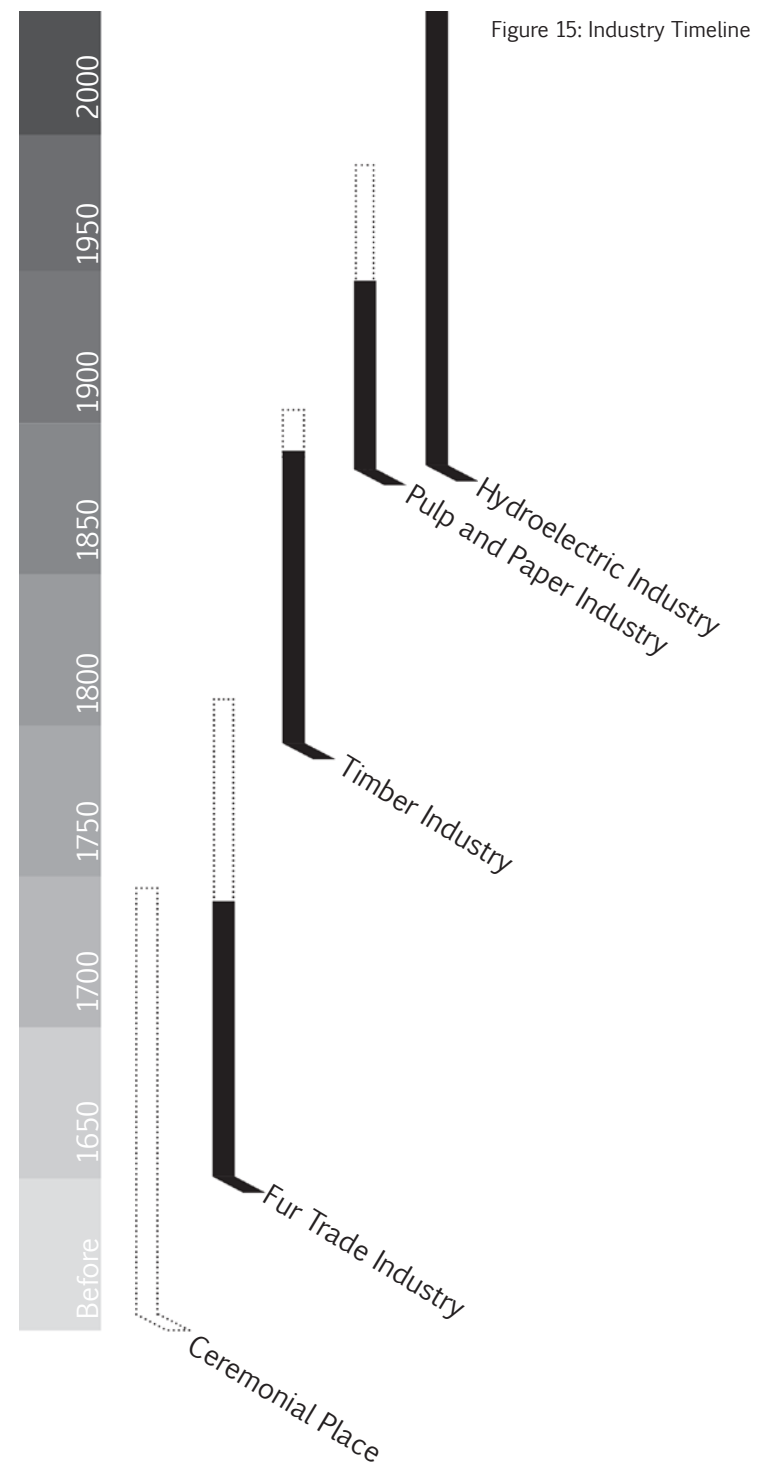

gathered, with appropriate songs in fine style. Then a captain made a warm speech, explaining the ancient and revered custom by which their ancestors had secured the protection of the Manitou against all evils, and especially their enemies a statement open to doubt. Next, advancing towards the foaming Asticou, in great solemnity they threw the tobacco over the bubbles, and raised a loud howling, and then returned to their canoes." 49

The Chaudière Falls area held an important role in the early way of life, it acted as a transportation route, which was later embraced by the explorer, fur trader, and missionary. It was through this corridor that many travelled further west and north. ${ }^{50}$ (Figure 15) 


\section{Greater Context 2.2:}

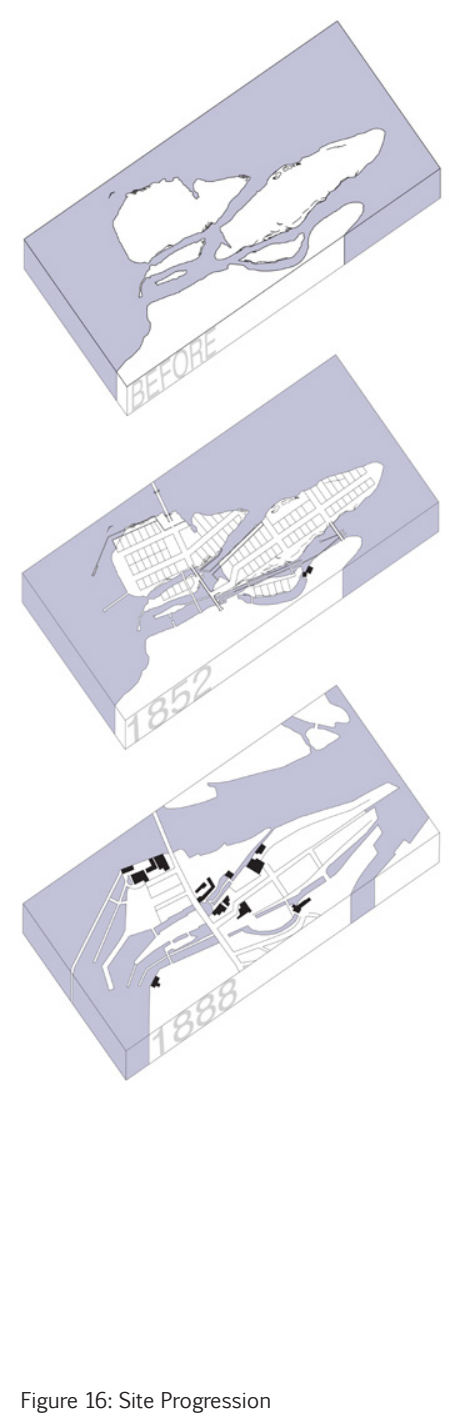

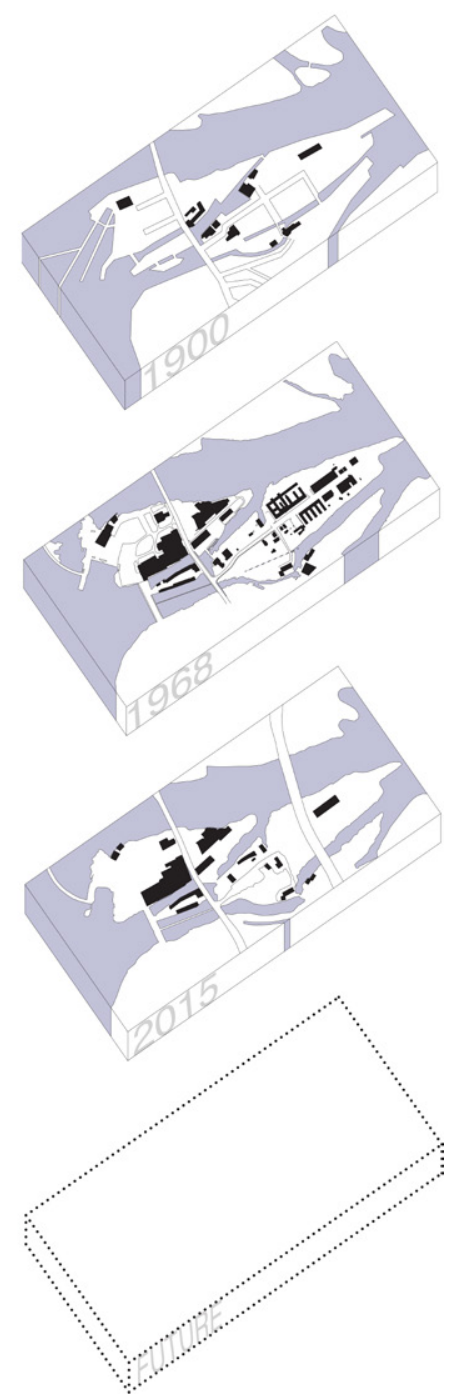

The tangible exploitation of the Chaudière Falls began in the 1800s. The area was realized to hold various industrial possibilities and over the next 150 years saw many changes in the use of the area. (Figure 16) This potential was first realized by a number of American families, the first of these being Philemon Wright, who successfully built a raft made of squared timbers and sent it down the river to Quebec City. ${ }^{51}$ Other notable events during the early days of the industrial development include: The first sawmill and gristmill built in 1808 , the first timber raft slide created in 1829 , with a second on Victoria Island in 1835, and a third in 1845 by the government. $^{52}$ (Figure 21)

The real industrial boom occurred following the 1852 plan when the Government procured all of the 


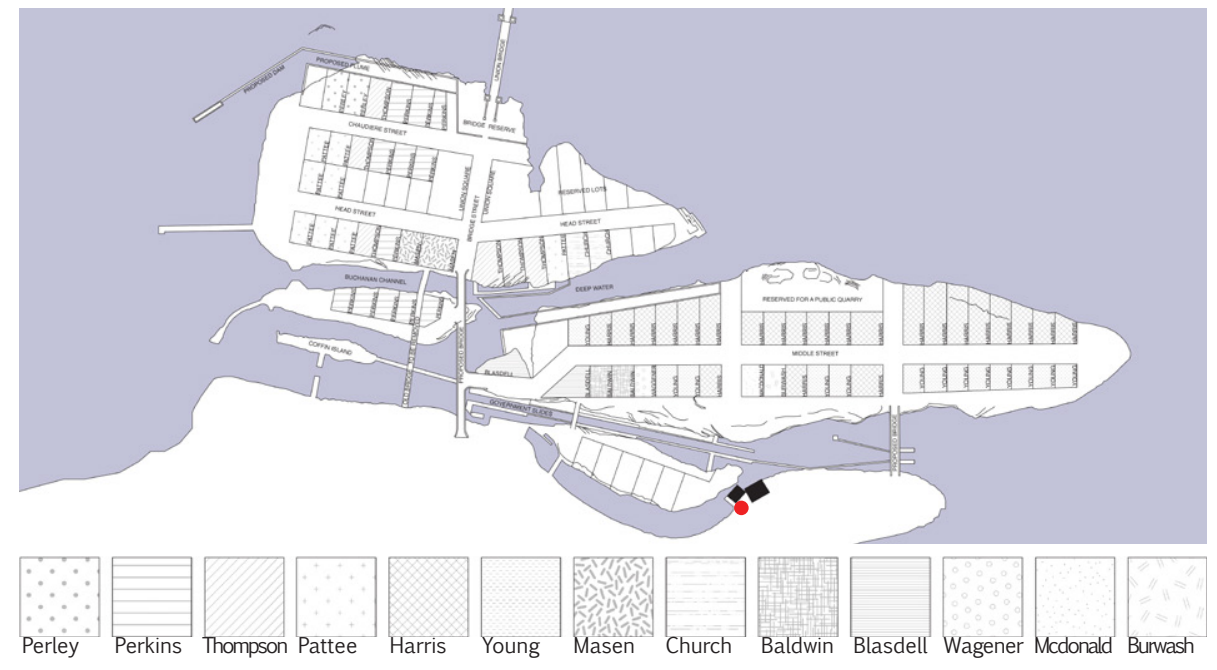

Figure 17: 1852 Plan for the Chaudiere Island and Victoria Island land on and surrounding the islands. (Figure 17) These lots were known as "hydraulic lots" meaning all had water access. Various steps were undertaken to insure that water was always available to these lots including the use of dams and log flumes. ${ }^{53}$

The industry continued to produce timber for the majority of the remaining 1800s. As the industry began to wane the lumber barons started to look to other types of business ventures. (Figure 15) The first pulp and paper mill appeared in 1886 with numerous others following in the next 30 years. ${ }^{54}$ The final major industry to be utilized at the Chaudière Falls was hydroelectric power. Very early on in the islands development, waterwheels and turbines were used to run the sawmills. The largest change in hydroelectric power occurred in 1909 with the 


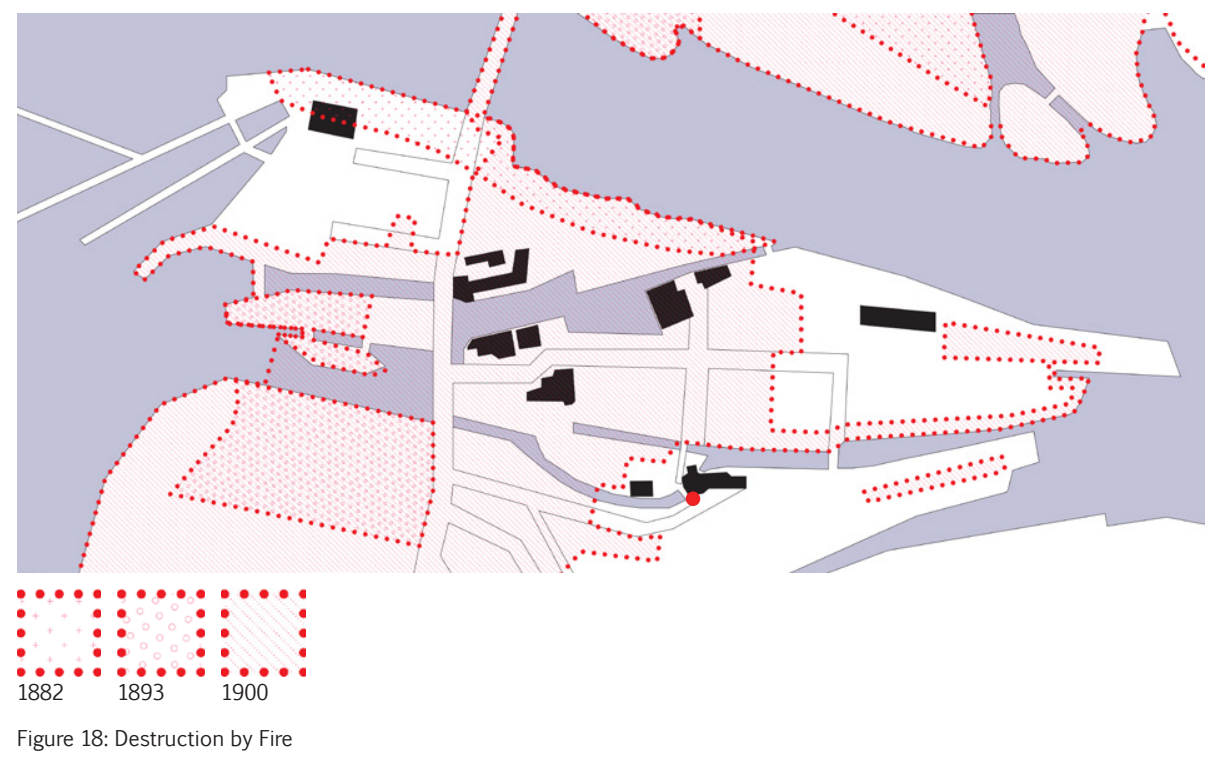

construction of the Chaudière Dam. ${ }^{55}$

The major catalyst in the change from timber mills to paper and pulp mills occurred in the form of a disaster for the Ottawa area. Continuously plagued by small fires the area was in a constant state of rebuilding. The largest of these fires occurred in 1900. Known as "the great fire" it started in Hull, crossed the Chaudière Bridge and made its way into Ottawa.

${ }^{56}$ The only portions on the islands to be saved were located where stacks of lumber were not sitting. (Figure 18) 


\section{Surrounding Context 2.3:}

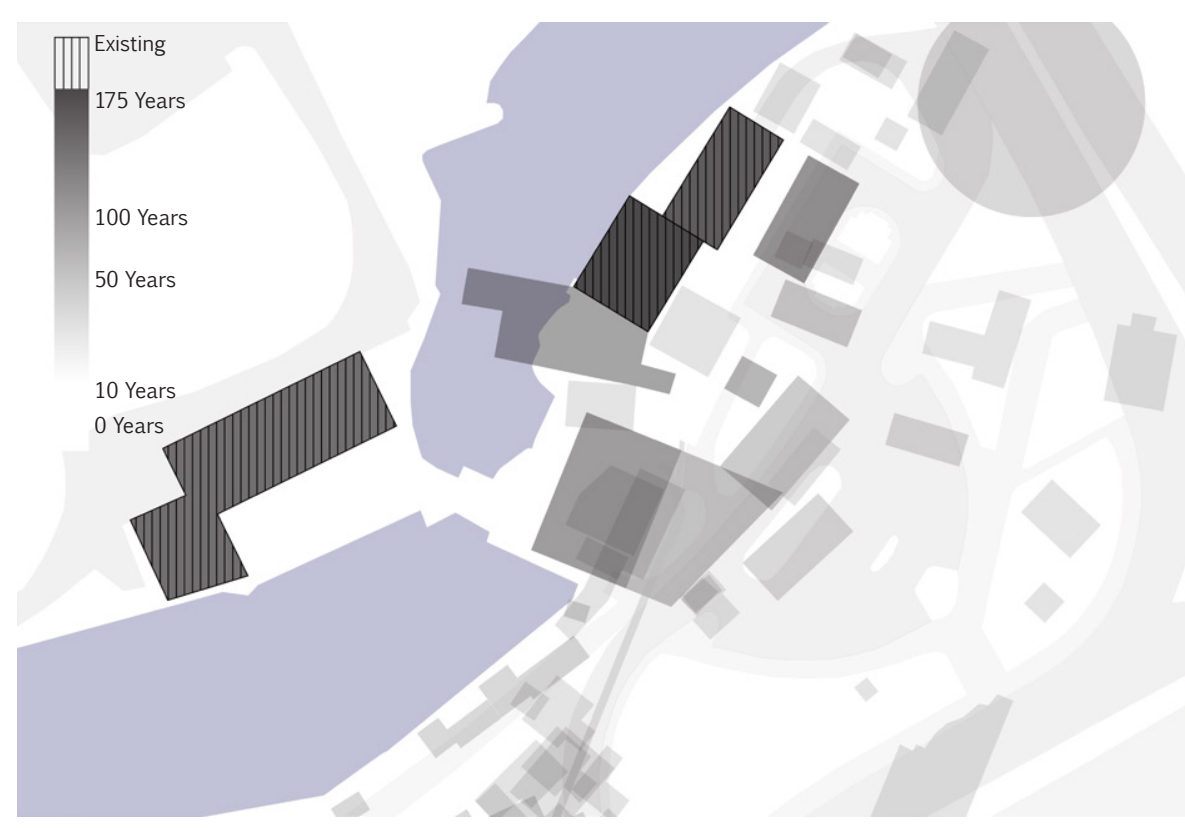

Figure 19: Industrial Evolution of the Surrounding Context
The surrounding context of the Bronson Pulp Mill focuses on the buildings located on Amelia Island and Richmond Landing. This is a location that has seen many changes over the years. (Figure 19) Multiple buildings have been associated with the site, including the Thompson Perkins Grist Mill, built in 1842 (Figure 25) with an addition added in 1851 (Figure 26), the Thompson Saw Mill was built in 1842, and the Bronson Pulp Mill built in $1912 .{ }^{57}$ Of these buildings only the Thompson Perkins Mill is remaining in

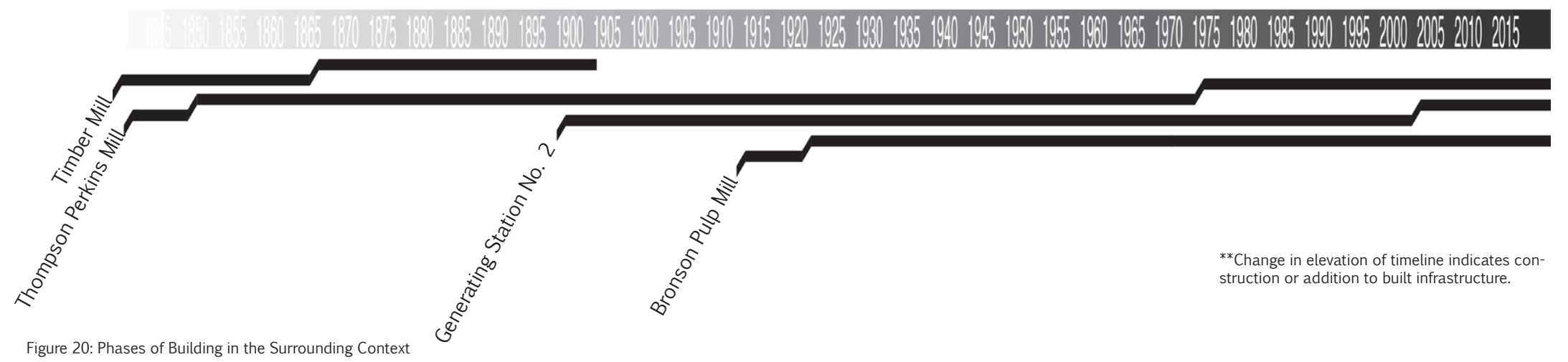




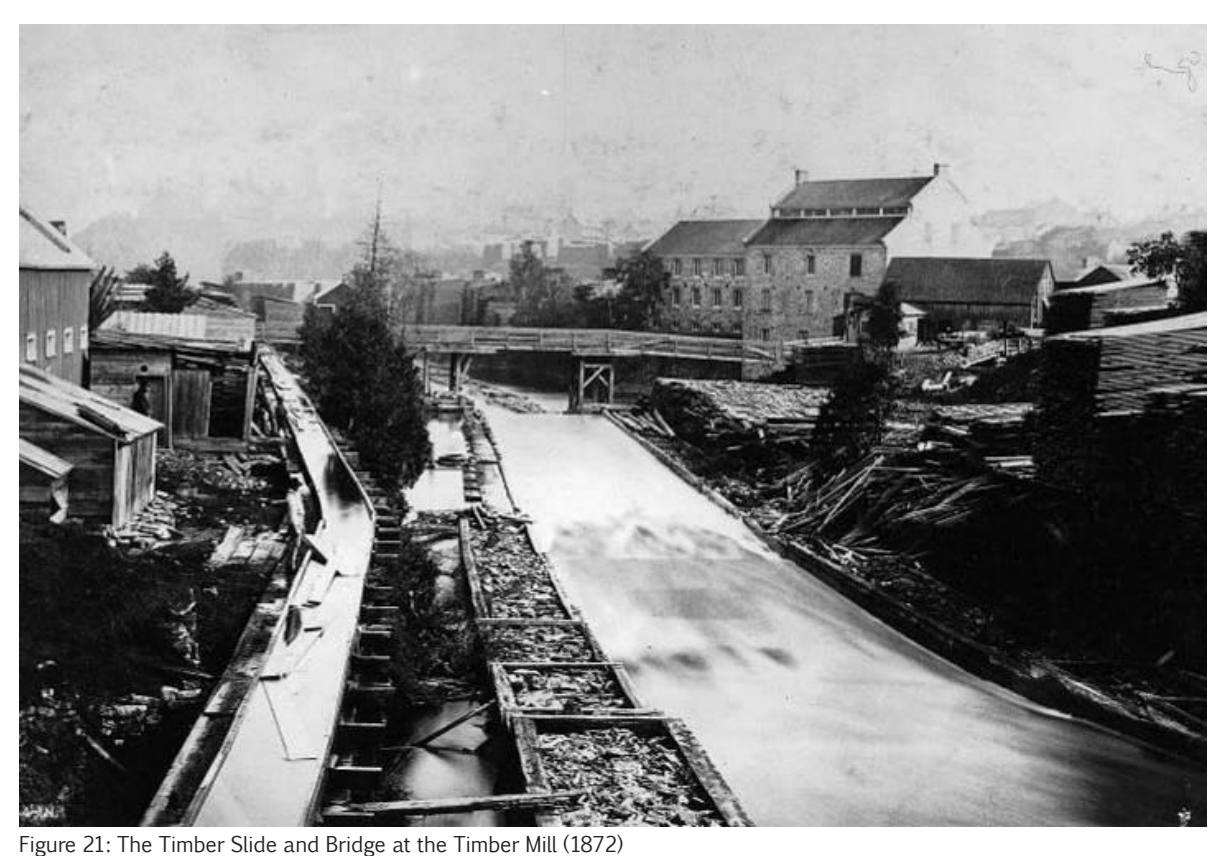

Figure 21: The Timber Slide and Bridge at the Timber Mill (1872)

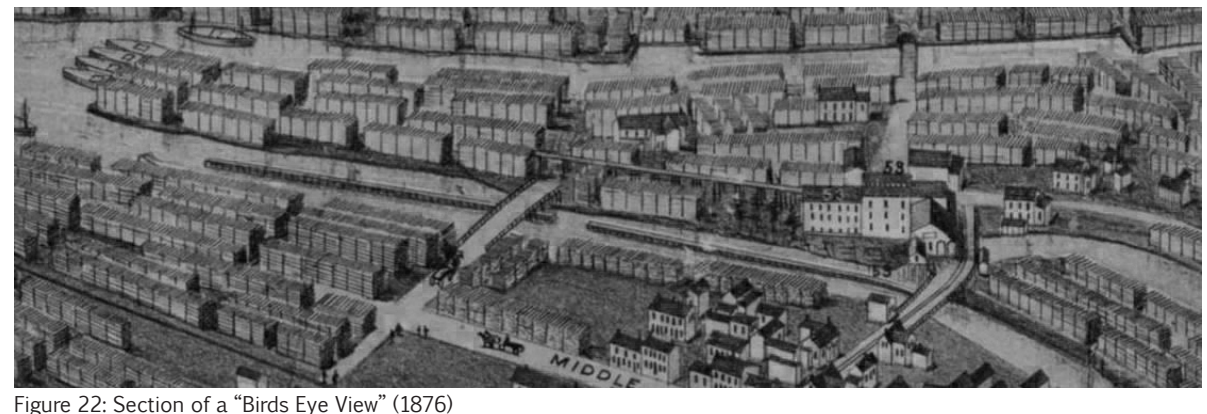

its entirety, with remnants of the Bronson Pulp Mill also existing. Generating Station No. 2 (Figure 24) is situated opposite on Amelia Island and was built in 1891. (Figure 20) The portion of the river that runs between the two is known as the Bronson Channel and was harnessed by the various buildings located along it..$^{58}$ To cross the channel there were two separate bridges incorporated into the infrastructure, a platform associated with the timber mill from 1866 and removed when the mill was demolished, and a wooden bridge from 1913-to the late 1920s. ${ }^{59}$ (Figure 21)

Various people have owned the land where the Bronson Pulp Mill was located. (Figure 23) Robert Randall purchased the land in $1809 .{ }^{60}$ He was eventually ruined after a series of bad investments and 


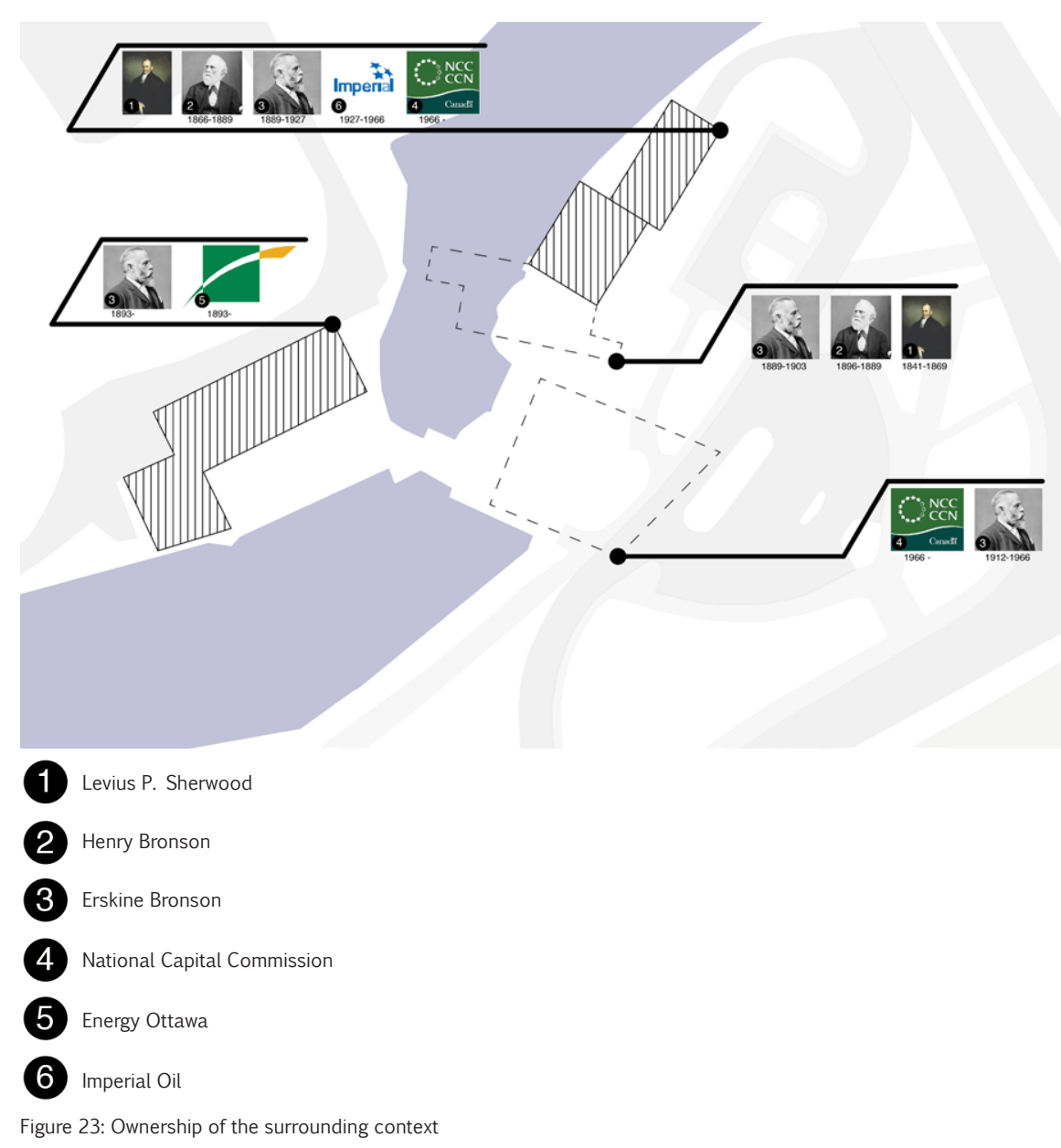

the land was sold to John Le Breton in 1820, who sold half the land to his partner Levius P. Sherwood. It was in this location that the mill sat. ${ }^{61}$ The Bronson family has owned most of the buildings surrounding the site at one time or another, they were one of the American families drawn to the area by the prospect of purchasing the hydraulic lots that had been put up for sale in 1852. Henry Bronson worked with his partner John Harris and eventually Abijah Weston to establish the Bronson and Weston Lumber Co. which became one of the largest timber companies in Canada. ${ }^{62}$ Their success was based largely off of their procurement of one of the better lots offered in $1852 .{ }^{63}$ The first Bronson Mill was built in 1852, it employed over 300 men $^{64}$ and by the 1870 s 25 million board feet were being produced annually. ${ }^{65}$ The company was eventually taken over by Henry 


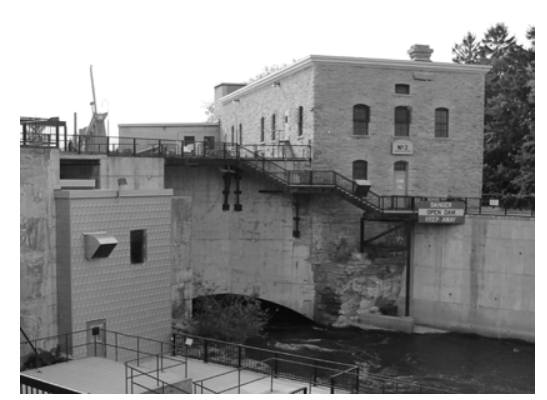

Figure 24: Generating Station No. 2 (1891)

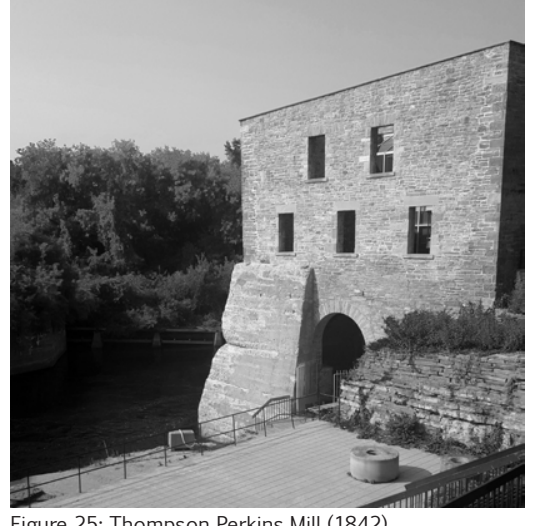

Figure 25: Thompson Perkins Mill (1842)

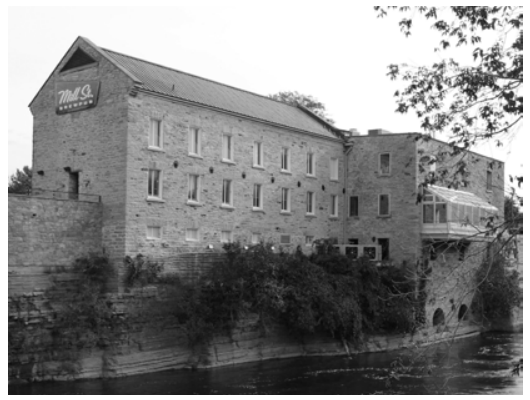

Figure 26: Thompson Perkins Mill Addition (1851)
Bronson's son, Erskine Bronson in $1889^{66}$ who renamed it The Bronson Company in $1899 .{ }^{67}$ It was under his leadership that the company branched off into supplementary enterprises other than lumber. These included: pulp and paper, hydroelectric utilities, transportation, minerals, chemicals, gas lamps and heaters. ${ }^{68}$ 


\section{Immediate Context 2.4:}
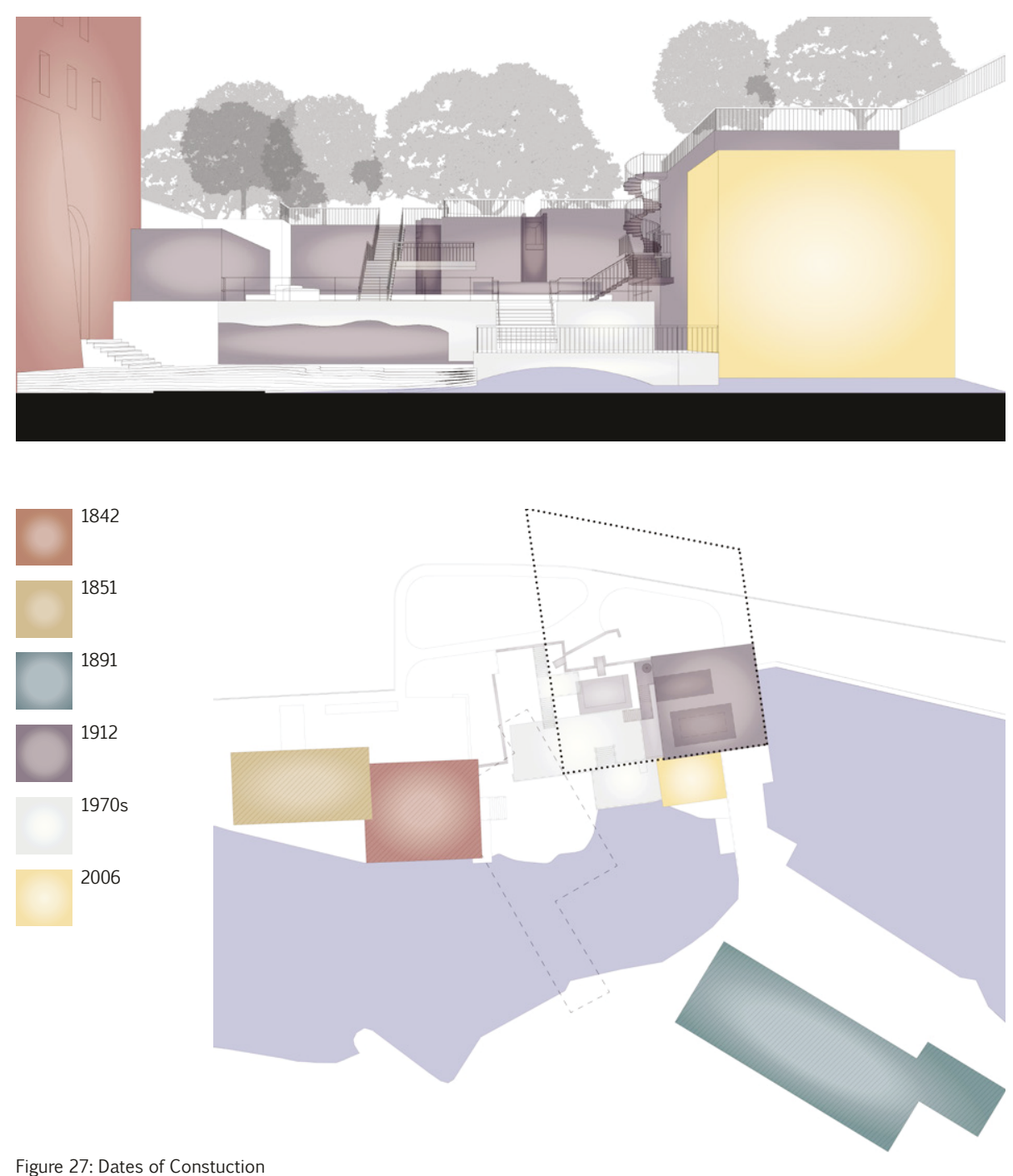

In 1903 the Bronson Company made the decision to branch into other industries and build a pulp and paper mill. The site was chosen based on the location of the other surrounding buildings. (Figure 27) The construction of the mill would create a market for the hydro-electric power created with the Generating Station No. $2 .{ }^{69}$ This location was considered ideal because of the 33' elevation change between road level and water level, the other industrial buildings in the area, as well as the accessibility provided by the train line. ${ }^{70}$ The production of pulp in the area was considered very advantageous: the Ottawa Valley Mills produced wood pulp of a high quality, "By cutting pulpwood, it was estimated that investors could add as much as 20 percent to the value of the timber leases they leased." After extensive planning, the mill was finally built in 1912 . 

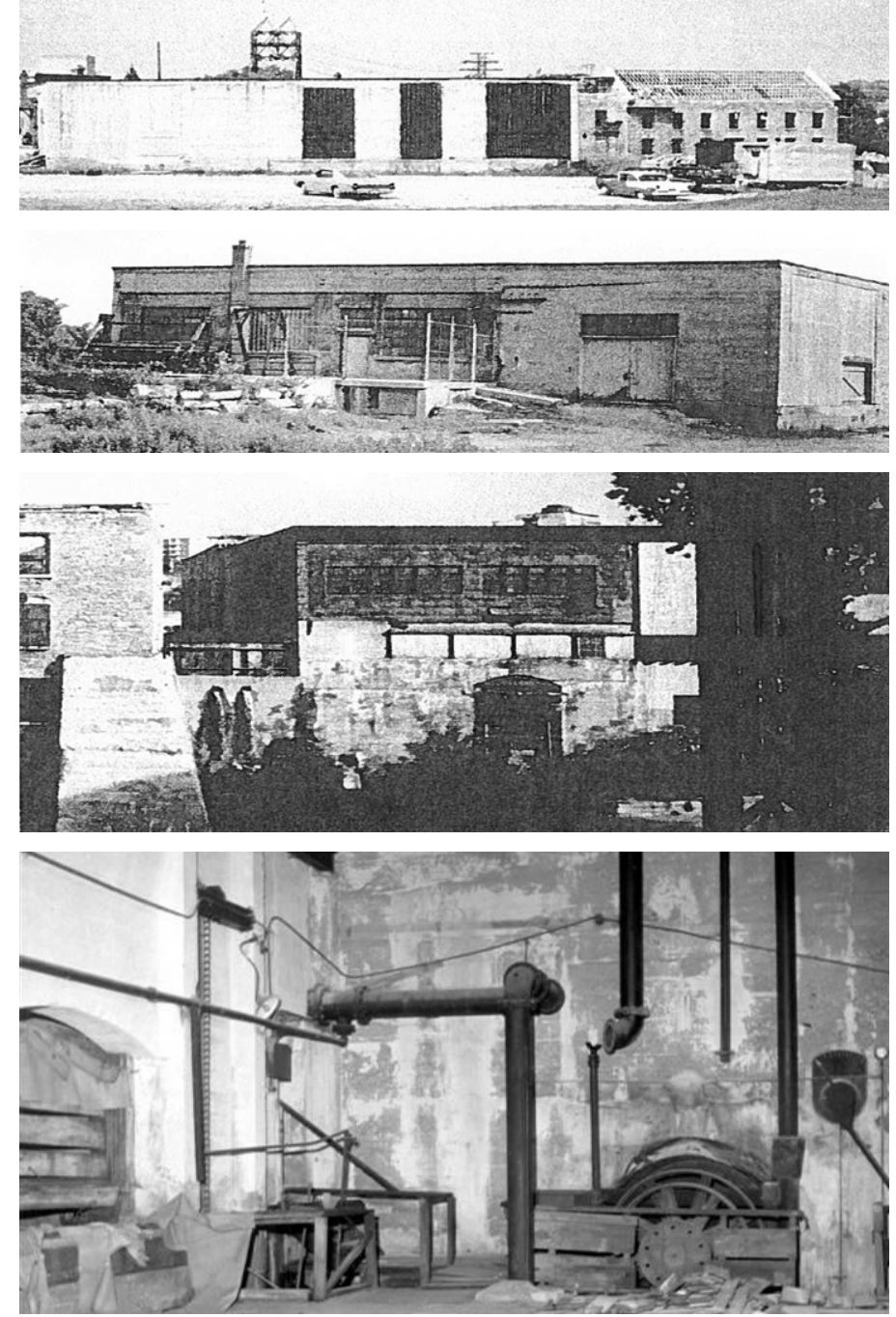

Figure 28: Original Images of the Bronson Pulp Mill
The two storey mill itself was built directly on the rock and was 97 feet by 98 feet. The building materials comprised of steel beam and non-reinforced concrete, with brick, wood, and metal siding. The foundations and lower level were comprised of reinforced concrete. The west portion of the building acted as part of the bulkhead of the Bronson Channel. The north façade had a large archway similar to the arch in the Thompson Perkins Mill. ${ }^{71}$ (Figure 28)

Following a decline in the pulp industry the Bronson Pulp Mill ceased operations in the early 1950s and sat empty for many years. ${ }^{72}$ In 1968 it was sold to the NCC who had plans to create a renewal of the area. It was then demolished and is now a stabilised ruin. ${ }^{73}$ 


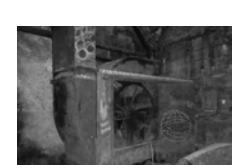

Furnace

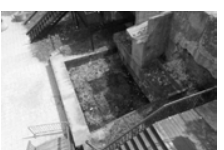

Holding Basin

Log Chutes

Grindstones
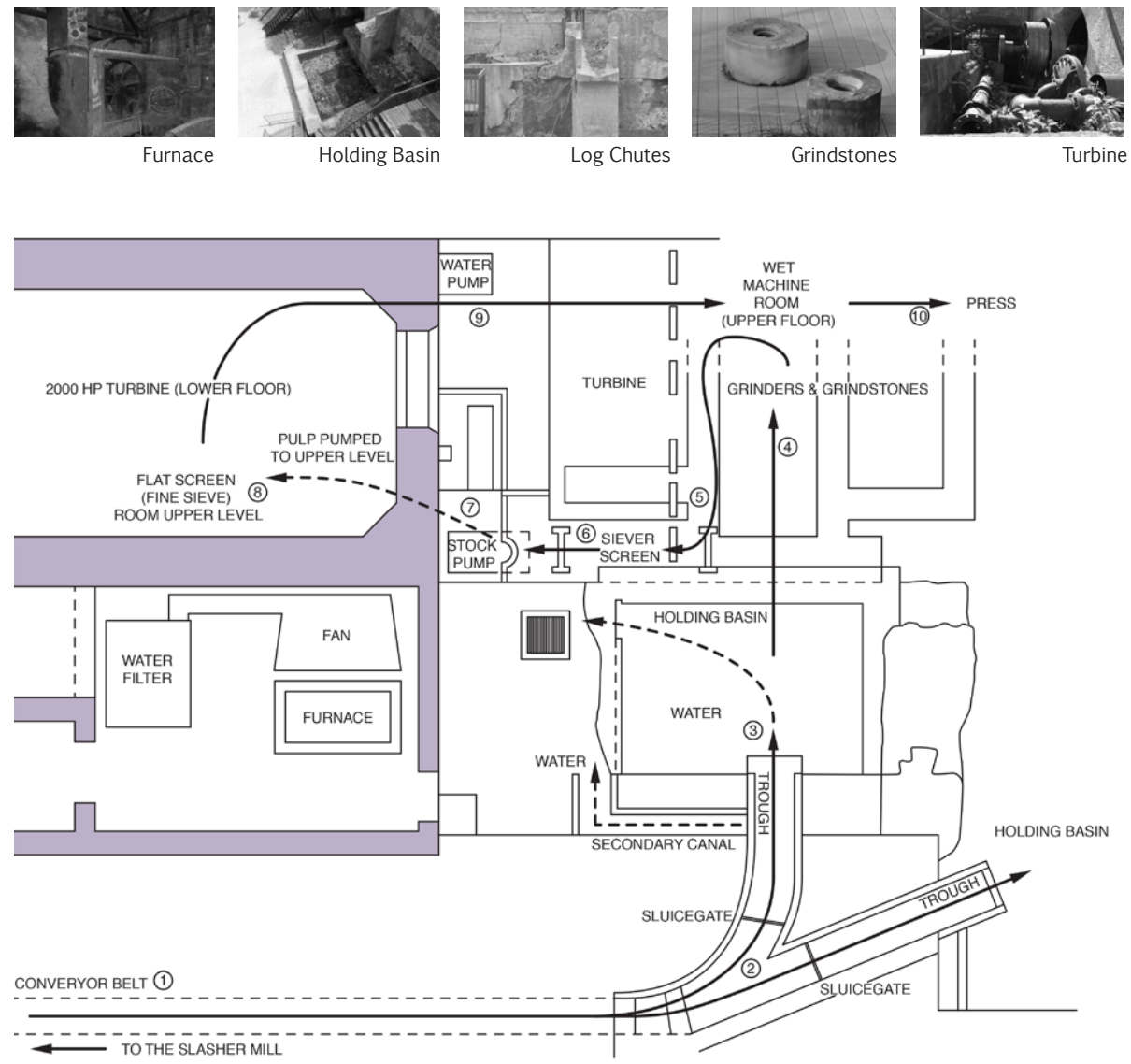

Figure 29: How the Pulp Mill Functioned
The Bronson Pulp Mill was a functional mill within the Canadian paper and pulp industry which in the 1920s was one of the greatest in the world. This importance is due to the vast resources that were available, including the forestry and hydroelectric industries. ${ }^{74}$ There are two methods of converting wood into pulp and paper: the mechanical method and the chemical method. The Bronson Pulp Mill utilized the mechanical method of making pulp. Mechanically made pulp is not suitable for finer grades of paper as it contains only 55 percent cellulose. Cellulose is the crucial ingredient in paper and the "chemical" method results in pure cellulose. This difference in the cellulose means that with the mechanical method the fibres are shorter and stiffer causing them to not interlace correctly, mechanical pulp is often mixed with chemical pulp to solve this issue. ${ }^{75}$ 
The process begins by cutting down the tree. This can happen at a great distance from the mill, and the tree will need to be transported to the site. The location of where the tree is felled means it will either be floated down a river, or transported by rail. ${ }^{76}$ Once the tree has arrived at the mill the bark must be removed, as this portion of the tree has insignificant fibre value and takes up valuable resources in the pulp and paper production. ${ }^{77}$ The removal can be done through the use of two different machines: the tumbler or the barker (also known as the rosser). With the use of the tumbler 2 foot long logs are put into a cylindrical drum, with water. The drum then rotates and the logs hit against each other and the sides of the drum and remove the bark. With the use of the barker a heavy iron disk rotates, attached are knives that shave the bark off. ${ }^{78}$ 

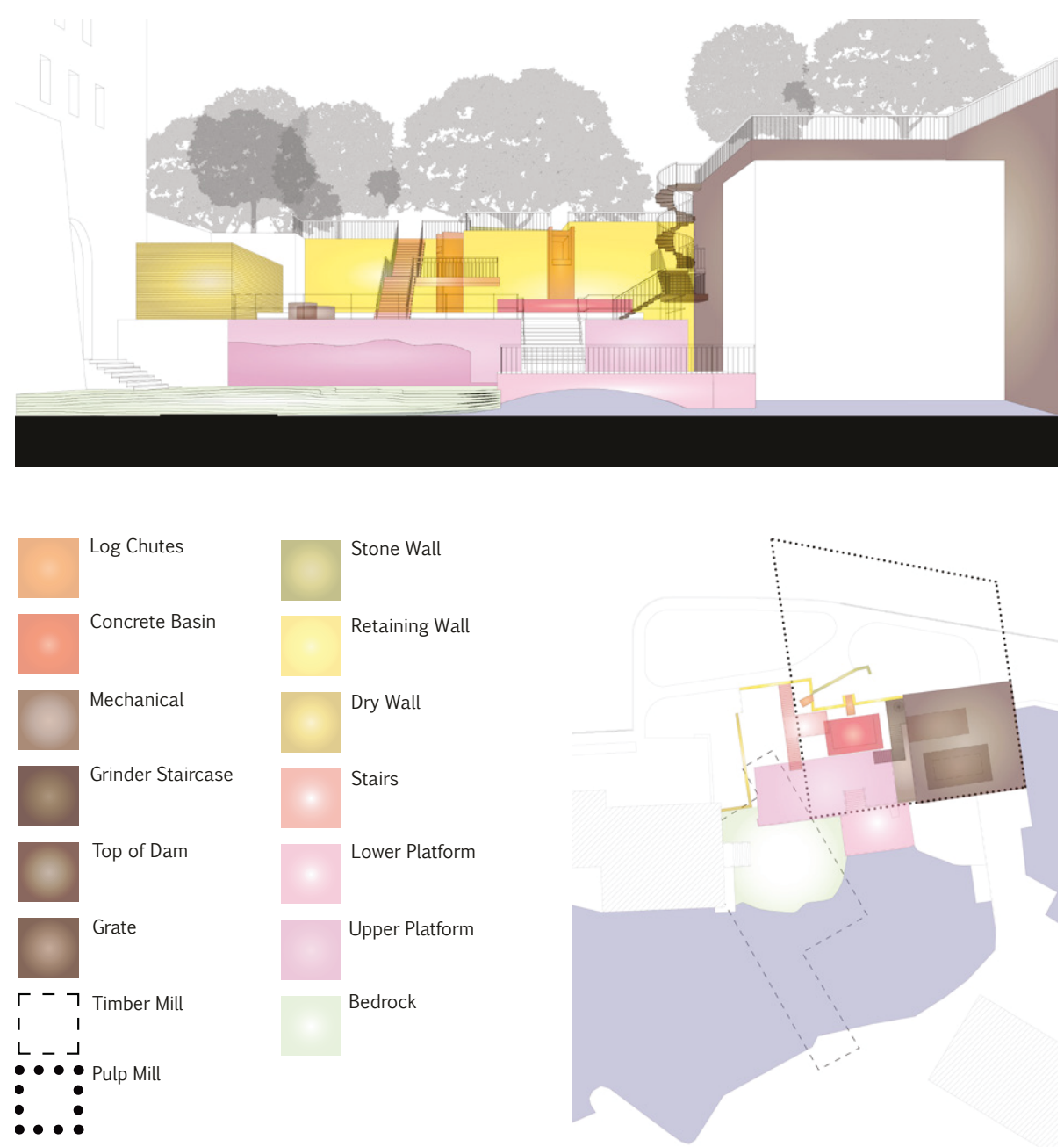

Figure 30: Classification of Character Defining Elements
To make mechanical pulp (Figure 29) pieces of wood are applied to a large grindstone using hydraulic pressure. The ground wood then takes the form of slush and is screened to remove leftover large portions. $^{79}$ The slush is now ready to be made into pulp or paper. If the paper mill is in the vicinity, the slush can be moved using pipes without converting it into pulp. If it has to travel a distance the slush is condensed until 30 to 50 percent of water in removed. ${ }^{80}$ It is at this stage that the pulp can be pressed into paper.

Following the deconstruction of the Bronson Pulp Mill in 1968, a number of elements were left as a stabilised ruin. (Figure 30 ) This stabilisation implied that the general public would be allowed access to the site. 

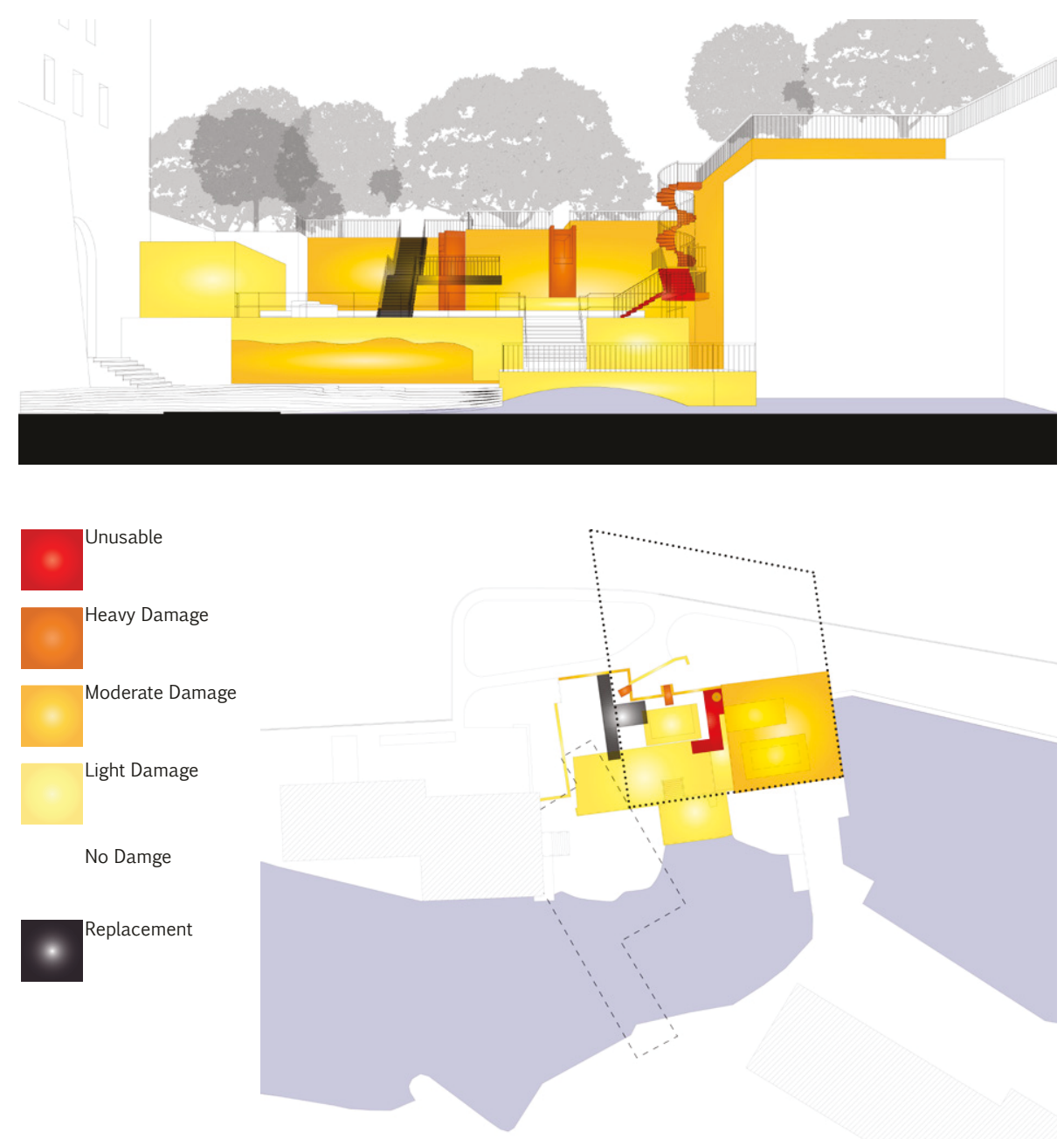

A structural analysis was undertaken in 2015 by HP Engineering, a firm located in Ottawa. The examination included looking at the current state of all of the elements and recommendations on how the level of deterioration and damage can be fixed to allow safe access to the site. (Figure 31) 


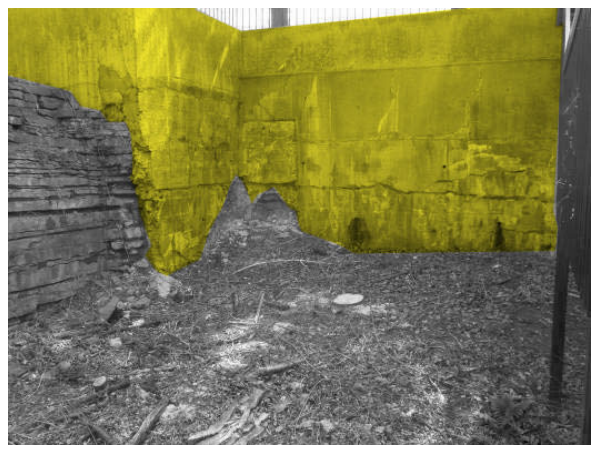

Figure 32: East Portion of the South Concrete Retaining Wall

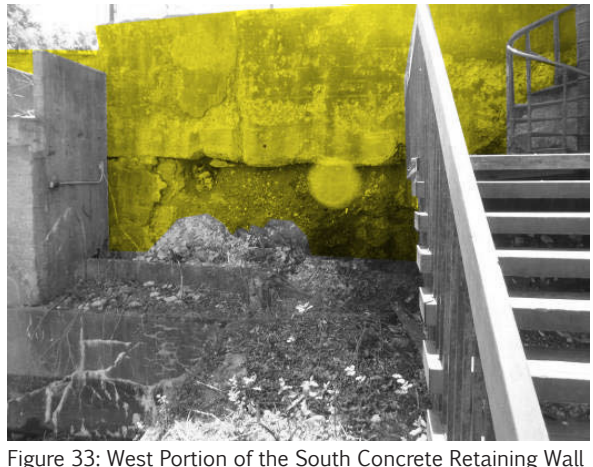

Figure 33: West Portion of the South Concrete Retaining Wall

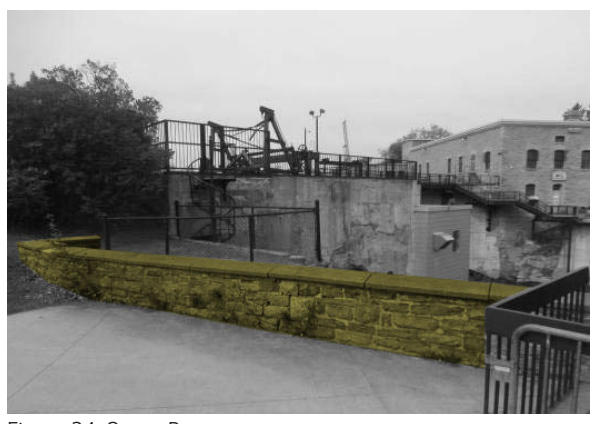

Figure 34: Stone Parapet

\section{The South Concrete Retaining Wall}

The wall extends from the grinder room at the west, and the dry stone wall to the east with the parking lot to the south and canal to the north. The wall is constructed against bedrock and is separated by the log chute. ${ }^{81}$ Damages include spalling, scaling, water leakage, cracking and delamination.

Recommendation: the entire wall needs to be refaced, with the cracks filled with grout and epoxy injections. Drainage will need to be improved as leakage of groundwater is occurring. ${ }^{82}$

\section{The Stone Parapet}

The parapet is located south of the log chutes, and is constructed of grouted stone masonry. The wall is in good condition other than slight mortar cracking and a few loose stones, with one missing precast coping section. ${ }^{83}$

Recommendation: Securing and repointing of the loose stones, and replacement of the missing coping. ${ }^{84}$ 


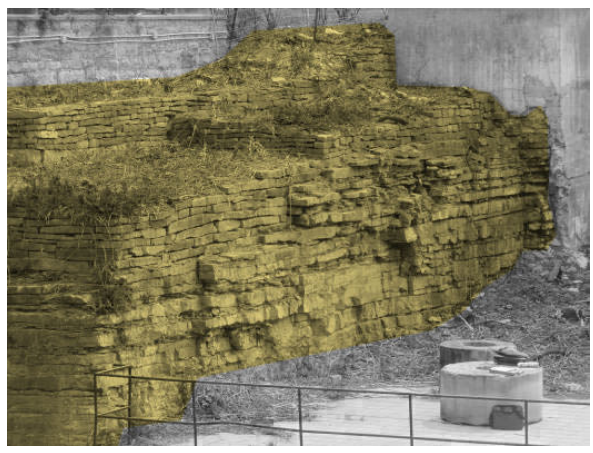

Figure 35: Dry Stone Wall

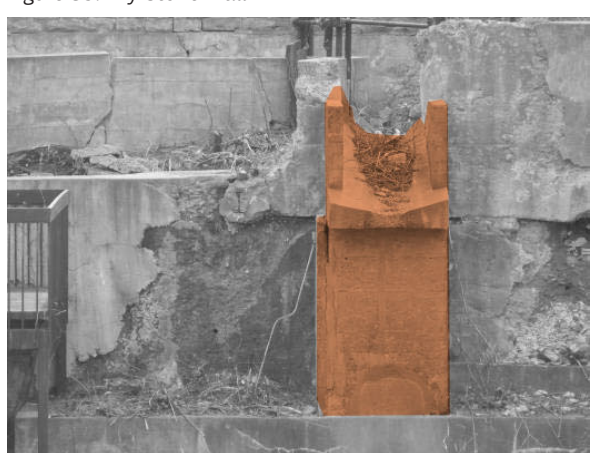

Figure 36: Concrete Log Chutes

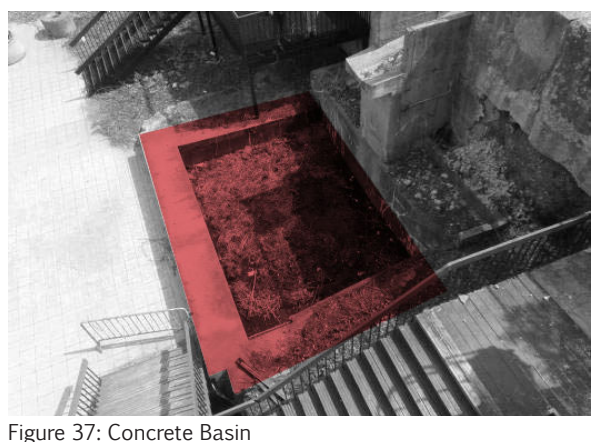

The Dry Stone Wall

The dry stone retaining wall is in good condition with narrow vertical cracks and some protruding loose rocks. 85

Recommendation: Face of the wall should be scaled removing loose and protruding stones. Stabilization through grouting may also be required. ${ }^{86}$

\section{Concrete Log Chutes}

The concrete log chute has portions broken off, with scaling delamination and large spalls. The start of the tunnel could not be determined. ${ }^{87}$

Recommendation: The sections of the wall that are broken off need to be replaced with a new concrete structure. The scope of the tunnel will need to be determined. ${ }^{88}$

\section{Concrete Basin}

The concrete basin is located at the base of the concrete log chute. It has minimal cracking and slight efflorescence on the interior faces. The construction of the bottom of the basin is unconfirmed. ${ }^{89}$ Recommendation: Repair of the cracking structure. ${ }^{90}$ 


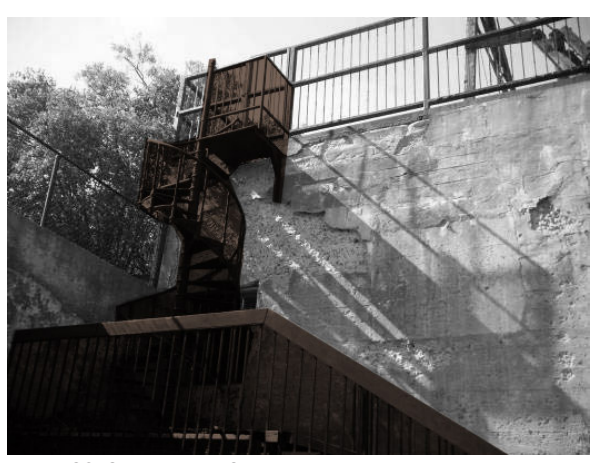

Figure 38: Staircase to Grider Room and Roo

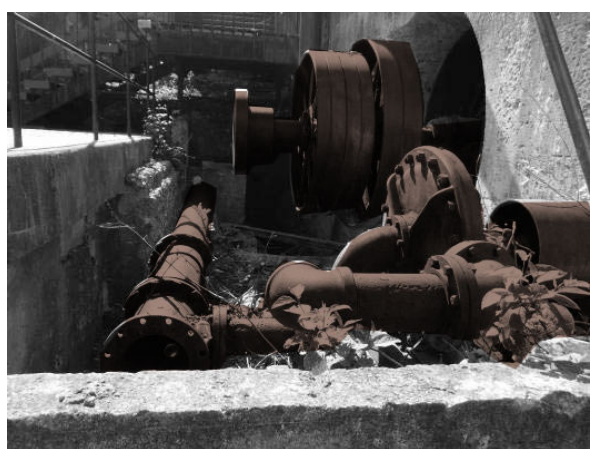

Figure 39: Turbine

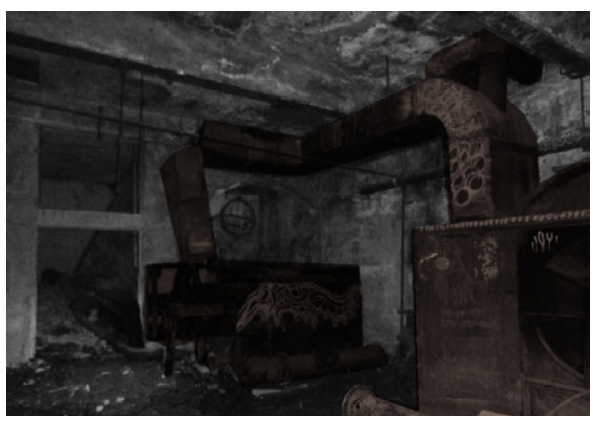

Figure 40: Furnace
Staircase up to Grinder Room Entrance and Roof

The staircase is made up of two portions: the lower wooden portion and the upper cast iron spiral stair. The timber treads and landings are rotten, and are connected to steel stringers. The spiral stairs is in poor condition which is caused by cracking. ${ }^{91}$

Recommendation: The lower staircase will need to be replaced, and the upper spiral stair is in need of refurbishment. ${ }^{92}$

The Mechanical Equipment

Various types of mechanical equipment are remaining including: existing turbine, ductwork, a water pump, a disconnected cast iron pipe, a disconnected pipe and pulley wheels on the power transmission shaft for the existing turbine penetrating the wall. All of these components have various levels of corrosion. ${ }^{93}$

Recommendation: Refurbishment of components will need to occur. ${ }^{94}$ 


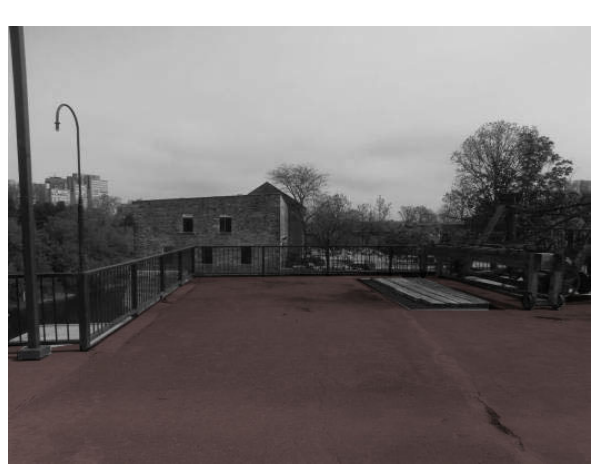

Figure 41: Dam Deck and Grinder Room Roof

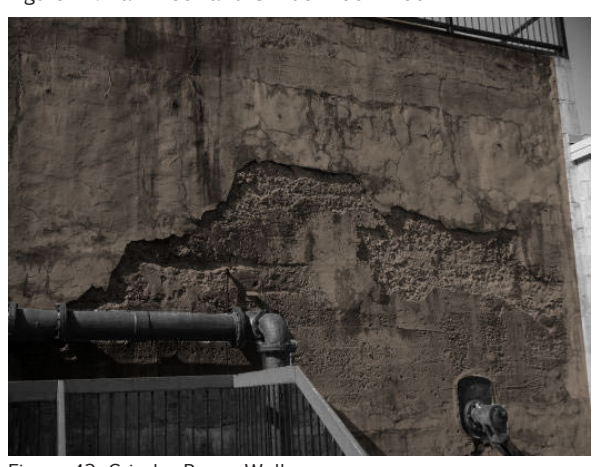

Figure 42: Grinder Room Wall

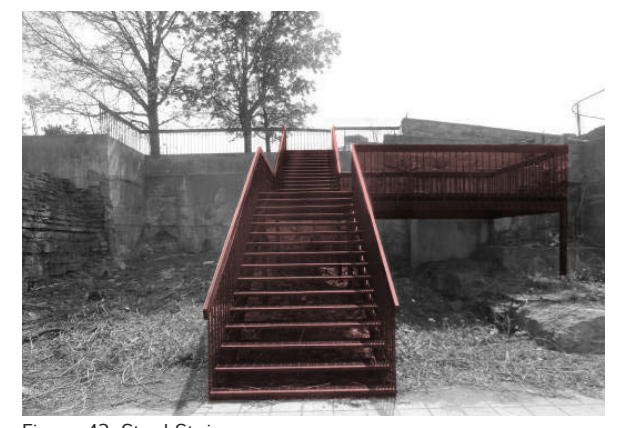

Figure 43: Steel Staircase

\section{The Dam Deck and Grinder Room Roof}

The roof has light to moderately corroded steel beams in the slab, the grate is in good condition with a number of missing fasteners. ${ }^{95}$

Recommendation: A structural evaluation will be required of the roof and wall structures, as well as the repair of the grate fasteners. ${ }^{96}$

\section{Grinder Room}

Delamination of around 40 percent and scaling of 50 percent has occurred on the wall face. A turbine unit is attached to the east portion of the wall, with a door located on the same face. ${ }^{97}$

Recommendation: Resurfacing of the entire wall to repair the spalls and cracks. The steel gate at the door location will need to be replaced..$^{98}$

\section{Steel Staircase}

This staircase is composed of steel stringers and beams, which are supported by the steel HSS columns. The landing and treads are comprised of steel grating. ${ }^{99}$ 


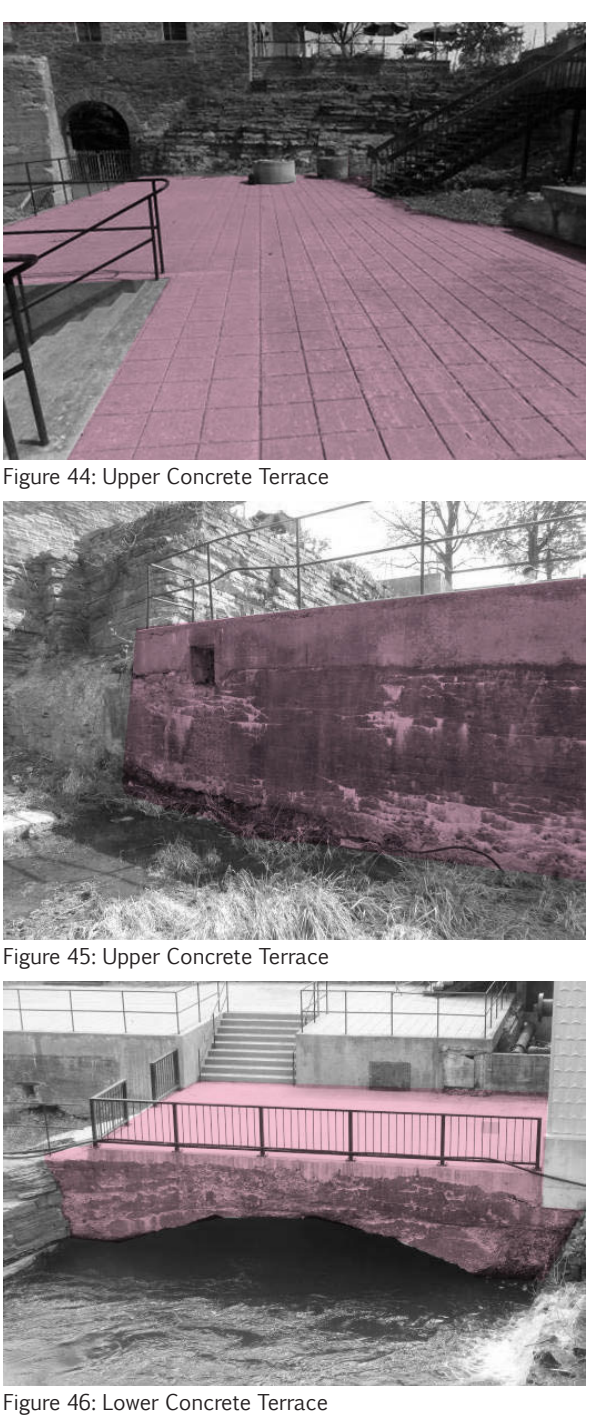

Traces of the Past: Interpretation \& Dissemination

\section{Upper Concrete Terrace}

The upper concrete terrace is located directly on top of the foundation of the ruins. It has 3 tunnels exiting the north face. It is comprised of cast-in-place concrete slab with a stamped surface. ${ }^{100}$

Recommendation: The concrete spalls and scaling are in need of repair, leaking appears to be ground water, and the source will need to be determined. ${ }^{101}$

\section{Lower Concrete Terrace}

The lower terrace is also cast-in-place concrete located at the river level. The face of wall by the river has severe scaling. ${ }^{102}$

Recommendation: Construction of the surface will need to be determined. Further exploration of the tunnel will need to take place. ${ }^{103}$ 


\section{Tangible Context 2.5:}

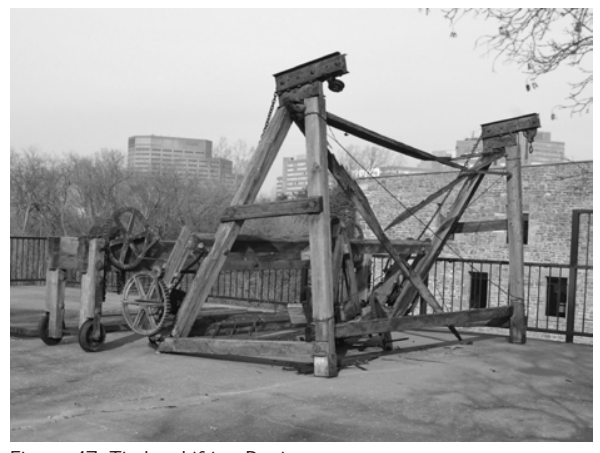

Figure 47: Timber Lifting Device
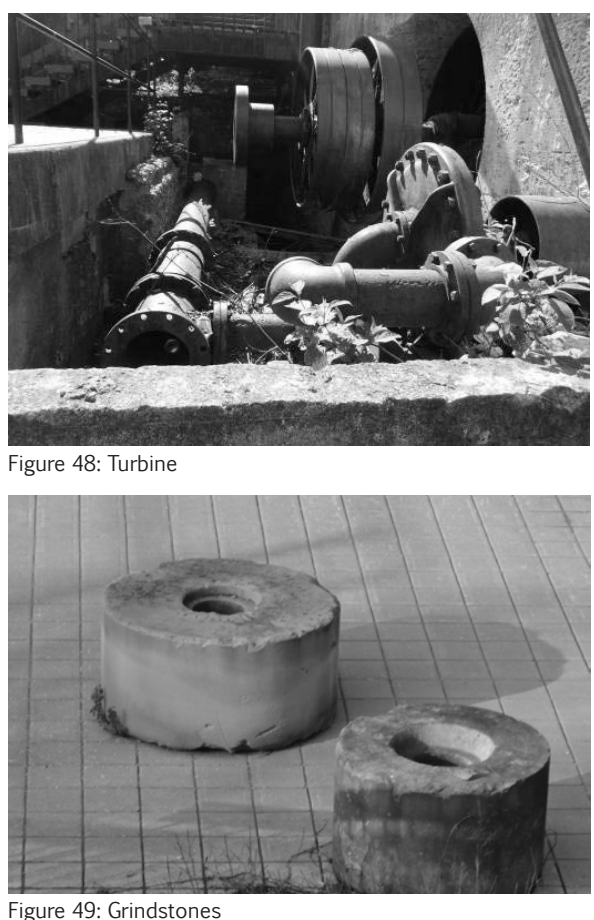

The Bronson Pulp Mill ruins have a number of arti-

facts located in situ that are still connected to their original infrastructure. These include a furnace and strainer apparatus which was used to process the pulp. The turbine, belt driven pumps, and incomplete portions of the cast iron piping still attached to the wall. A cast iron staircase is located in a similar position to where it originally stood. A wooden stop log crane is positioned on the top of the dam; this was used to control water into the turbine room. Finally there are two grindstones on the surface of the upper terrace. There is also the built infrastructure around the site including, the log chutes and holding basin. 


\section{Endnotes Part 2:}

34. Larkham, PeterJ, and Gunila Jiven "Sense of Place, Authenticity and Character: A Commentary". Journal of Urban Design, Vol. 8, No. 1, 67-81, 2003. 68

35. "Earthquake Zones in Eastern Canada." Stephen Halchuk, Jim Lyons. Government of Canada, 26 Apr. 2013. Web. 04 Nov. 2015. <http://earthquakescanada.nrcan.gc.ca/ zones/eastcan-eng.php>.

36. Bond, Courtney C. J, and Robert U. Mahaffy. Where Rivers Meet: An Illustrated History of Ottawa. Woodland Hills, CA: Windsor Publications, 1984.11.

37. Bond, Courtney C. J., and Robert U. Mahaffy. Where Rivers Meet: An Illustrated History of Ottawa. Woodland Hills, CA: Windsor Publications, 1984.11.

38. QLFCanada, comp. A Background Study for the Nomination of the Ottawa River Under the Canadian Heritage Rivers System. Publication. Petawawa: Canadian Heritage Rivers System, 2005. 161

39. QLF Canada, comp. A Background Study for the Nomination of the Ottawa River Under the Canadian Heritage Rivers System. Publication. Petawawa: Canadian Heritage Rivers System, 2005. 162

40. QLFCanada, comp. A Background Study for the Nomination of the Ottawa River Under the Canadian Heritage Rivers System. Publication. Petawawa: Canadian Heritage Rivers System, 2005. page 163

41. QLFCanada, comp. A Background Study for the Nomination of the Ottawa River Under the Canadian Heritage Rivers System. Publication. Petawawa: Canadian Heritage Rivers System, 2005. 163

42. QLFCanada, comp. A Background Study for the Nomination of the Ottawa River Under the Canadian Heritage Rivers System. Publication. Petawawa: Canadian Heritage Rivers System, 2005. 164

43. QLF Canada, comp. A Background Study for the Nomination of the Ottawa River Under the Canadian Heritage Rivers System. Publication. Petawawa: Canadian Heritage Rivers System, 2005.167

44. Ross, Alexander Herbert Douglas. Ottawa, past and Present. Toronto: Musson Book, 1927.9

45. Ross, Alexander Herbert Douglas. Ottawa, past and Present. Toronto: Musson Book, 1927. 2

46. Ross, Alexander Herbert Douglas. Ottawa, past and Present. Toronto: Musson Book, 1927.5

47. QLFCanada, comp. A Background Study for the Nomination of the Ottawa River Under the Canadian Heritage Rivers System. Publication. Petawawa: Canadian Heritage Rivers System, 2005.9

48. Ross, Alexander Herbert Douglas. Ottawa, past and Present. Toronto: Musson Book, 1927.7

49. Ross, Alexander Herbert Douglas. Ottawa, past and Present. Toronto: Musson Book, 1927.8
50. Taylor, John H. Ottawa: An Illustrated History. Toronto:J. Lorimer, 1986. 11

51. "The District - Vision Chaudiere." Vision Chaudiere. Web. 03 Oct. 2015. <http://Visionchaudiere.ca/the-district/>

52. "The District - Vision Chaudiere." Vision Chaudiere. Web. 03 Oct. 2015. <http://visionchaudiere.ca/the-district/>.

53. Bond, Courtney C. J., and Robert U. Mahaffy. "Where Rivers Meet: An Illustrated History of Ottawa." Woodland Hills, CA: Windsor Publications, 1984. 56.

54. QLFCanada, comp. A Background Study for the Nomination of the Ottawa River Under the Canadian Heritage Rivers System. Publication. Petawawa: Canadian Heritage Rivers System, 2005. 101

55. QLFCanada, comp. A Background Study for the Nomination of the Ottawa River Under the Canadian Heritage Rivers System. Publication. Petawawa: Canadian Heritage Rivers System, 2005. 122

56. "The District - Vision Chaudiere." Vision Chaudiere. Web. 03 Oct. 2015. <http://Visionchaudiere.ca/the-district/>.

57. Earl, Jeff. Thompson Perkins and Bronson Pulp Mills Site History and Evolution. Rep. Ot tawa: Fern Mackenzie Consulting Architectural Historian, 2006.3

58. Earl Jeff Thompson Perkins and Bronson Pulp Mills Site History and Evolution. Rep. Ot tawa: Fern Mackenzie Consulting Architectural Historian, 2006.3

59. Sattelberger, Peter, M.A., and Jeff Earl, M.Soc.SC. Richmond Landing/Bronson Mill Ruins Public Access: Heritage Guidance Document. Rep. Maberly: Past Recovery ArchaeologicalServices, 2015. 79

60. Earl, Jeff. Thompson Perkins and Bronson Pulp Mills Site Historyand Evolution. Rep. Ottawa: Fern Mackenzie Consulting Architectural Historian, 2006.3

61. Earl, Jeff. Thompson Perkins and Bronson Pulp Mills Site History and Evolution. Rep. Ot tawa: Fern Mackenzie Consulting Architectural Historian, 2006.5

62. "Erskine Henry Bronson." The Canadian Encyclopedia. N.p., n.d. Web. 03 Oct. 2015. <http://www.thecanadianencyclopedia.ca/en/article/erskine-henry-bronson/s.

63. Bond, Courtney C. J, and Robert U. Mahafffy. "Where Rivers Meet: An Illustrated History of Ottawa." Woodland Hills, CA: Windsor Publications, 1984. 56.

64. Bond, Courtney C. J., and Robert U. Mahaffy. "Where Rivers Meet: An Illustrated History of Ottawa." Woodland Hills, CA: Windsor Publications, 1984. 58

65. "Biography - BRONSON, HENRY FRANKLIN - Volume XI (1881-1890) - Dictionary of Canadian Biography." N.p., n.d. Web. 03 Oct. 2015. <http://www.biographica/en/bio/ bronson_henry_franklin_11E.htm/

66. Erskine Henry Bronson." The Canadian Encyclopedia. N.p., n.d. Web. 03 Oct. 2015 $<$ <ttp://www.thecanadianencyclopedia.ca/en/article/erskine-henry-bronson/>.

67. "Erskine Henry Bronson." The Canadian Encyclopedia. N.p., n.d. Web. 03 Oct. 2015. $<$ <ttp://www.thecanadianencyclopedia.ca/en/article/erskine-henry-bronson/s. 
68. "The District - Vision Chaudiere." Vision Chaudiere. Web. 03 Oct. 2015. <http://Visionchaudiere.ca/the-district/>.

69. Wordlmage. Richmond Landing and Bronson Pulp Mill Ruins Interpretive Content Re search. Rep. Ottawa: Department of Canadian Heritage, 2015. 84

70. Grinder Room Architectural Approach. Rep. Ottawa:Commonwealth Historic Resource Management Limited, 2005.3

71. Grinder Room Architectural Approach. Rep. Ottawa:Commonwealth Historic Resource Management Limited, 2005.3

72. Sattelberger, Peter, M.A., and JeffEarl, M.Soc.Sc. Richmond Landing/Bronson Mill Ruins Public Access: Heritage Guidance Document. Rep. Maberly: Past Recovery Archaeological Services, 2015. 61

73. Grinder Room Architectural Approach. Rep. Ottawa:Commonwealth Historic Resource Management Limited, 2005.3

74. The Canadian Pulp \& Paper Association, Ed. A Handbook of the Canadian Pulp and Paper Industry. Rep. Montreal: Canadian Pulp and Paper Association, 1920.3

75 The Canadian Pulp \& Paper Association, Ed. A Handbook of the Canadian Pulp and Paper Industry. Rep. Montreal: Canadian Pulp and Paper Association, 1920.86

76. The Canadian Pulp \& Paper Association, Ed. A Handbook of the Canadian Pulp and Paper Industry. Rep. Montreal: Canadian Pulp and Paper Association, 1920.86

77. Stephenson, J. Newell. The Manufacture of Pulp and Paper; a Textbook of Modern Pulp and Paper Mill Practice. New York: McGraw-Hill Book, 1927. (Section 2, 13)

78. The Canadian Pulp \& Paper Association, Ed. A Handbook of the Canadian Pulp and Paper Industry. Rep. Montreal: Canadian Pulp and Paper Association, 1920.86

79. The Canadian Pulp \& Paper Association, Ed. A Handbook of the Canadian Pulp and Paper Industry. Rep. Montreal: Canadian Pulp and Paper Association, 1920. 86

80. The Canadian Pulp \& Paper Association, Ed. A Handbook of the Canadian Pulp and Paper Industry. Rep. Montreal: Canadian Pulp and Paper Association, 1920.87

81. HP Engineering. Bronson Pulp Mill Ruins National Capital Commission Draft Structura/ Assessment Report. Rep. Ottawa: National Capital Commission, 2015. 7

82. HP Engineering. Bronson Pulp Mill Ruins National Capital Commission Draft Structural Assessment Report. Rep. Ottawa: National Capital Commission, 2015. 18

83. HP Engineering. Bronson Pulp Mill Ruins National Capital Commission Draft Structural Assessment Report. Rep. Ottawa: National Capital Commission, 2015.8

84. HP Engineering. Bronson Pulp Mill Ruins National Capital Commission Draft Structural Assessment Report Rep. Ottawa: National Capital Commission, 201518

85. HP Engineering. Bronson Pulp Mill Ruins National Capital Commission Draft Structural Assessment Report. Rep. Ottawa: National Capital Commission, 2015.8

86. HP Engineering. Bronson Pulp Mill Ruins National Capital Commission Draft Structural Assessment Report Rep. Ottawa: National Capital Commission, 2015.
87. HP Engineering. Bronson Pulp Mill Ruins National Capital Commission Draft Structural Assessment Report. Rep. Ottawa: National Capital Commission, 2015. 10

88. HP Engineering. Bronson Pulp Mill Ruins National Capital Commission Draft Structural Assessment Report. Rep. Ottawa: National Capital Commission, 2015. 19

89. HP Engineering. Bronson Pulp Mill Ruins National Capital Commission Draft Structura Assessment Report. Rep. Ottawa: National Capital Commission, 2015. 10

90. HP Engineering. Bronson Pulp Mill Ruins National Capital Commission Draft Structural Assessment Report. Rep. Ottawa: National Capital Commission, 2015. 20

91. HP Engineering. Bronson Pulp Mill Ruins National Capital Commission Draft Structural Assessment Report. Rep. Ottawa: National Capital Commission, 2015. 15

92. HP Engineering. Bronson Pulp Mill Ruins National Capital Commission Draft Structural Assessment Report. Rep. Ottawa: National Capital Commission, 2015.22

93. HP Engineering. Bronson Pulp Mill Ruins National Capital Commission Draft Structural Assessment Report. Rep. Ottawa: National Capital Commission, 2015. 15

94. HP Engineering Bronson Pulp Mill Ruins National Capital Commission Draft Structural Assessment Report. Rep. Ottawa: National Capital Commission, 2015.22

95. HP Engineering. Bronson Pulp Mill Ruins National Capital Commission Draft Structura Assessment Report. Rep. Ottawa: National Capital Commission, 2015. 13

96. HP Engineering. Bronson Pulp Mill Ruins National Capital Commission Draft Structural Assessment Report. Rep. Ottawa: National Capital Commission, 2015.21

97. HP Engineering. Bronson Pulp Mill Ruins National Capital Commission Draft Structural Assessment Report. Rep. Ottawa: National Capital Commission, 2015.14

98. HP Engineering. Bronson Pulp Mill Ruins National Capital Commission Draft Structural Assessment Report. Rep. Ottawa: National Capital Commission, 2015. 21

99. HP Engineering. Bronson Pulp Mill Ruins National Capital Commission Draft Structural Assessment Report. Rep. Ottawa: National Capital Commission, 2015.9

100. HP Engineering. Bronson Pulp Mill Ruins National Capital Commission Draft Structural Assessment Report. Rep. Ottawa: National Capital Commission, 2015.9

101. HP Engineering. Bronson Pulp Mill Ruins National Capital Commission Draft Structural Assessment Report. Rep. Ottawa: National Capital Commission, 2015.19

102. HP Engineering. Bronson Pulp Mill Ruins National Capital Commission Draft Structural Assessment Report Rep. Ottawa: National Capital Commission, 2015.11

103. HP Engineering. Bronson Pulp Mill Ruins National Capital Commission Draft Structural Assessment Report. Rep. Ottawa: National Capital Commission, 2015. 19 


\title{
Part III:
}

\author{
Dissemination
}




\section{Interpretation Centre Design 3.1:}

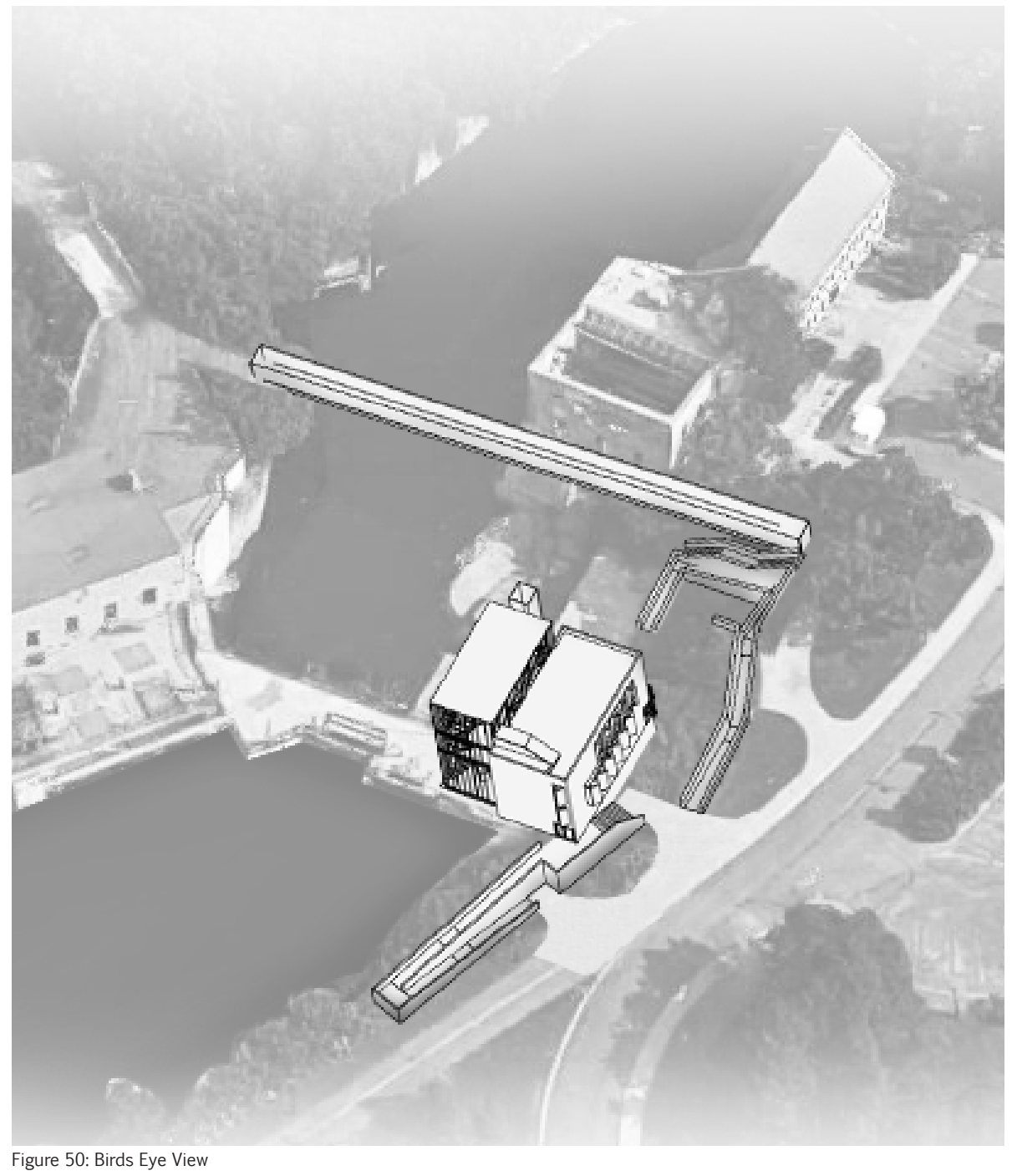

The ruins of the Bronson Pulp Mill are located within a historic area that is often neglected in the accounts of Ottawa's history. This apparent lack of information is owing predominantly to the inaccessibility of the site, both intellectually and physically. The design of an interpretation centre created in situ of the ruins will provide the much needed infrastructure required for the inhabitation of the site, while the program allows for the knowledge of the site to be shared. Through this Interpretation Centre the dissemination of the traces of the past will occur.

This location is a key node, acting as an entrance to the Chaudière Falls and surrounding islands. The Interpretation Centre further utilizes this advantageous location by creating a new, interactive, destination for visitors of the Chaudière Falls. There are 


\section{5}

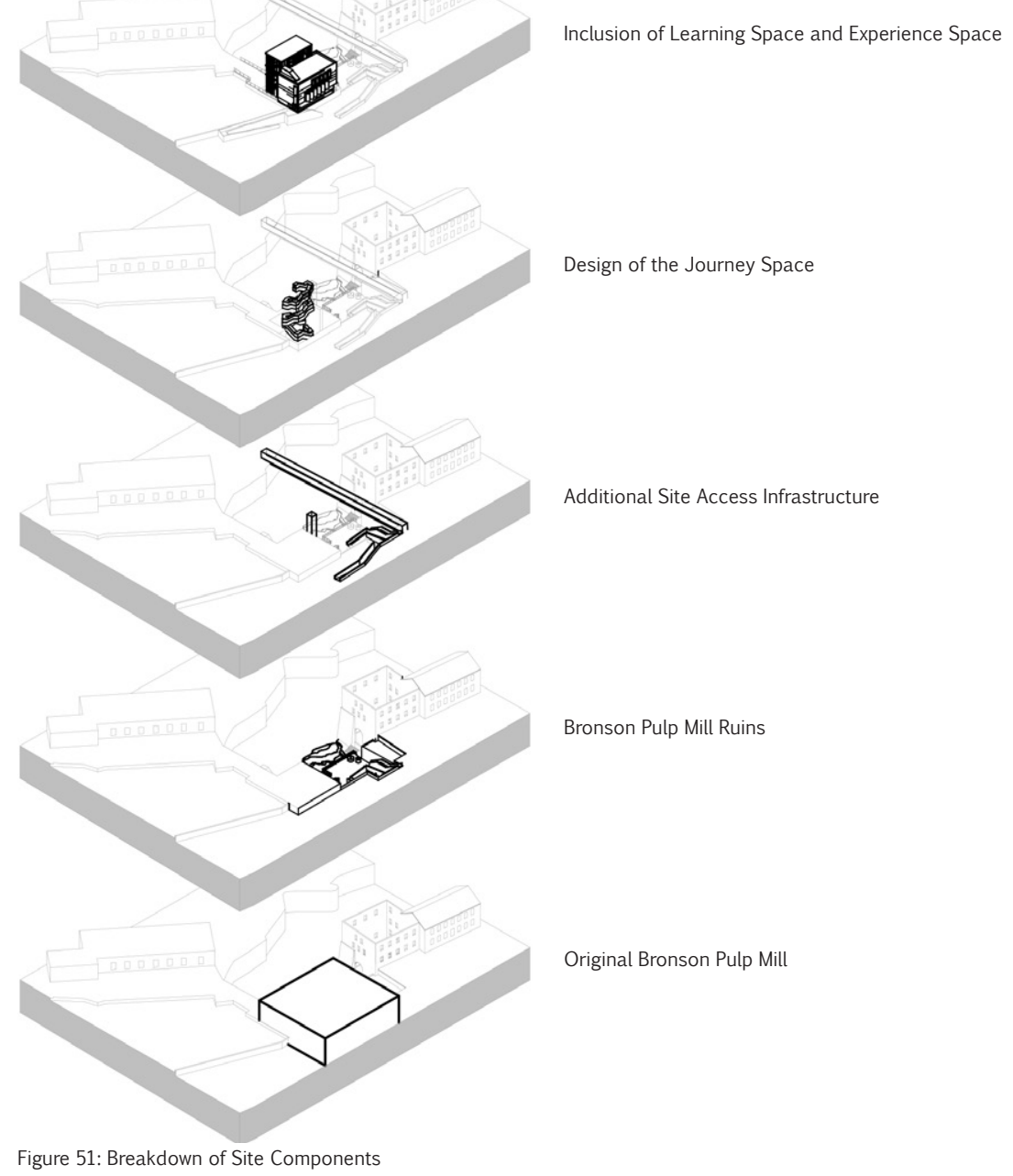

two phases to this proposal: the External Design and the Internal Design. The External Design will look at the accessibility and refurbishment of the present ruins, as well as the site's connection to the islands beyond as part of a study of the Greater Context. The Internal Design will include the design of the Interpretation Centre which will house the different levels of interpretation (Greater Context, Surrounding Context, Immediate Context, Tangible Context, and Intangible Context) within the experience space. While there is a formal space for learning, the centre of the proposal is that learning takes place in all aspects of the site. 


\section{Understanding}

a. Heritage Value \& Character Defining Elements

Reference Figure 30: Classification of Character Defining Elements.

b. Document Conditions and Changes

Analysis of current conditions. Reference pages 38-43.

\section{Planning}

a. Maintain or Select Appropriate and Sustainable Use

An Interpretation Centre creates new life for the area, while keeping the history of the site in mind.

b. Identify Project Requirements

Access to remaining infrastructure, and infromation that relates to the site.

c. Determine the Primary Treatment

Rehabilitation through the design of an Interpretation Centre and how this is incorporated with the existing infrastructure.

d. Review the Standards

e. Follow the Guidelines

\section{Intervening}

a. Undertake the Project Work

Design of the two phases: External Design, and Internal Design.

b. Carry out Regular Maintenance

The interpretation located within the centre will be frequently reanalyzed for revelance and any additional interpretation that is available. On site staff allow constant upkeep of remaining infrastructure pieces.

Figure 52: Standards \& Guidelines
This thesis explores the use of interpretation as a means of conserving heritage sites. The following chart is a brief breakdown of how these main points of heritage conservation are covered and where they are located within the document. This is done through the use of The Standards and Guidelines for the Conservation of Historic Places in Canada, which outlines the primary approaches of understanding,

\section{planning and intervening.}




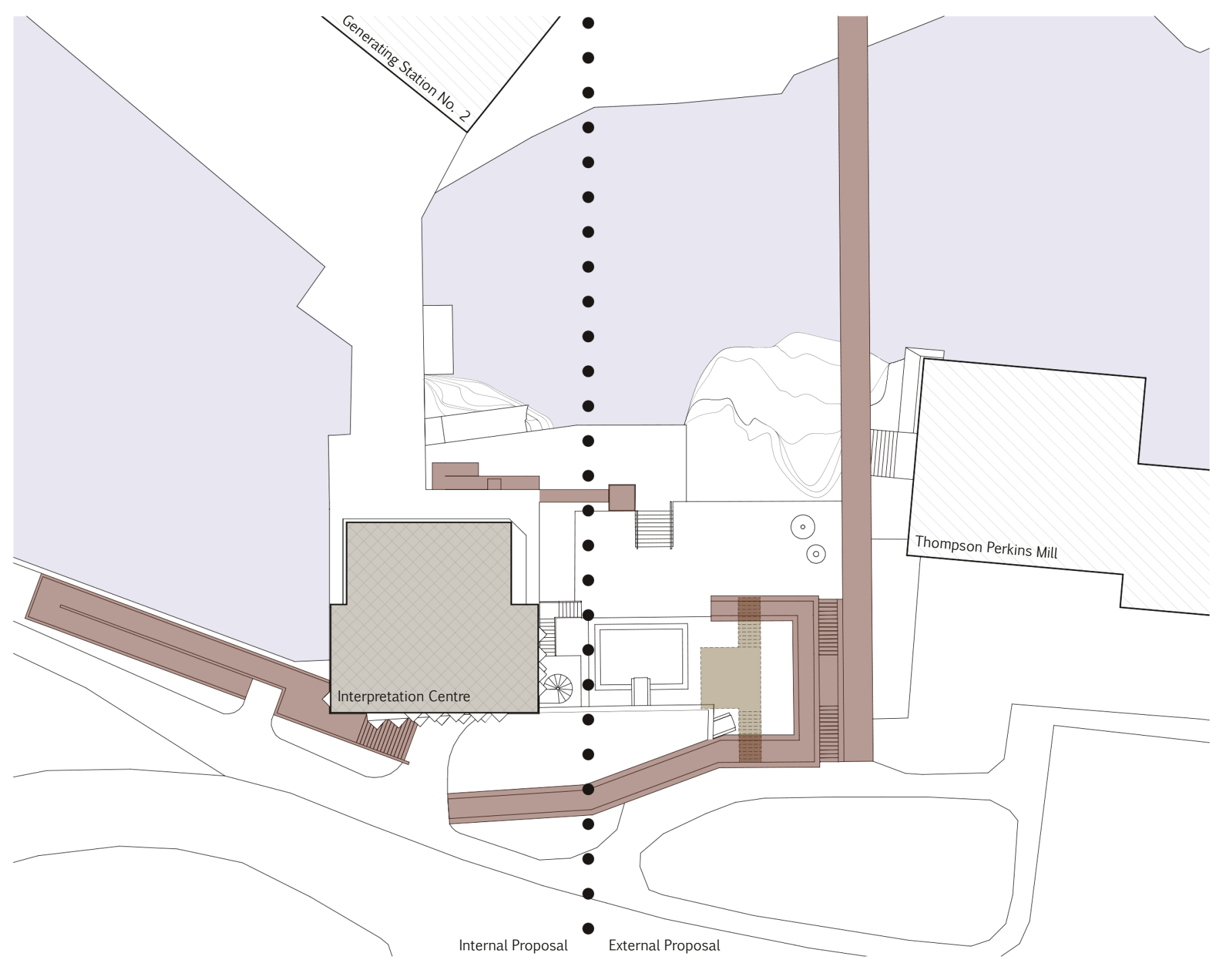

Figure 53: Site Plan
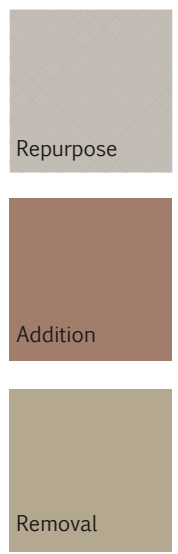
The design of the Interpretation Centre will abide by the guidelines set forth in Part I by the ICOMOS Charter for the Interpretation and Presentation of Cultural Heritage Sites. The following explains how these principles are further implemented by the design.

Access and Understanding ${ }^{104}$

The central idea of this principle is that interpretation "should facilitate physical and intellectual access by the public". ${ }^{105}$ In the 1970's the NCC added new infrastructure to the site in an attempt to make the ruins accessible to the public by constructing new platforms, staircases and landings. However, the means of circulation through the site were not revised as the building code evolved, and the site is now closed, as it does not meet current accessibility standards. The circulation through the site is the first issue to be addressed, based on the recommendations suggested by HP Engineering. These changes will enable proper access to the site. The accessibility requirements will be met in the form of a ramp, beginning at the point where the timber used to enter the mill. The ramp extends down into the site, following the line of the old timber chute. The second point of access is an exterior elevator that allows access to all viewing platforms. Lastly, all railings will be updated in accordance with current building code. To improve circulation around the site, a pedestrian bridge will be built in the location where the old timber mill (now demolished) once extended across to the other side of the canal. This bridge connects the shores of Ottawa directly to the islands. 
The issue of intellectual access to the history of the site is addressed by the Interpretation Centre itself, which includes all the levels of interpretation. The interpretation centre provides a much needed central archive for the accumulation and dissemination of historic material regarding the Chaudière Falls, as this information is currently scattered throughout many archives and libraries within the city. This intellectual accessibility makes the history of the area more readily available to the general population.

\section{Information Sources ${ }^{106}$}

Information sources are "based on evidence gathered through accepted scientific and scholarly methods as well as from living cultural traditions." ${ }^{\prime 107}$ Each type of reference source is represented in the interpretation that takes place within the Centre. The
Scholarly method takes information from published books on the historical aspects of the Chaudière Falls; it looks at events, timeframes, and the people who were involved in its development. The scientific methods used, look at reports that have been compiled including archeology, structural assessments, as well as examining the historical cartography of the site. The final method drawing from living culture is more intangible. It looks at the traditional aspects of the site, including how the Algonquin used the site as a ceremonial ground and their relationship with the water. Together, these different means of collecting information create a depth of interpretation that is richly layered and comprehensive.

\section{Attention to Setting and Context ${ }^{108}$ \\ The interpretation "should relate to their wider social,}


cultural, historical, and natural context and settings $^{\prime 109}$ The Bronson Pulp Mill Interpretation Centre examines all aspects that have influenced the site. This includes looking at the natural phenomenon that formed the site, ecosystems that are moulded around it, the prehistory of the site, the indigenous or more specifically Algonquin settlement in the area, the explorers, fur traders, and industrial settlement with its exploitation of the river. Together, all of these aspects have created a dynamic and culturally significant site.

\section{Preservation of Authenticity ${ }^{110}$}

The Authenticity of the site looks to incorporate "the spirit of the Nara Document". ${ }^{111}$ Within this document it states "All cultures and societies are rooted in the particular forms and means of tangible and intangible expression which constitute their heritage, and these should be respected". ${ }^{112}$ The Chaudière Falls and islands hold both the tangible and intangible heritage that is referenced in this statement; both of these traditions will be represented within the interpretation centre. The tangible will be represented through found artifacts, and the intangible through the art of storytelling, and industrial processes that have occurred at the site.

The Interpretation Centre itself is located within the ruins of the Bronson Pulp Mill, and must respect the remaining fragments that still exist on site. The construction of the learning space will draw from the past architecture of the site through the use of heavy materials with little glazing. In the experience space the building opens up to the Chaudière Falls. 
Specific views are framed in relation to the corresponding level of interpretation. The building itself will touch the ruin at key moments, and break through the concrete structure only when important moments are available, similar to the machinery elements that occasionally broke through the concrete wall when the Pulp Mill was functioning. The remaining infrastructure of the mill is predominantly concrete, and all new interventions will incorporate glass, wood and steel to differentiate the new from the old.

\section{Planning for Sustainability ${ }^{113}$}

When planning for sustainability in the Interpretation Centre, the important aspect of the site is to "be sensitive to its natural and cultural environment."114 One aspect of sustainability is to educate the general population about the problems that were encountered throughout the building of the Interpretation Centre and interpretation process. The Interpretation Centre, in its sensitive assessment of its surroundings, provides a template for a new architecture of industrial interpretation. One of the concerns encountered during the design stage, was how to open up the accessibility of the site without compromising the existing ruin. The solution was a sensitive insertion of new infrastructure in a way that complemented the site, and was only added when absolutely necessary. There is a significant height differential from street level to water level, and to allow access to the canal, a ramp was proposed. To maintain the sense of space and keep the ruins unencumbered with new infrastructure the proposed ramp is partially set outside the ruins. 


\section{Concern for Inclusiveness ${ }^{115}$}

The result of inclusiveness is a "meaningful collaboration between heritage professionals, host and associated communities, and other stakeholders."

116 The interpretation at the Bronson Pulp Mill Ruins and Chaudière Falls looks to include those who

have had an influence on the area. This includes the Algonquin, the industrialists, and future interpretation.

Importance of Research, Training, and Evaluation ${ }^{117}$ Research, Training, and Evaluation is meant to be a continuing process. The basis of an Interpretation Centre is to teach what is otherwise unknown to the community. This is further emphasised through the classroom, media room, and small theatre all located within the Interpretation Centre. These programmatic elements provide an environment for more formal learning. The Experience Area provides a space for more interactive learning through exhibitions and guest storytellers who share further knowledge through the traditions of the local Algonquin people. There are also services located onsite for ongoing research within the staff facilities. This will allow the sharing of resources on a larger scale. 


\section{External Design 3.2:}

The primary concern of the existing ruins is to allow universal access. This access must encompass and allow for physical, visual, and auditory impairments. To allow access to the site all current features will need to be brought up to the current building code. In the case of the Bronson Pulp Mill ruins the railings will need to be replaced, and all areas where access is allowed must be properly enclosed. The main site access is the previously mentioned ramp system, bridge and external elevator.

The second concern of the Bronson Pulp Mill Ruins is ensuring that all elements prove to be safe for human interaction. This includes the removal or improvement of all hazardous elements. Based off the previously mentioned report completed by HP Engineering, this would include the removal or replacement of staircases, improvement of the material qualities of the remaining foundation walls, and improvement and repair of the remaining mechanical equipment. These repairs will allow safe interaction between pedestrians and the ruins to occur. 


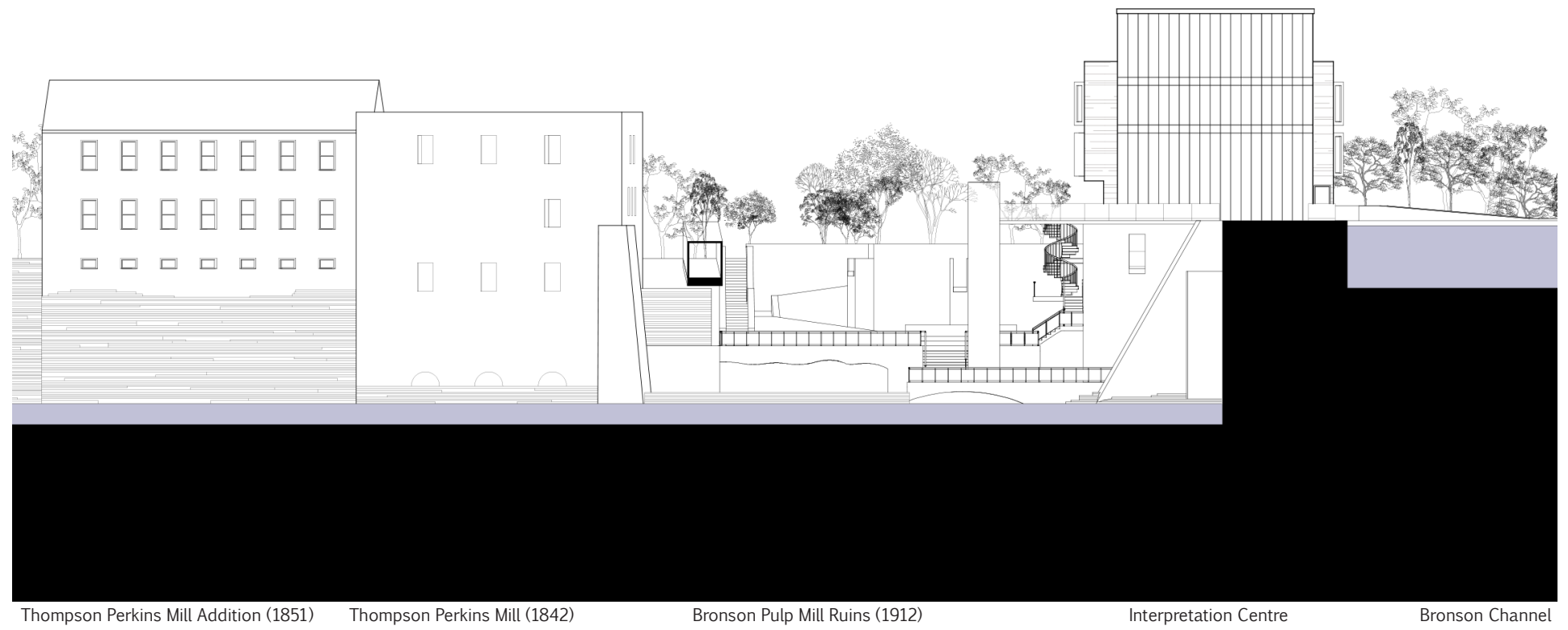




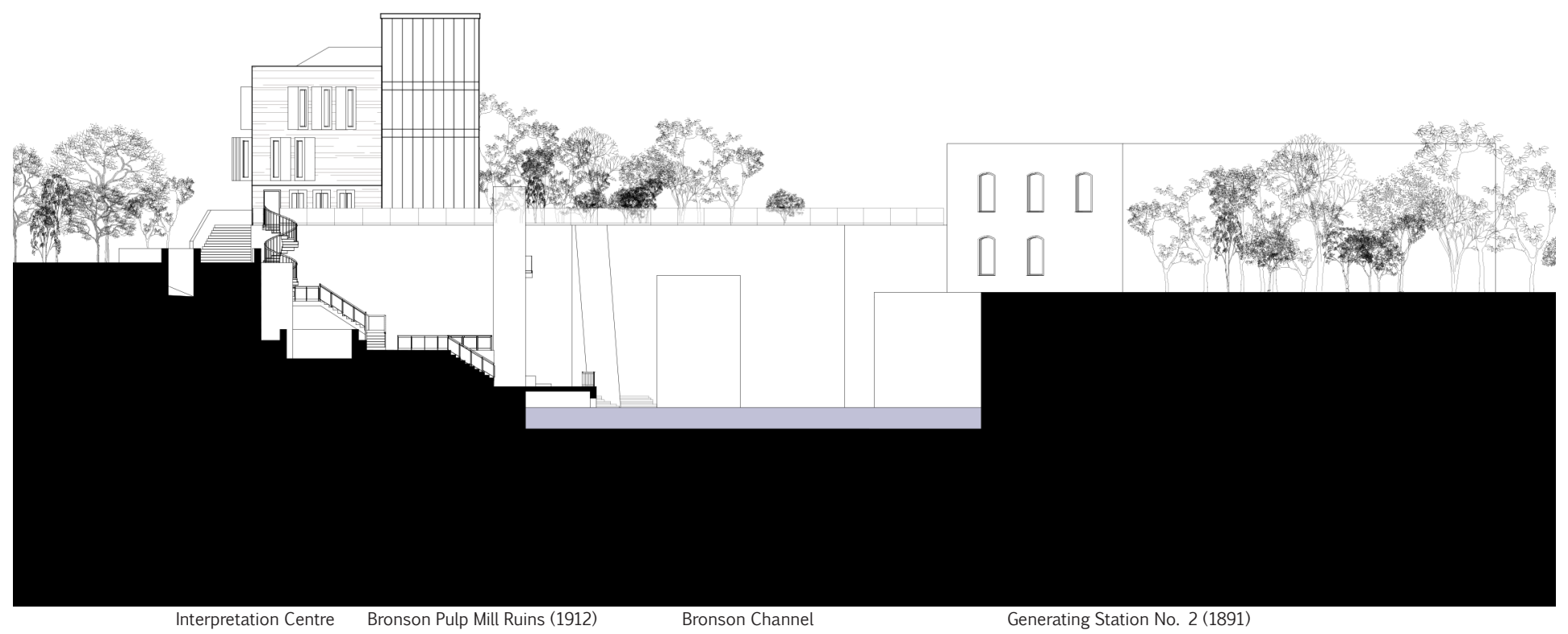




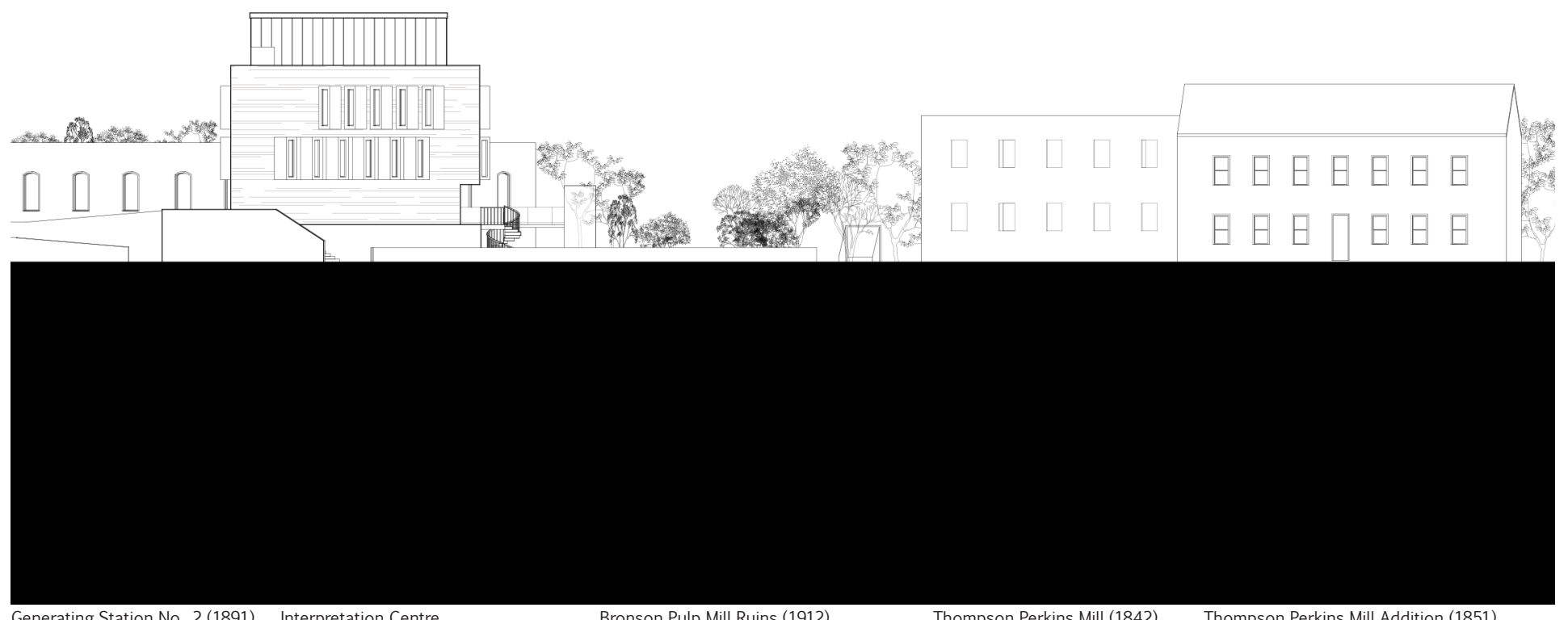




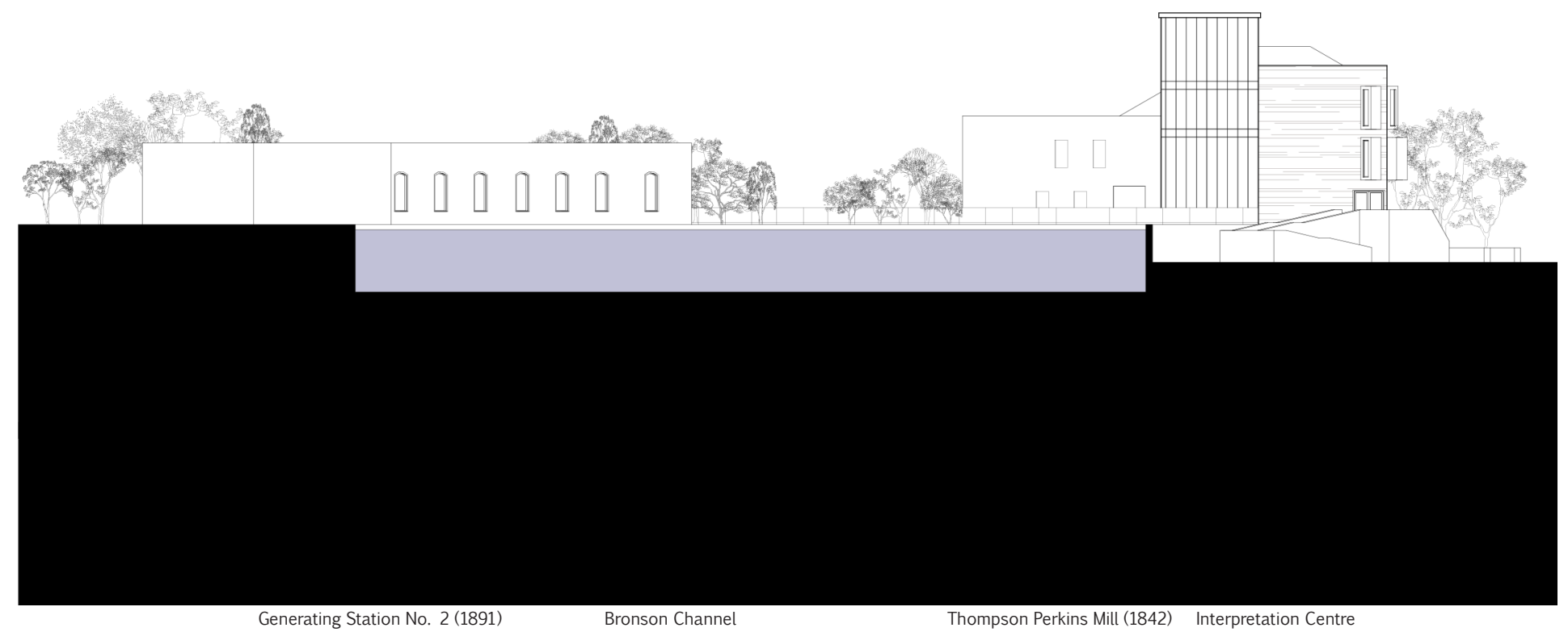




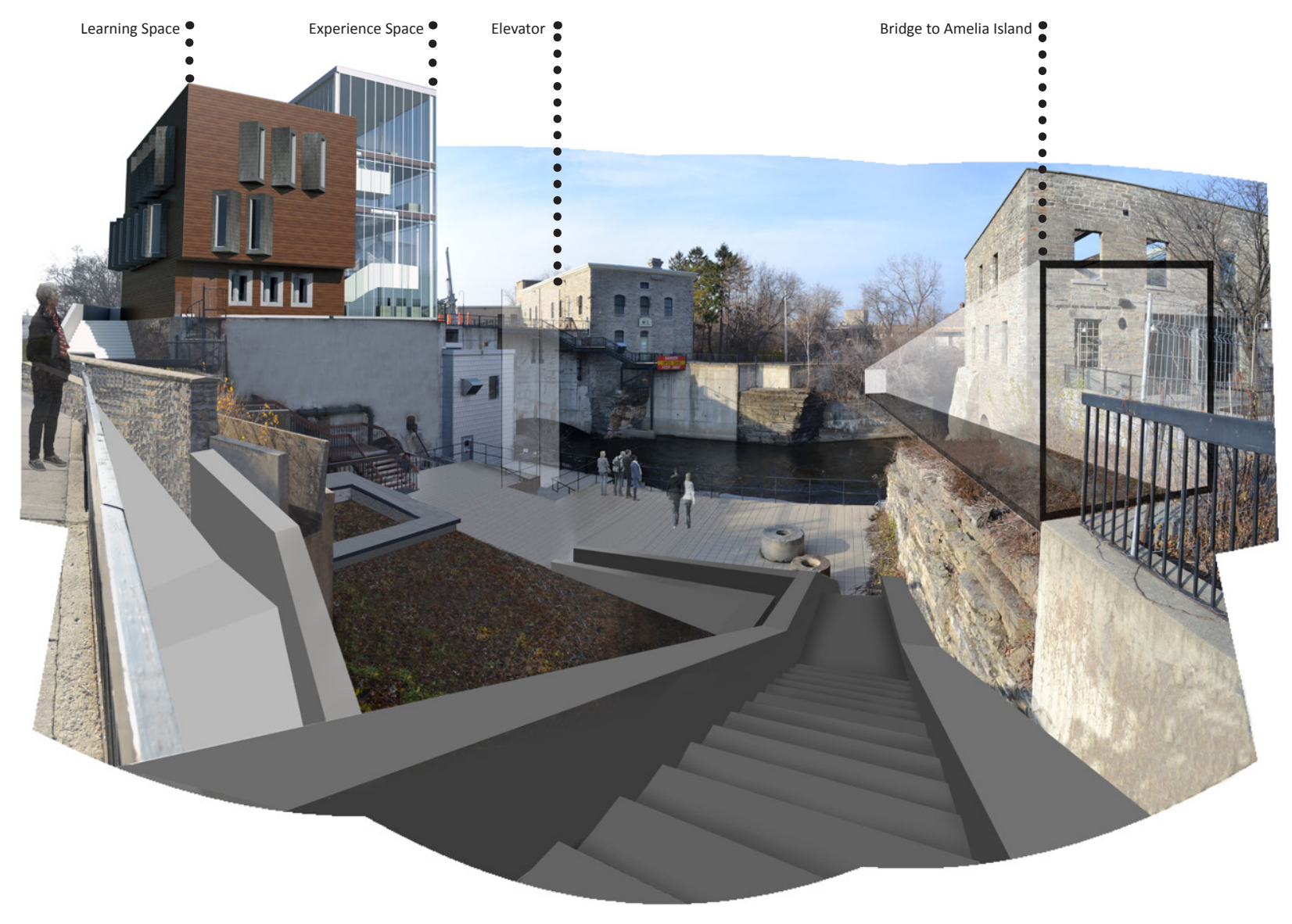


Figure 59: View from Driveway

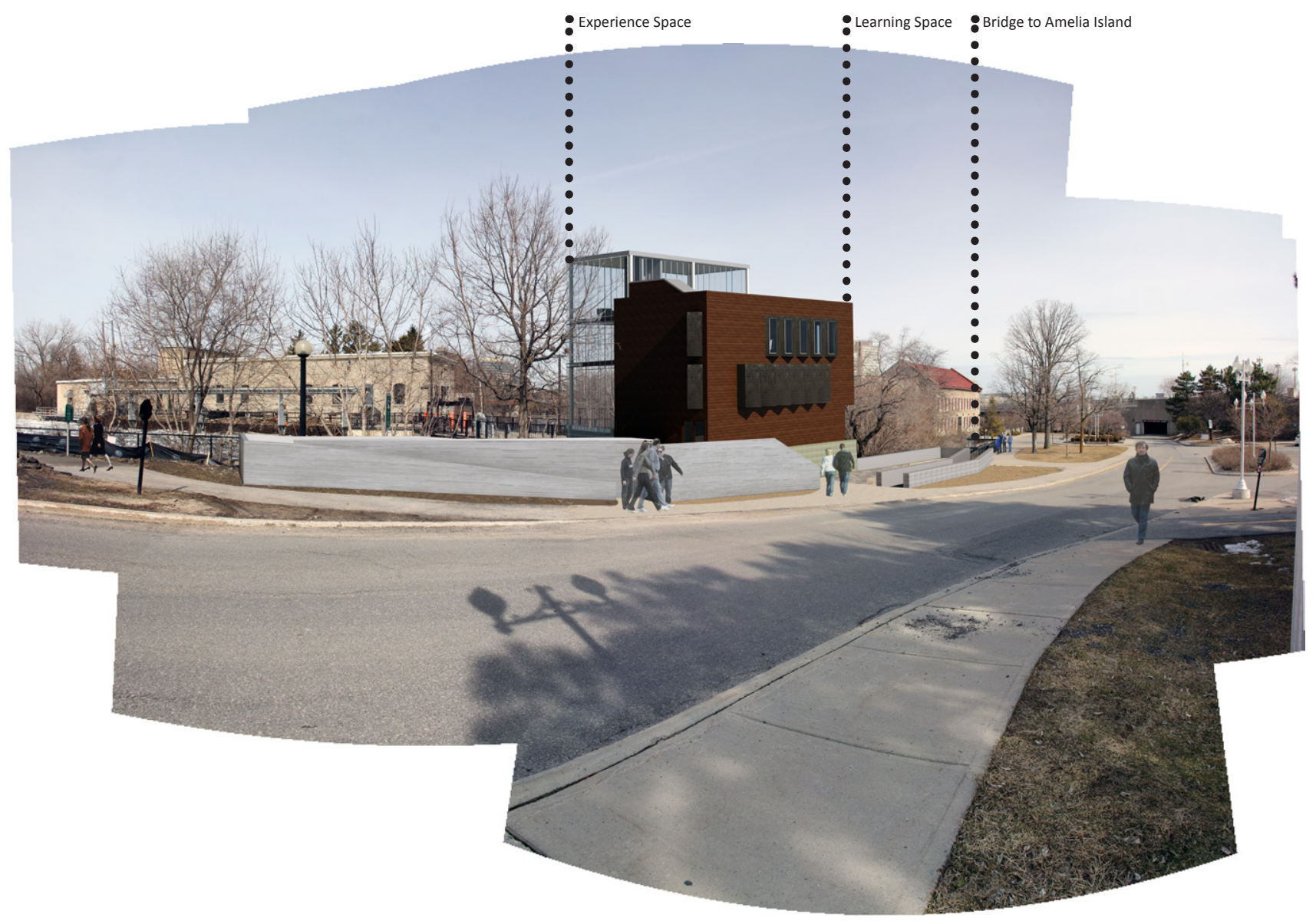




\section{Internal Design 3.3:}

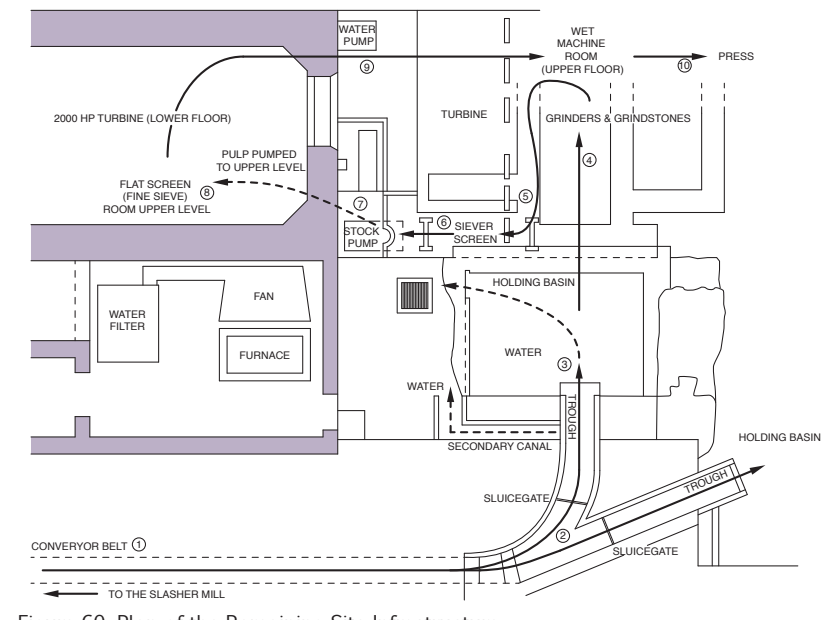

Figure 60: Plan of the Remaining Site Infrastructure

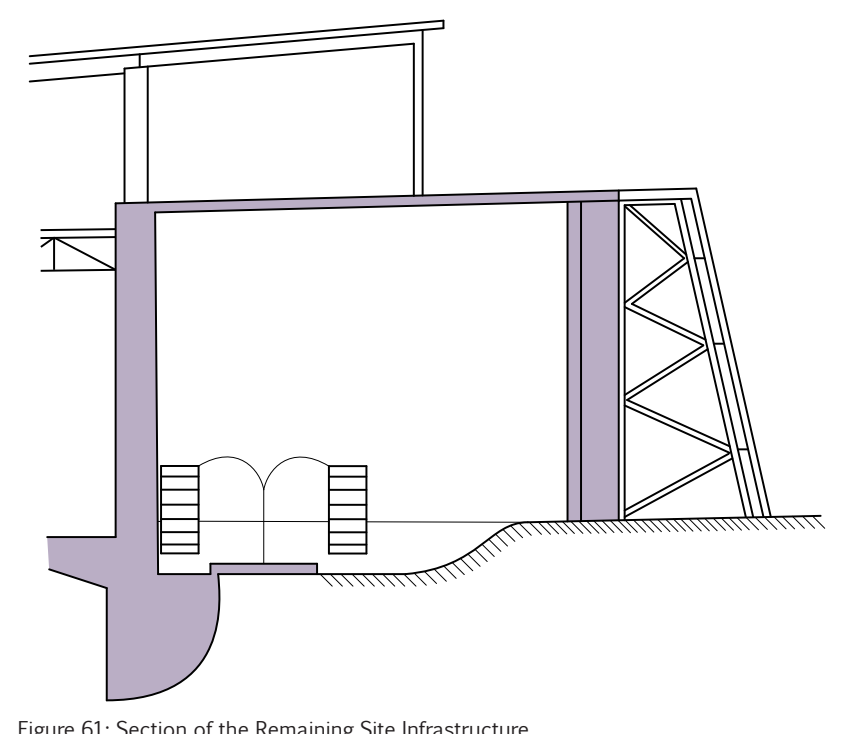

Figure 61: Section of the Remaining Site Infrastructure
The Interpretation Centre is located in the western portion of the Bronson Pulp Mill Ruins and is situated on the old grinder storage room. There are only a few original drawings remaining of what the pulp mill looked like. Two that exist are a plan of how the pulp mill functioned and a section cutting through the room where the turbine was housed within the Grinder storage room. These two drawings were used to interpret what these remaining spaces from the Bronson Pulp Mill look like. It was determined that that the northern room has no floors and is empty. It is in this portion of the ruins that the Interpretation Centre will house exhibition spaces.

Conceptually the design of the Interpretation Centre is made up of four components. The Existing Ruins the Learning Space, the Experience Space, and the 

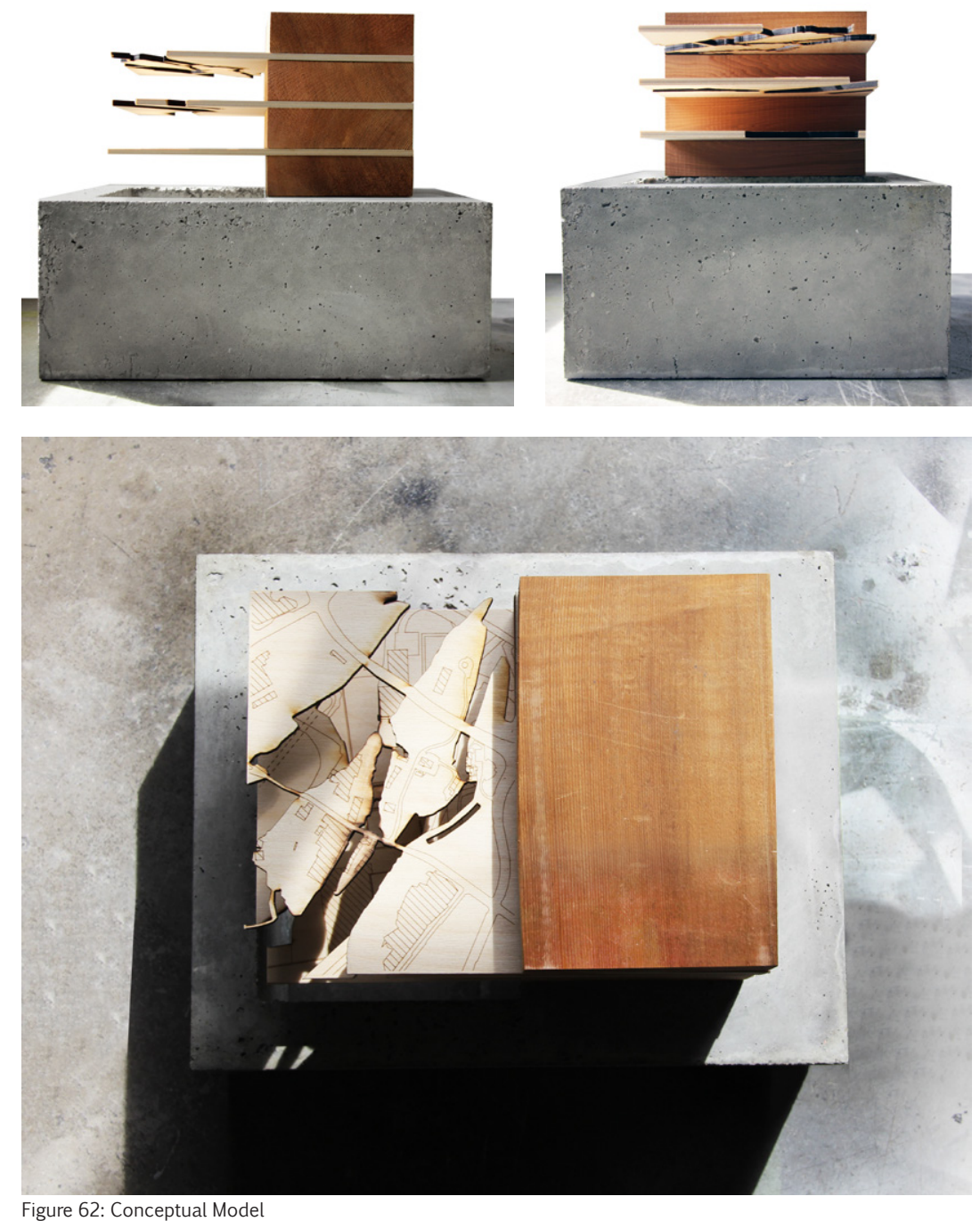

Journey Space, all of which are meant to have different qualities. A conceptual model was created and used to explore these components and their relationship to each other. This was done through the use of different materials (concrete and wood), and mediums (cast-in-place, etched wood, solid wood). (Figure 62)

The Learning Space is mostly enclosed, similar to the original pulp mill that once stood in the same location. It is in this area that a more internalized experience occurs. The only views to outside are rigorously framed, enclosing culturally significant portions of the surrounding landscapes, including Gatineau (the significance of the French-English relations in the development of the Falls), the Ottawa River (the site of the first industrial landscape in the Ottawa 


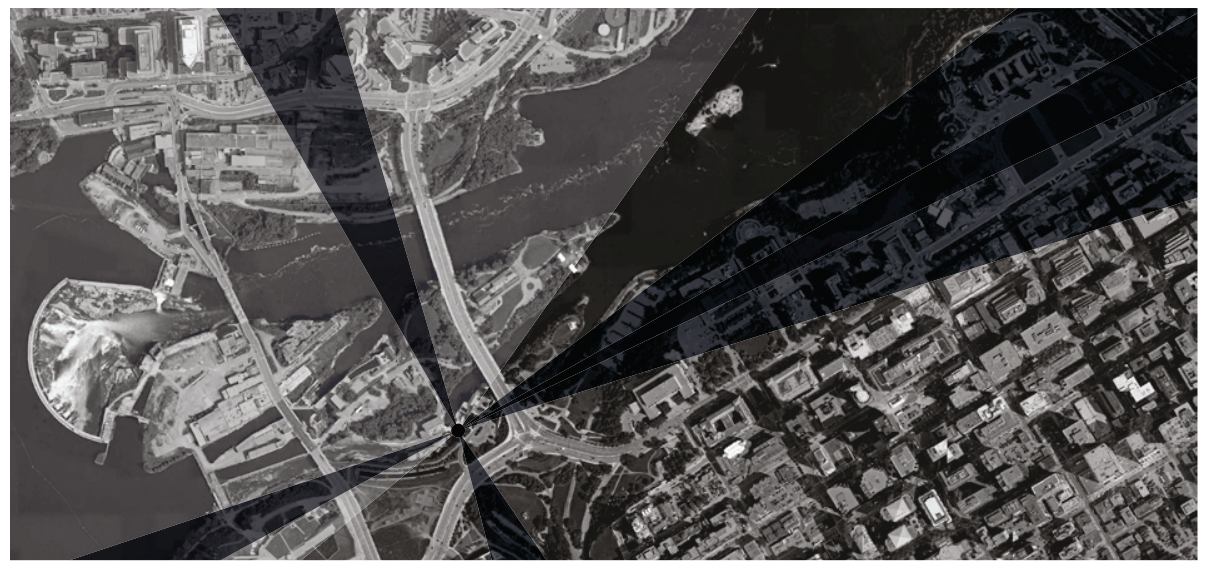

Figure 63 Views provided from the Interpretation Centre
River Valley), Lebreton Flats (a greatly contested site, once a prominent industrial neighbourhood), and the Parliamentary Precinct (the seat of the Capital.) (Figure 63) Within this space one will find the information kiosk, café, classroom, washrooms, media room, a theatre, and staff facilities.

The experience space is the balance to the learning space. As an intentionally open space it encourages the connection with the interpretation being presented. This area is made up of five floors, each with a focus on a different scale. You begin in the intangible level, where you commence by seeing the roots of the project, hear the stories of the Algonquin people who found the site to be sacred, and learn of the natural history of the area. From this level one has the opportunity to go out to the rocks and see 


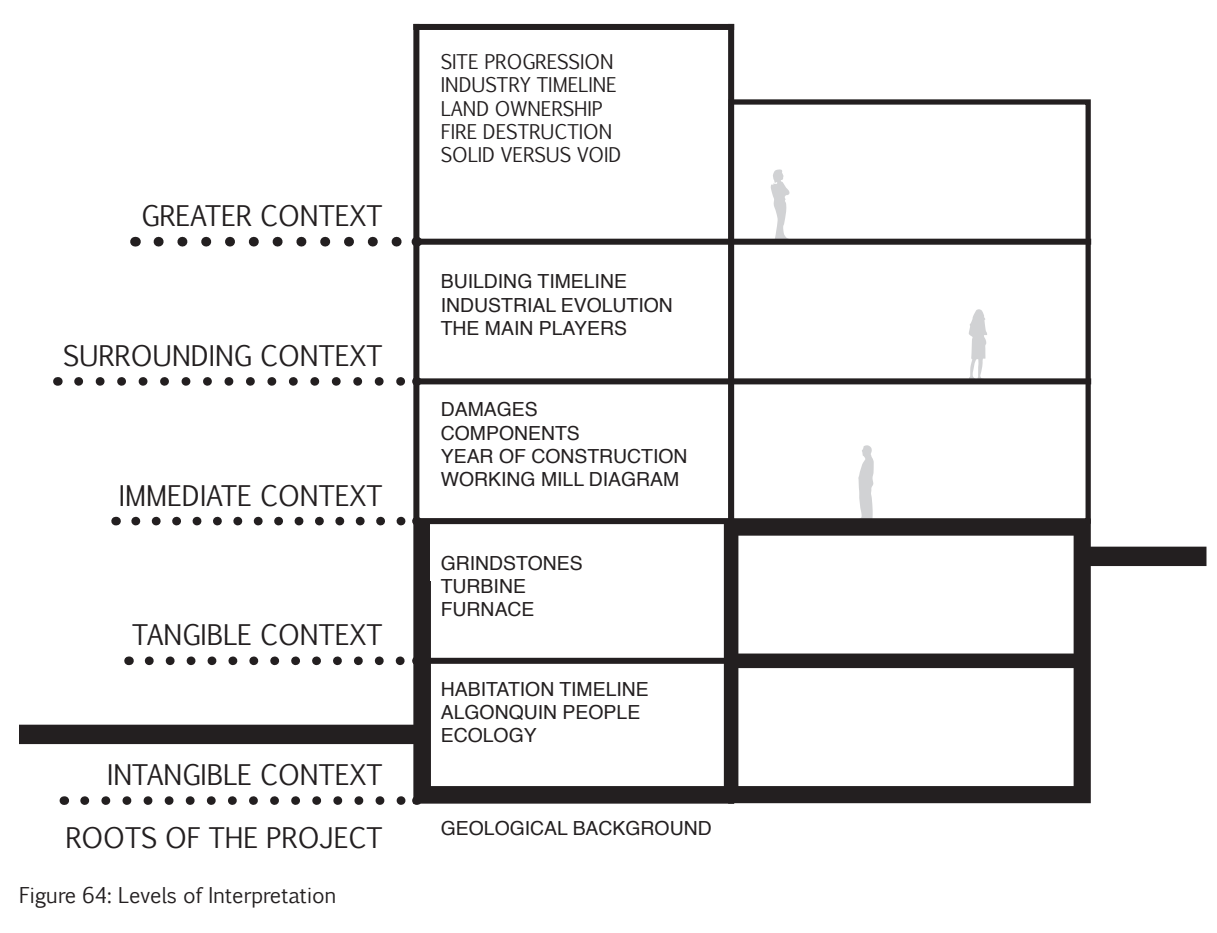

Figure 64: Levels of Interpretation the canal up close from the bottom of the ruins. The Algonquin have a spiritual connection with the water, and in this location the stories of the Algonquin people will be told. Once back inside, you proceed upwards to the tangible level, and learn of the tools and artifacts. On this level you are able to access the part of the pulp mill that housed the furnace and other artifacts, as well as go outside and see portions of the ruins as well as the dam. The next level is the immediate context, comprised of all the information of the pulp mill itself. From this level you have a vantage point of the remaining aspects and can exit take an elevator down, and experience what you just learned in the immediate context. By taking the elevator back up you travel in the direction the pulp took before it was made into paper. It is on this level that maps etched onto the floor begin to tell 


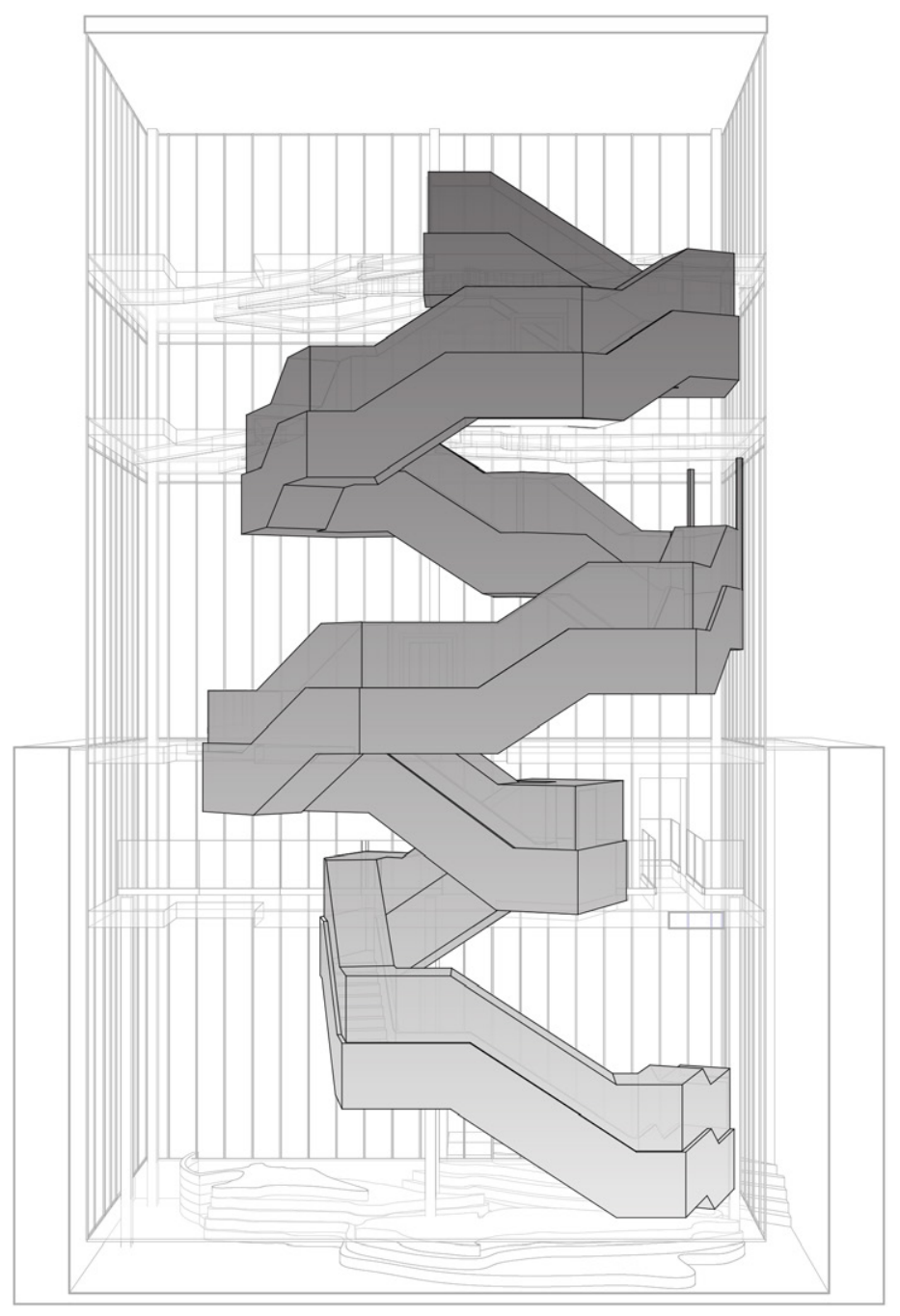

Figure 65: Journey Diagram the story of the surrounding water in relation to that level's interpretation. The etched bodies of water are replaced with glass, which allows for a visual connection to the level below. This use of glass and water also occurs on the two levels above. The experience space continues with the surrounding context and greater context; it is on these levels that one begins to understand the significance of the location, as one is immersed in views the Chaudière Falls and surrounding islands.

This experience is not possible without the journey space. This space frames one's movement through the building, allowing glimpses into the different areas as one travels upwards. The journey begins after using the elevator to go down to the lowest level, before proceeding upwards in a continuous, weaving path. 


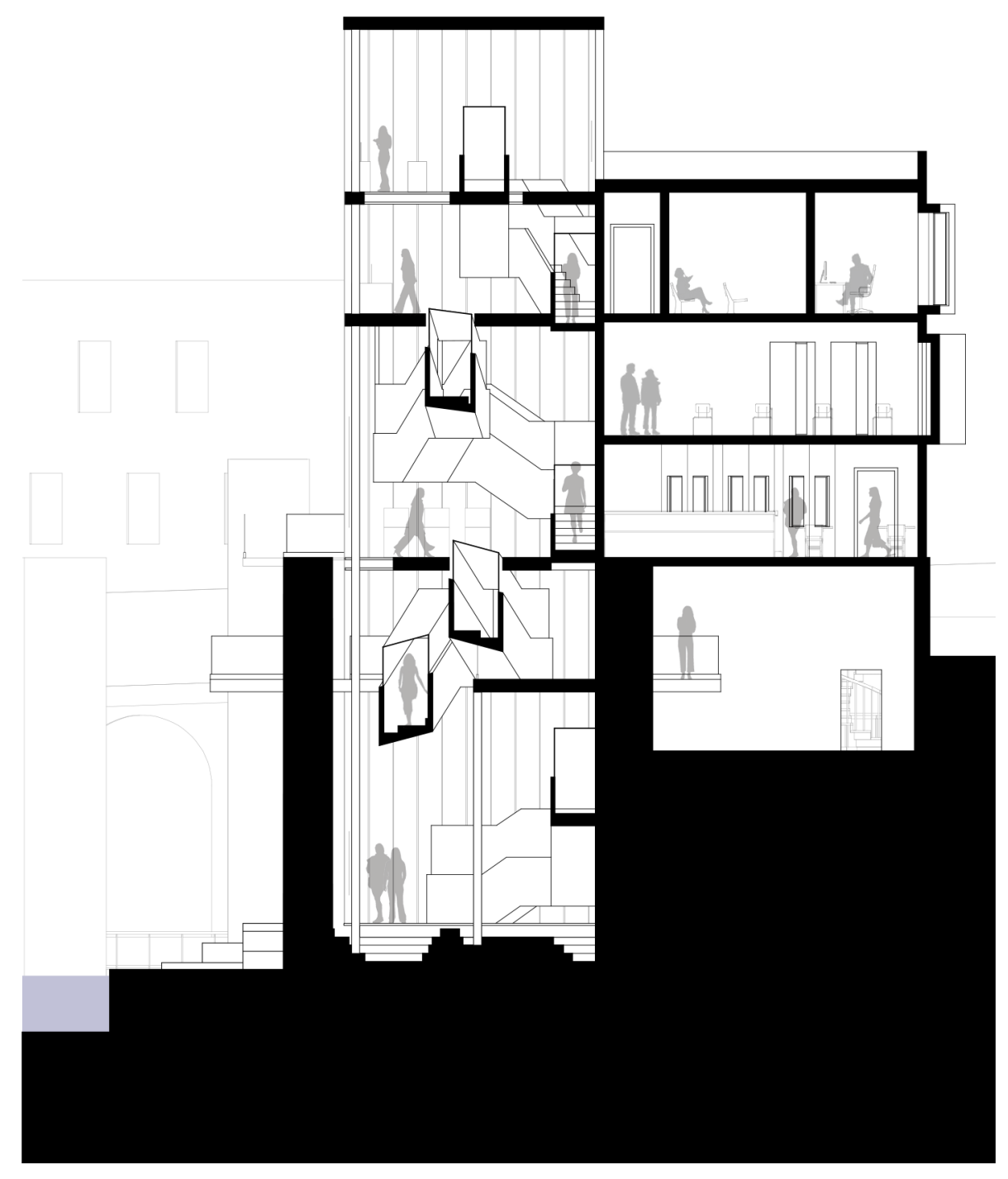

Figure 66: Section 1 


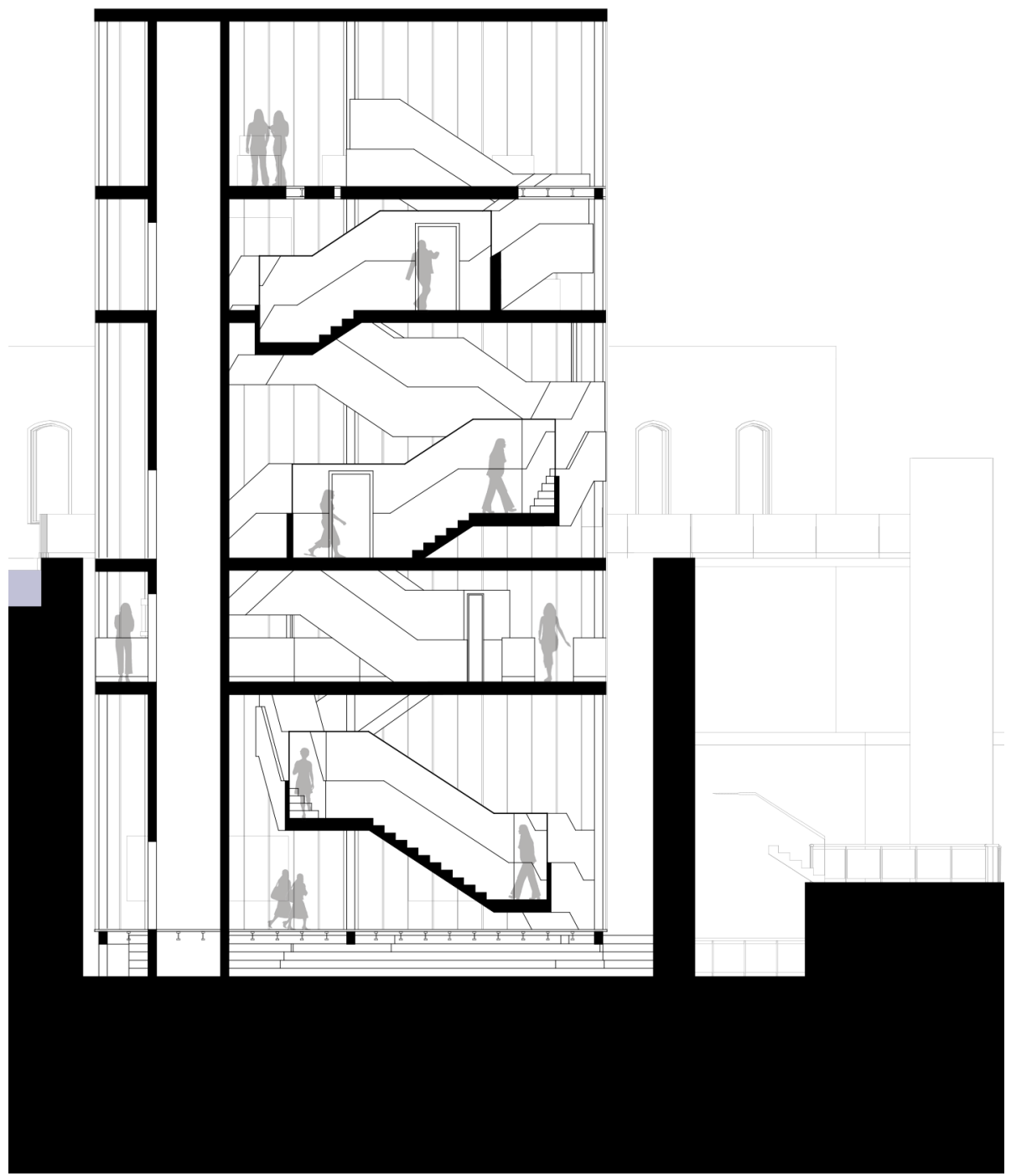

Figure 67: Section 2 


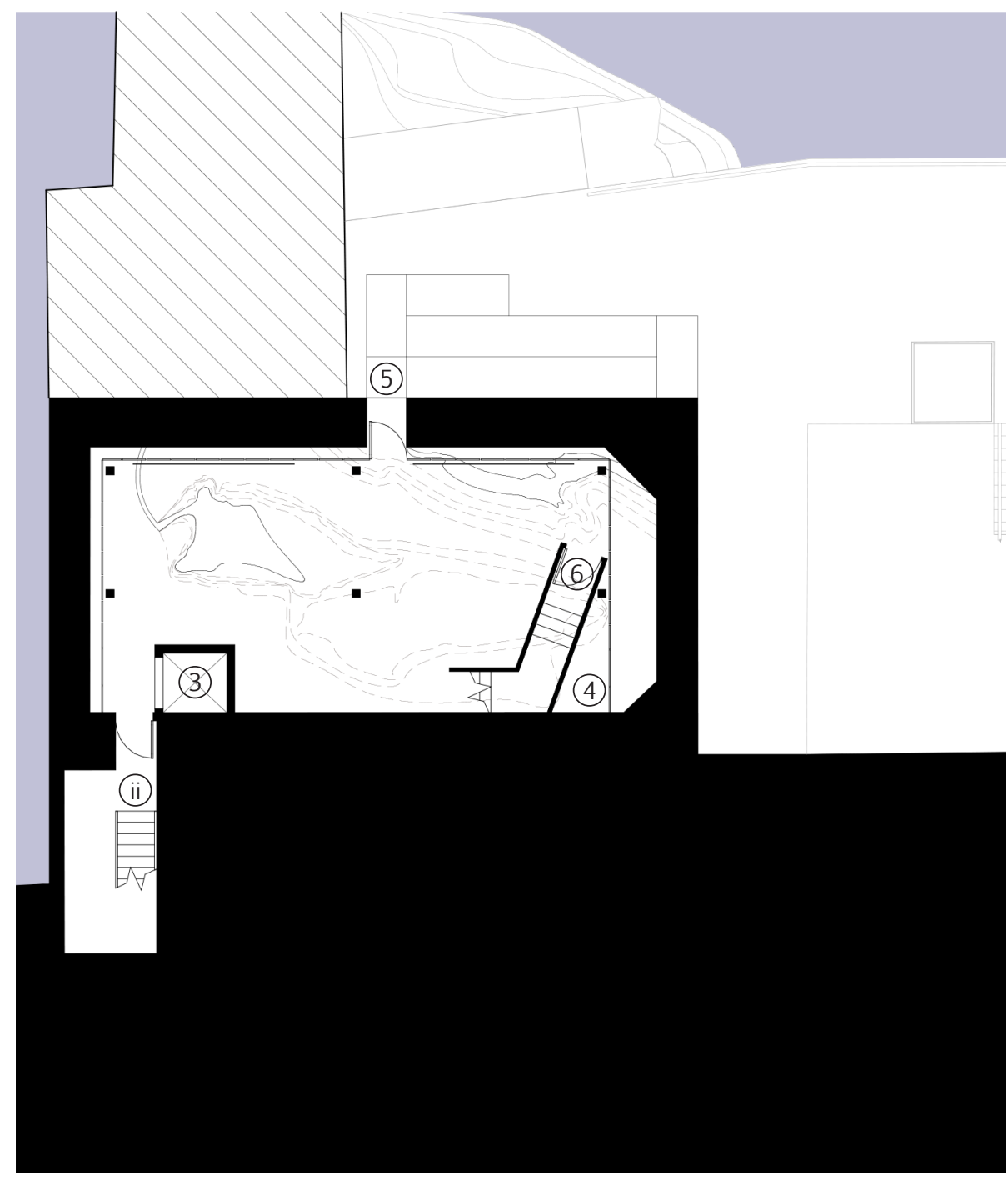

Figure 68: Level-2

Elevator (3)

Intangible Exhibition (4)

Connection to the Earth (5)

Journey Stairs (6)

Stairs (ii) 


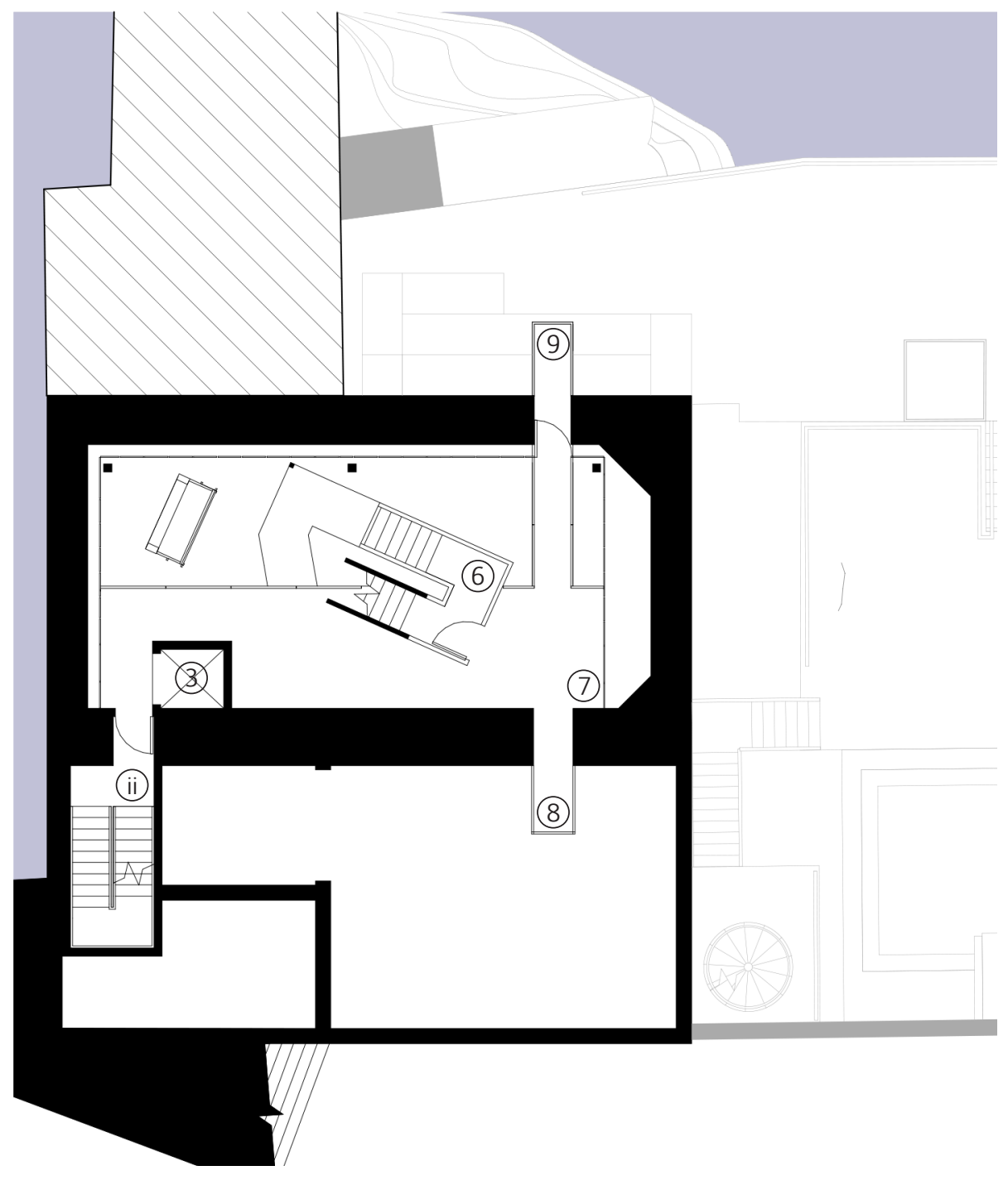

Figure 69: Level-1 Elevator (3) Journey Stairs (6) Tangible Exhibition (7) Mechanical Room Viewport (8) Dam Viewport (9)

Stairs (ii) 


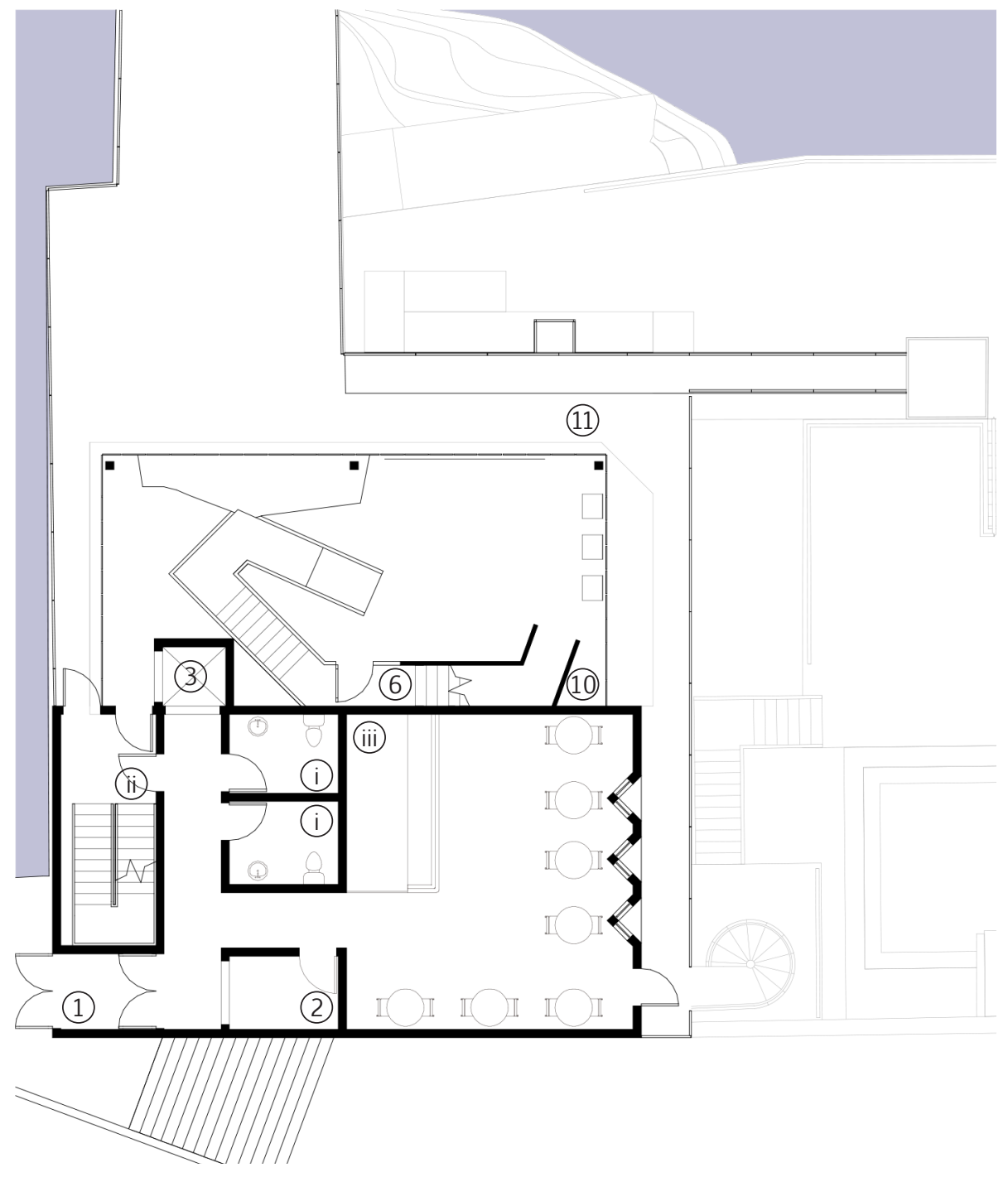

Figure 70: Level 1 Entrance (1) Information Kiosk (2) Elevator (3) Journey Stairs (6) Immediate Context Exhibition (10) Connection to Dam Deck (11) Washroom Facilities (i) Stairs (ii) Cafe (iii) 


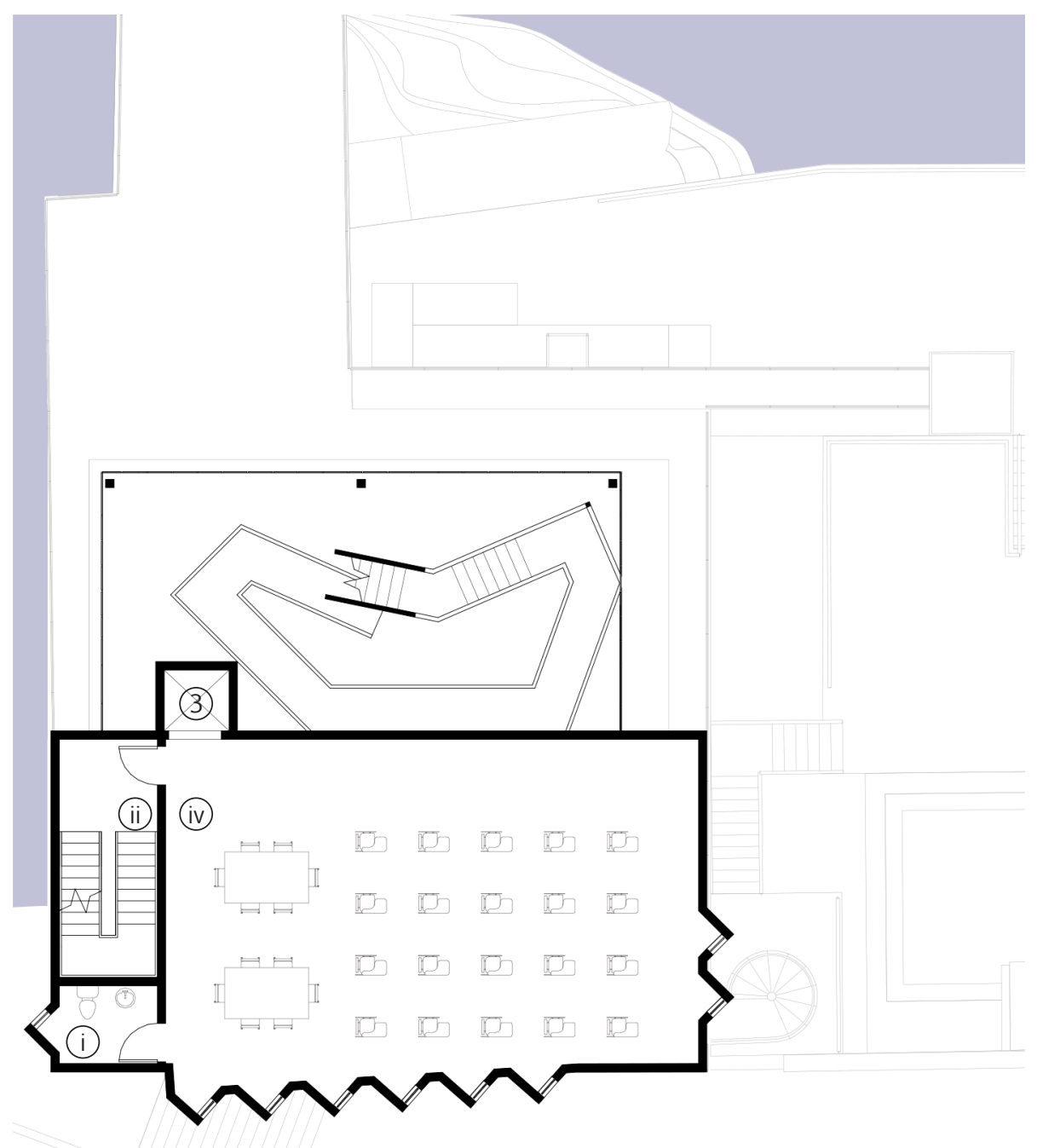

Figure 71: Level 2

Elevator (3)

Washroom Facilities (i)

Stairs (ii)

Classroom (iv) 


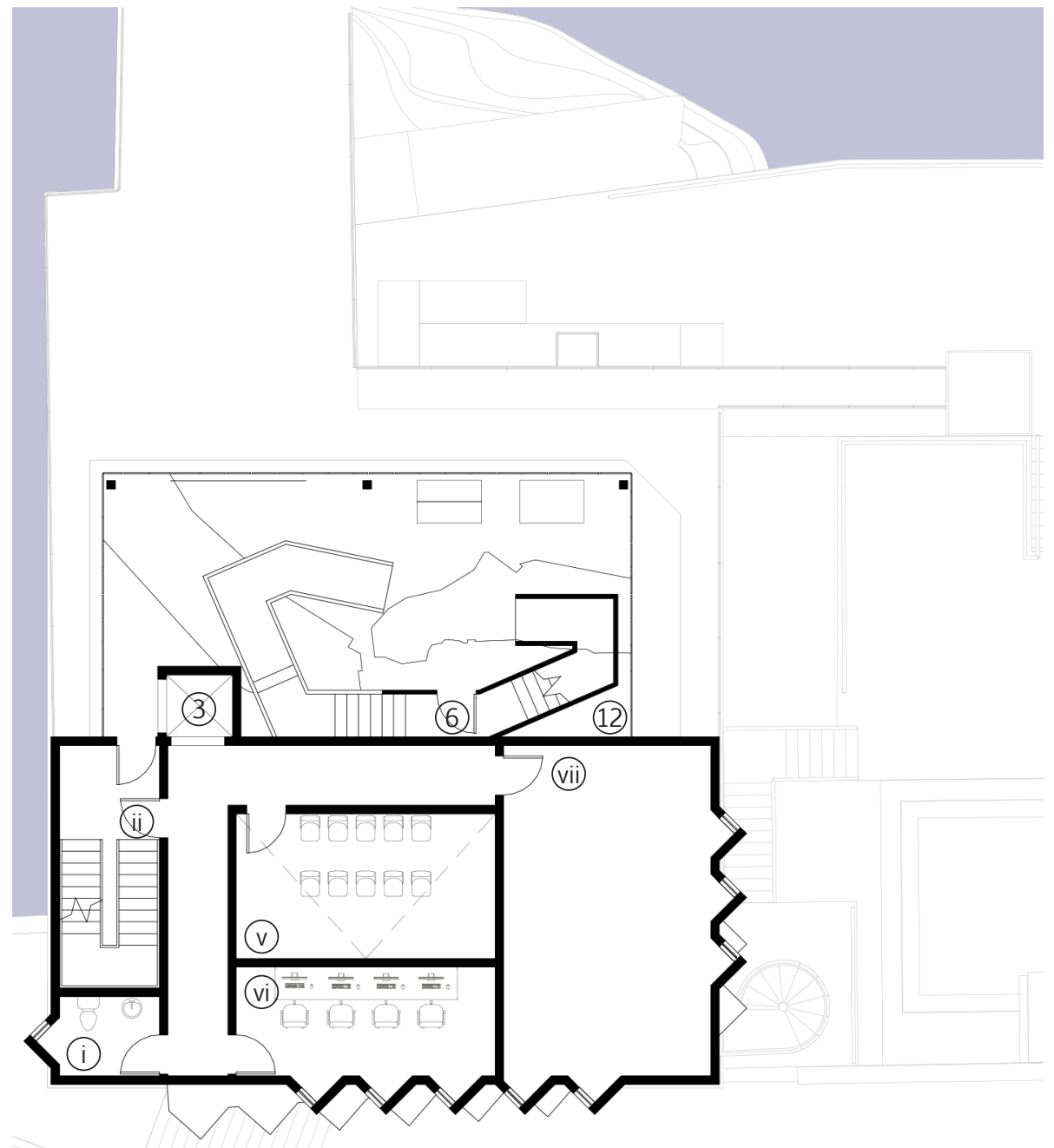

Figure 72: Level 3 Elevator (3)

Journey Stairs (6)

Surrounding Context Exhibition (12)

Washroom Facilities (i) Stairs (ii)

Theatre (v)

Media Room (vi)

Staff Facilities (vii) 


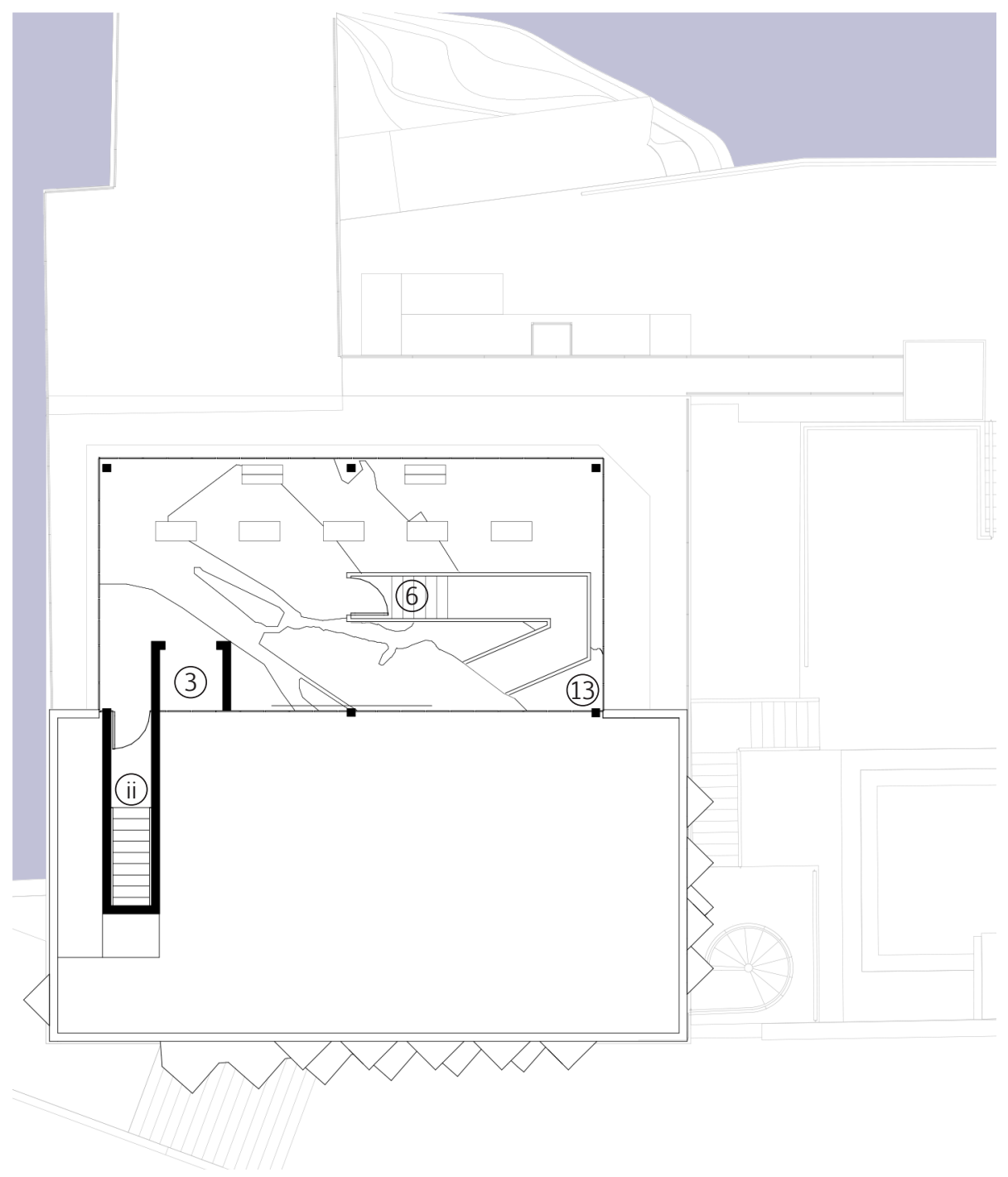

Figure 73: Level 4 Elevator (3)

Journey Stairs (6)

Greater Context Exhibition (13)

Stairs (ii) 


\section{Exhibitions 3.4:}

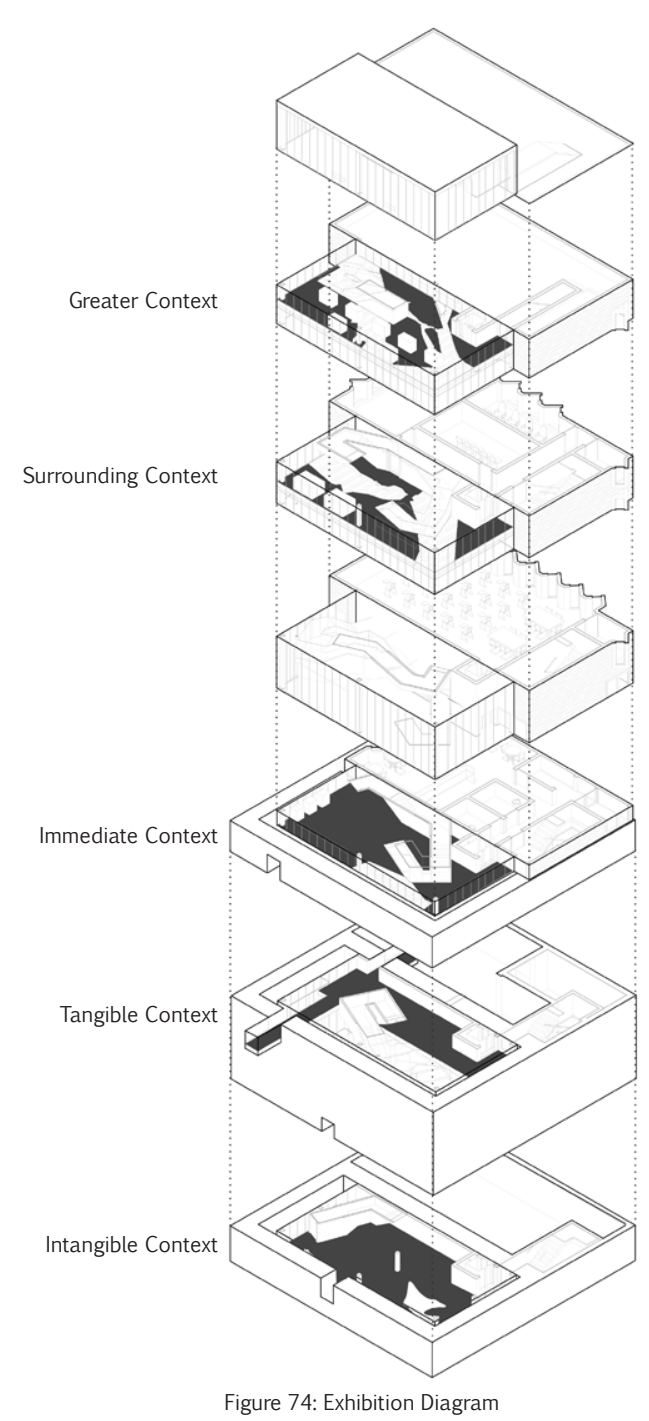

Each level of the experience space focuses on a dif-

ferent aspect of the Chaudière Falls. There would be various methods of displaying the information located within the exhibits, ranging from models, illustrations, diagrams, to images, as well as artifacts. 


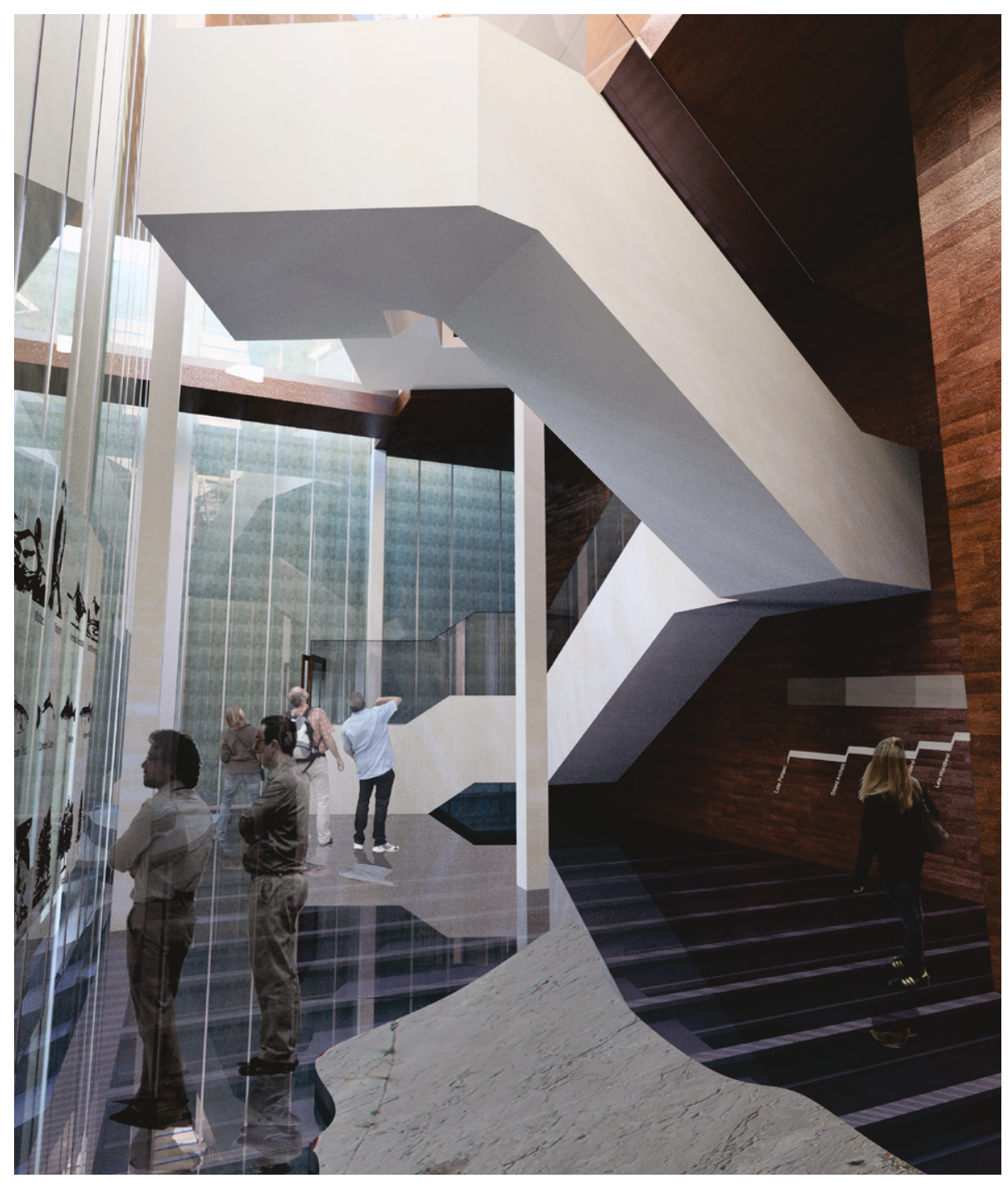

Figure 75: Intangible Context

When you first arrive to the intangible context you see the earth and bedrock below a glass floor that allows you to walk on it. The bedrock is built up in certain areas, and is deeper in others. Around this bedrock, water flows, and it is here that water would have been located both for the advancement of the industrial infrastructure, but also before human intervention occurred. The other information presented will be etched on the glass walls with the background of the existing concrete structure showcasing that you are located deep within the structure.

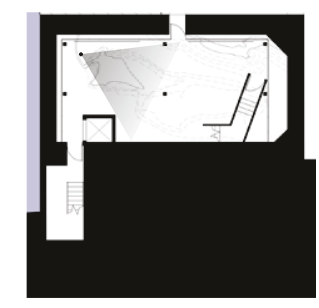




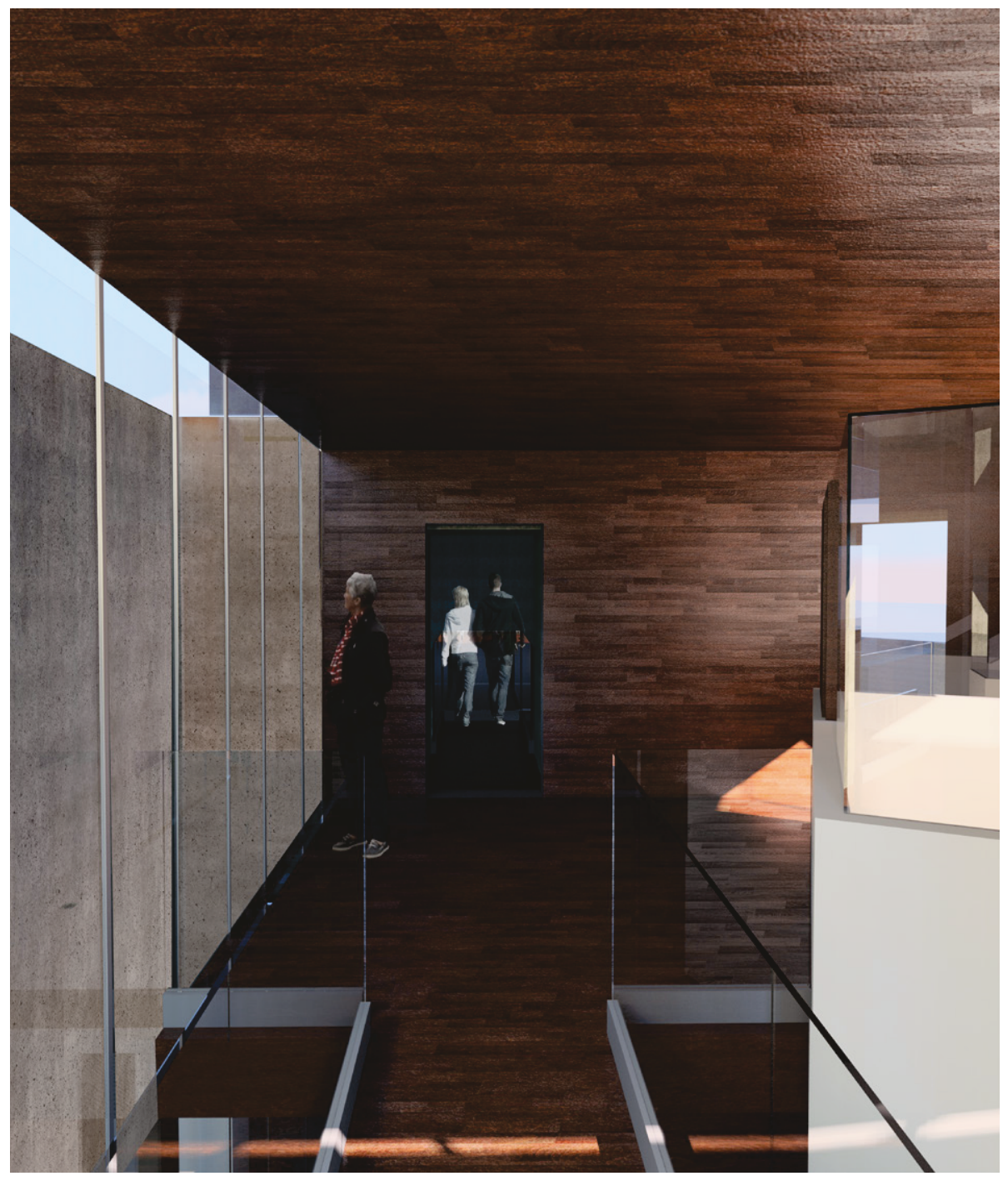

Within the tangible context you will find artifacts that exist on site including grindstones, the turbine, furnace, and the timber lifting device. Some of these are left in situ, while others have been moved to properly display them

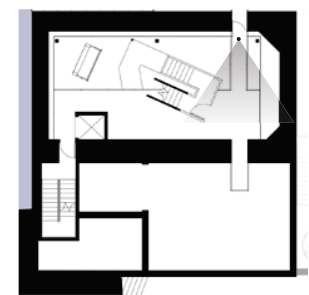




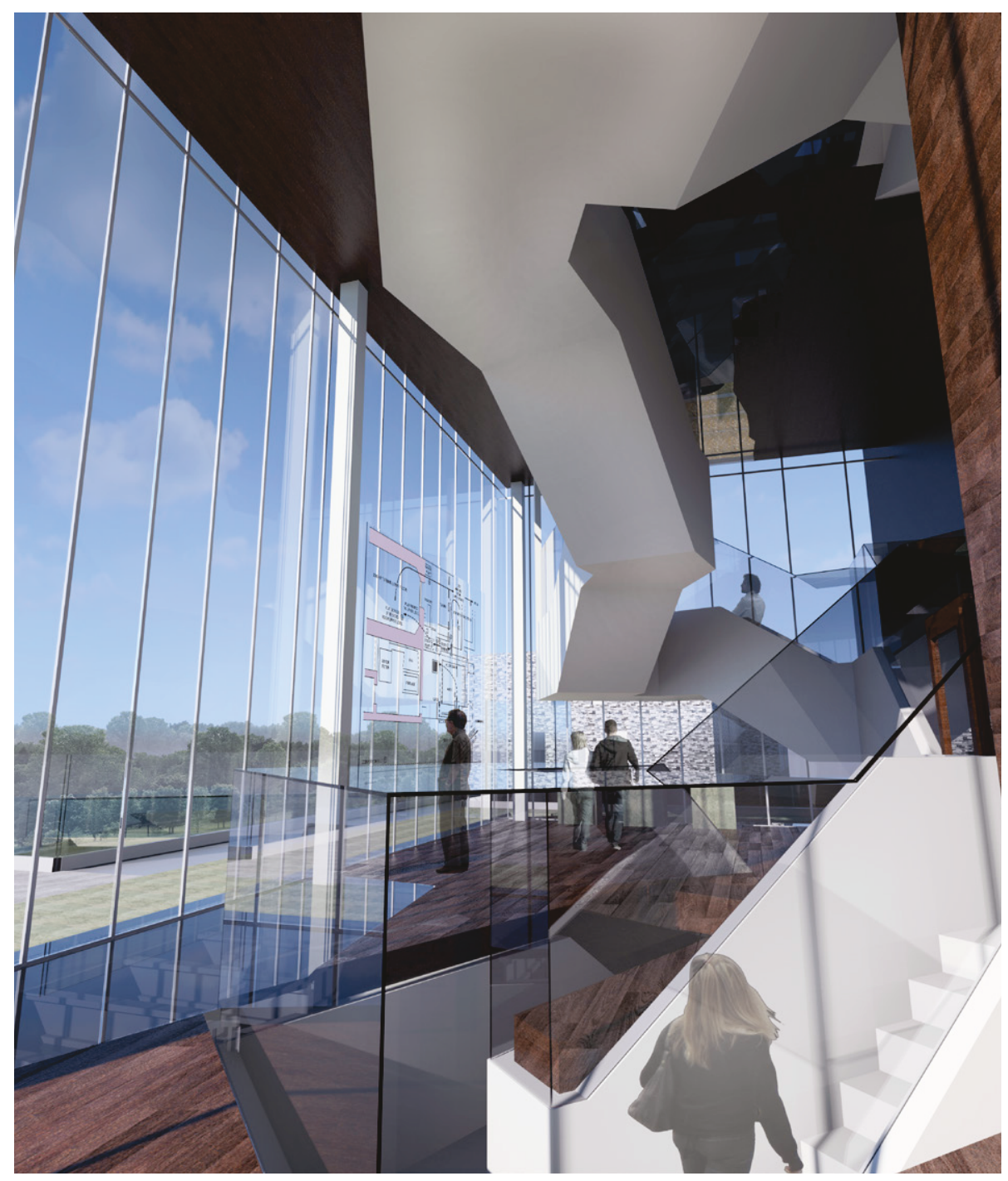

Figure 77: Immediate Context

Within the immediate context, the damages, character defining elements, and year of construction are examined. This happens in both plan and section. The working mill diagram will be etched on glass so that the connection between the diagram and the remaining infrastructure can be made.

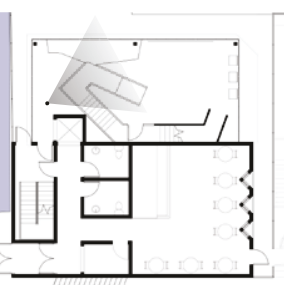




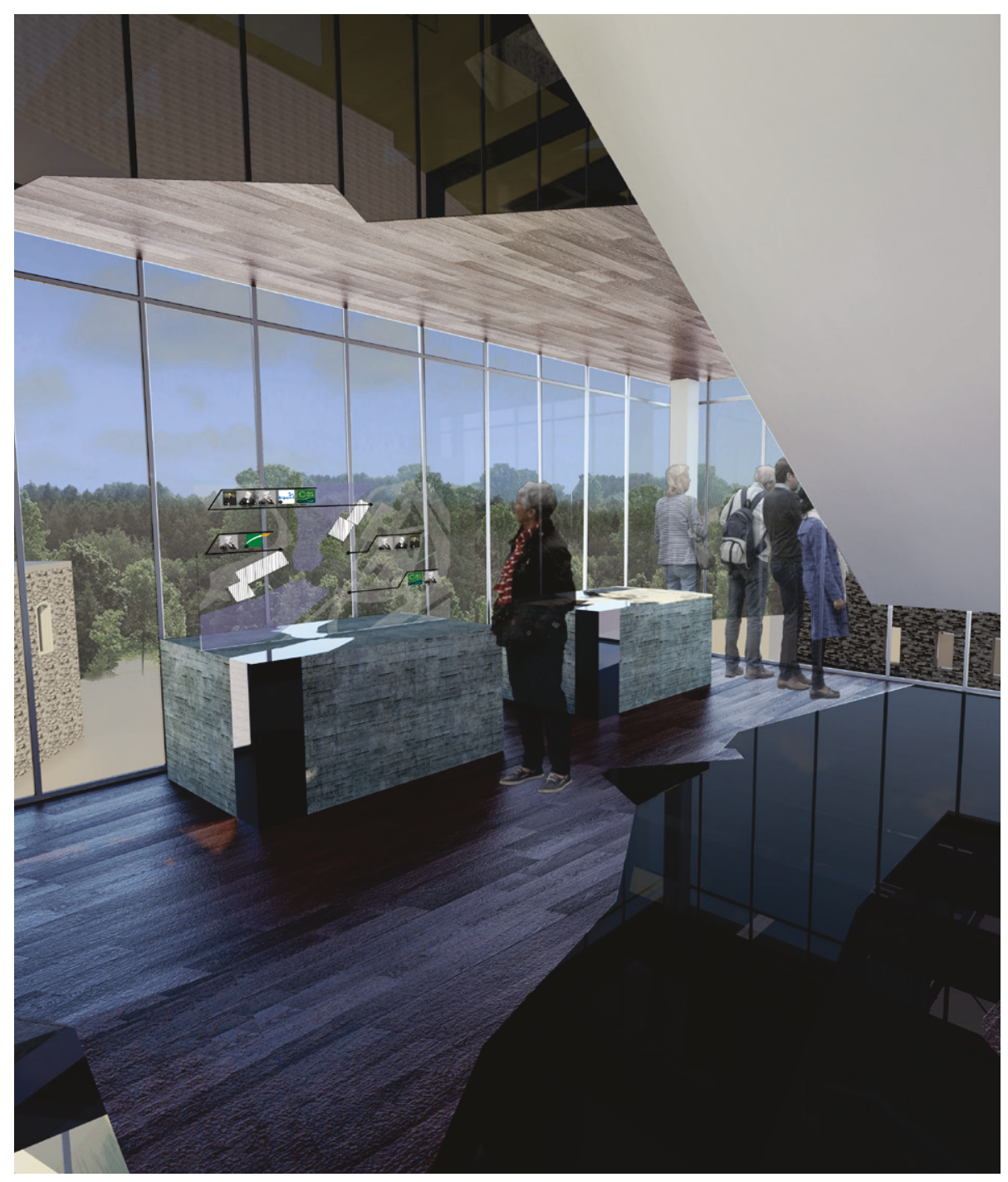

Figure 78: Surrounding Context

The surrounding context examines the construction dates, and who owned and operated the various surrounding buildings. It also looks at how the site has evolved over time. These will be shown through diagrams, models, and images.

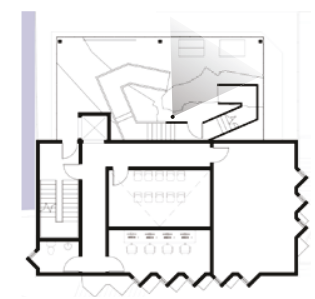




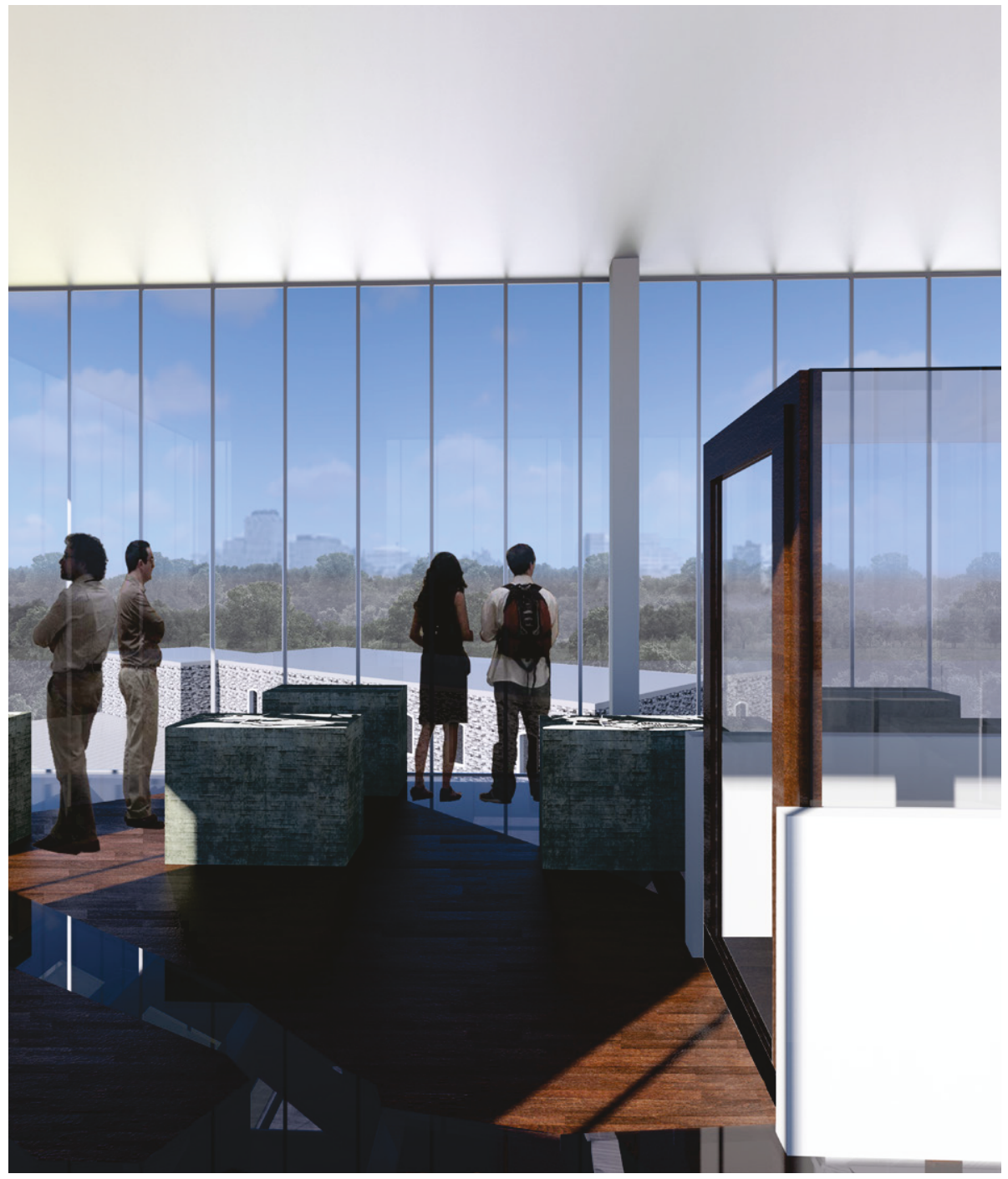

Figure 79: Greater Context

The final level looks at how the site has evolved overtime on the larger scale, who originally owned the land, and how the industry progressed, including the devastation caused by fire. This level will look at the current infrastructure, and the opportunity for the future. The work that shows the site progression will be displayed through model, and other information will be displayed through images and diagrams. 


\section{Endnotes Part 3:}

104. The ICOMOS Charter for the Interpretation and Presentation of Cultural Heritage Sites. Rep. Quebec: ICOMOS, 2008, 7.

105. The ICOMOS Charter for the Interpretation and Presentation of Cultural Heritage Sites. Rep. Quebec: ICOMOS, 2008, 7.

106. The ICOMOS Charter for the Interpretation and Presentation of Cultural Heritage Sites. Rep. Quebec: ICOMOS, $2008,7$.

107. The ICOMOS Charter for the Interpretation and Presentation of Cultural Heritage Sites Rep. Quebec: ICOMOS, $2008,7$.

108. The ICOMOS Charter for the Interpretation and Presentation of Cultural Heritage Sites. Rep. Quebec: ICOMOS, 2008, 9 .

109. The ICOMOS Charter for the Interpretation and Presentation of Cultural Heritage Sites. Rep. Quebec: ICOMOS, 2008, 9 .

110. The ICOMOS Charter for the Interpretation and Presentation of Cultural Heritage Sites. Rep. Quebec: ICOMOS, 2008, 10.

111. The ICOMOS Charter for the Interpretation and Presentation of Cultural Heritage Sites. Rep. Quebec: ICOMOS, 2008, 10.

112. The Nara Document of Authenticity, ICOMOS, 1994. 2.

113. The ICOMOS Charter for the Interpretation and Presentation of Cultural Heritage Sites. Rep. Quebec: ICOMOS, 2008, 11

114. The ICOMOS Charter for the Interpretation and Presentation of Cultural Heritage Sites. Rep. Quebec:ICOMOS, 2008, 11.

115. The ICOMOS Charter for the Interpretation and Presentation of Cultural Heritage Sites. Rep. Quebec: ICOMOS, 2008, 12

116. The ICOMOS Charter for the Interpretation and Presentation of Cultural Heritage Sites. Rep. Quebec: ICOMOS, 2008, 12.

117. The ICOMOS Charter for the Interpretation and Presentation of Cultural Heritage Sites. Rep. Quebec: ICOMOS, 2008, 13 


\section{Conclusion:}

The question stated at the beginning of this thesis was: How can the traces of the past be interpreted and translated into an architectural language that allows the journey to become the means of dissemination?

This has been accomplished through the analysis and review of the many tangible layers left behind by the past infrastructure. As well as referencing the intangible layers that are also key in the history of the area. Several different means of interpretation have subsequently been applied to the resulting analysis.

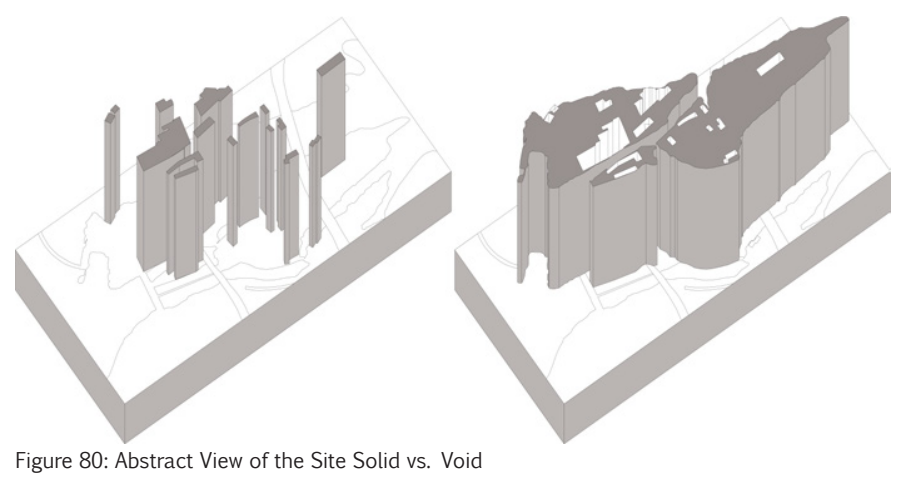

This is further illustrated through the application of an architectural language that speaks to the site's heritage and function. This language will begin to tell the story by one's journey through the site's history. This is meant to reflect the intangible heritage of storytelling that was important to the Algonquin community. This creates a relationship between the built infrastructures with its tangible components to the intangible aspect of storytelling. This will create spaces that link both aspects together similar to the way the Chaudière Falls tangible and intangible history is linked. The construction of an Interpretation Centre will then continue the evolution that has marked the site so prevalently. The Interpretation Centre provides both an archive of the past while also providing a platform for new forms of engagement with the historic Chaudière Falls. 
Appendix 1 - Site Model:
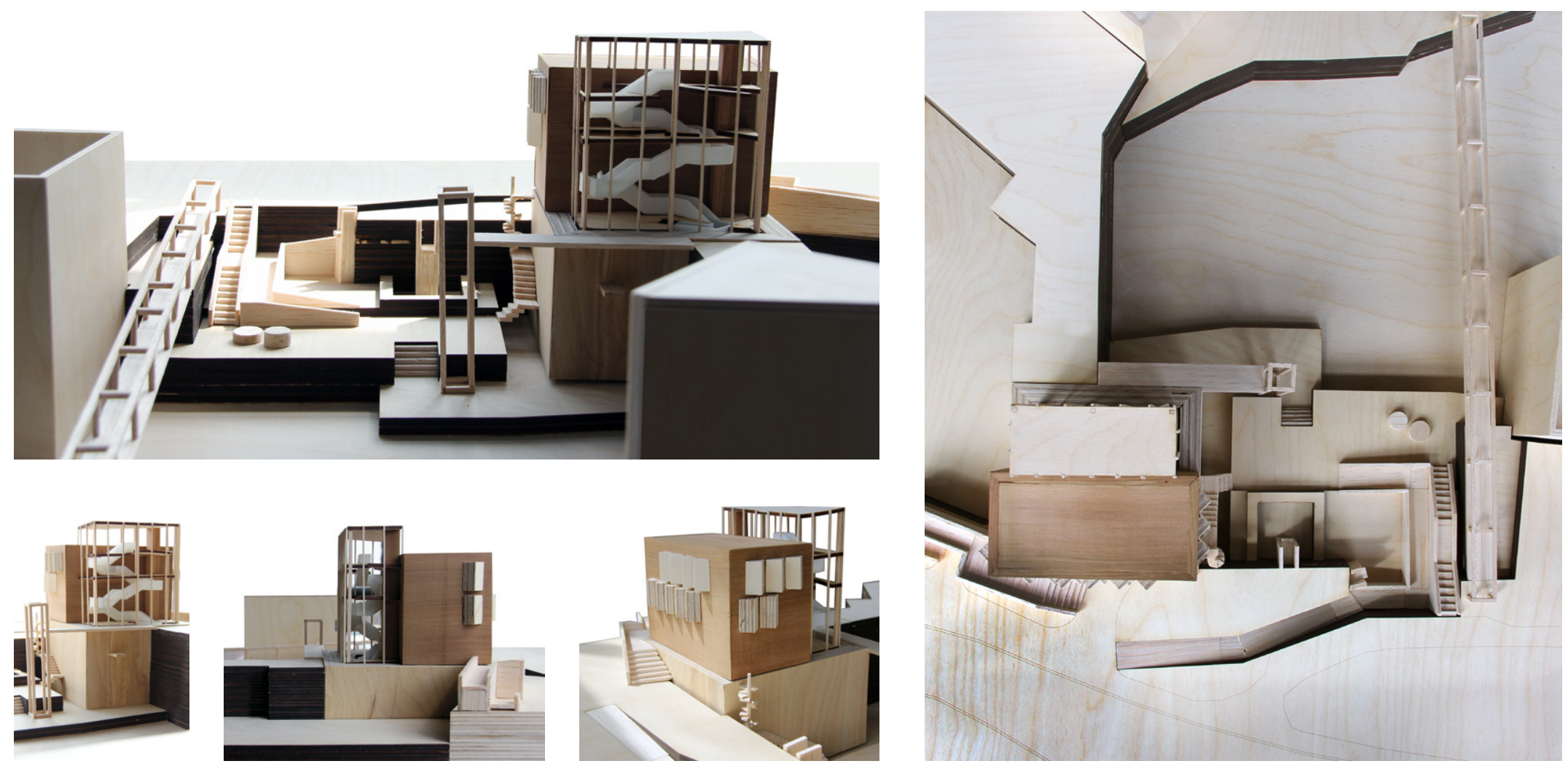

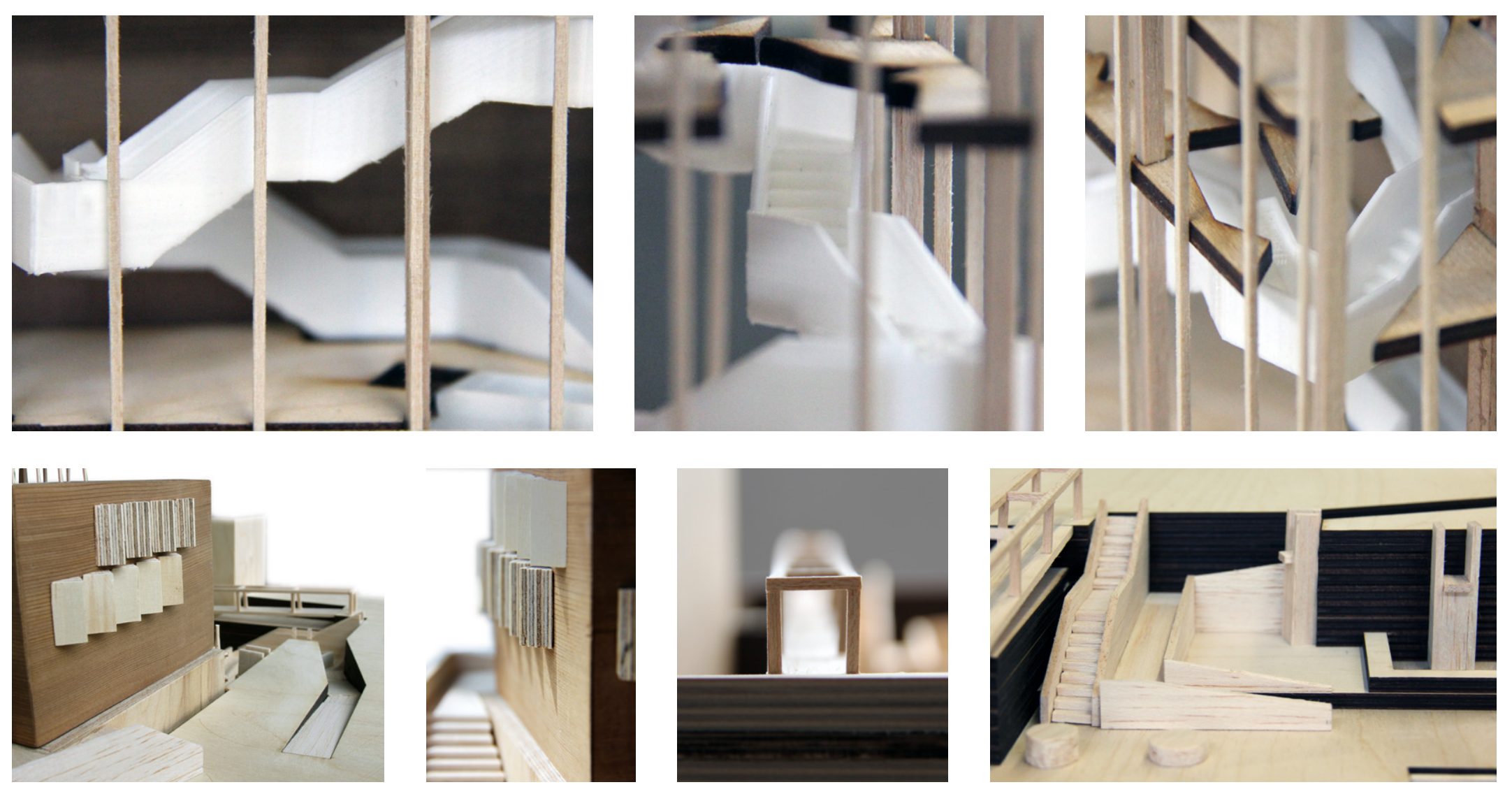


\section{Appendix 2 - Process:}
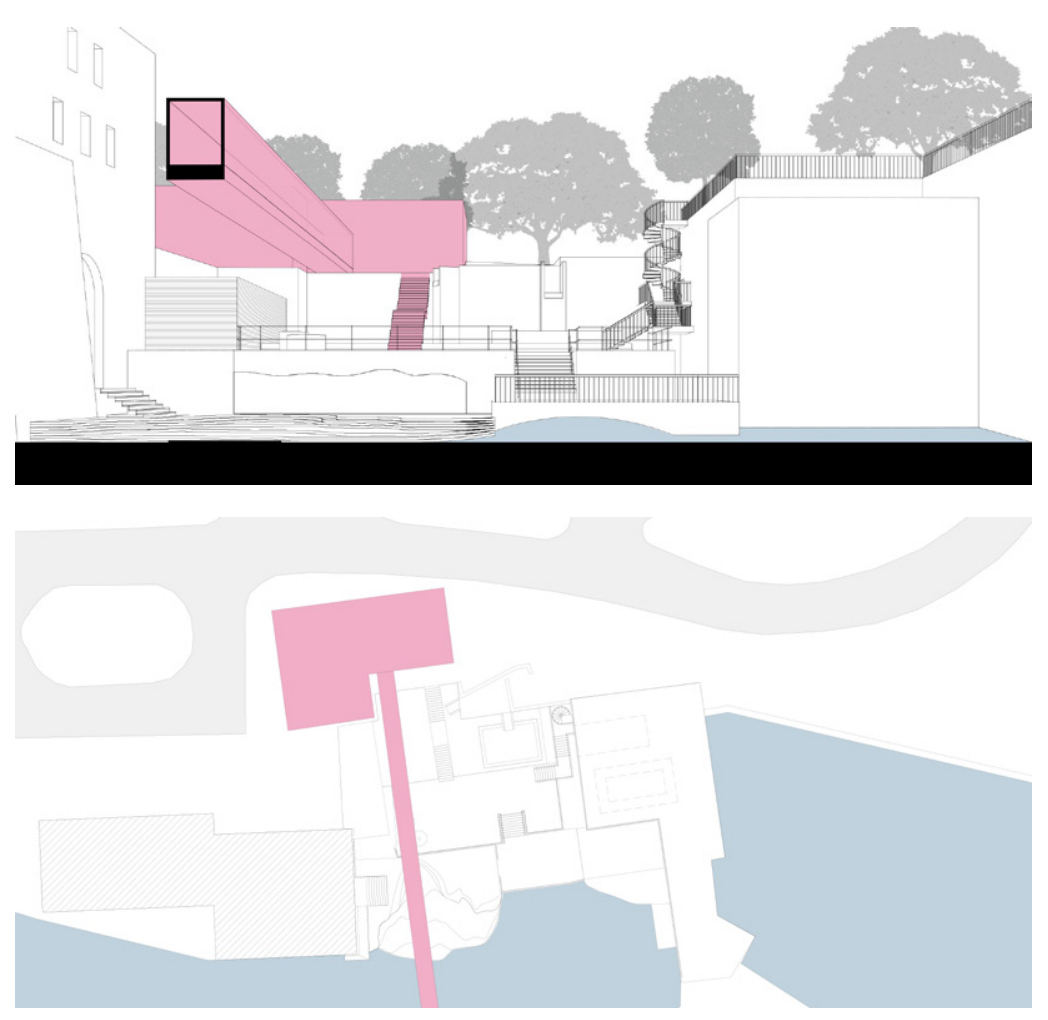

Colloquium 2: Option 1
The project began with an analysis of different massing options for Colloquium 2. This included where the Interpretation Centre would be located, (within the ruins or outside of the ruins) and different methods of moving people through the site (ramp, bridge, or elevator options.)

It was established that a hybrid would be the best option. This was further explored for Colloquium 3. 

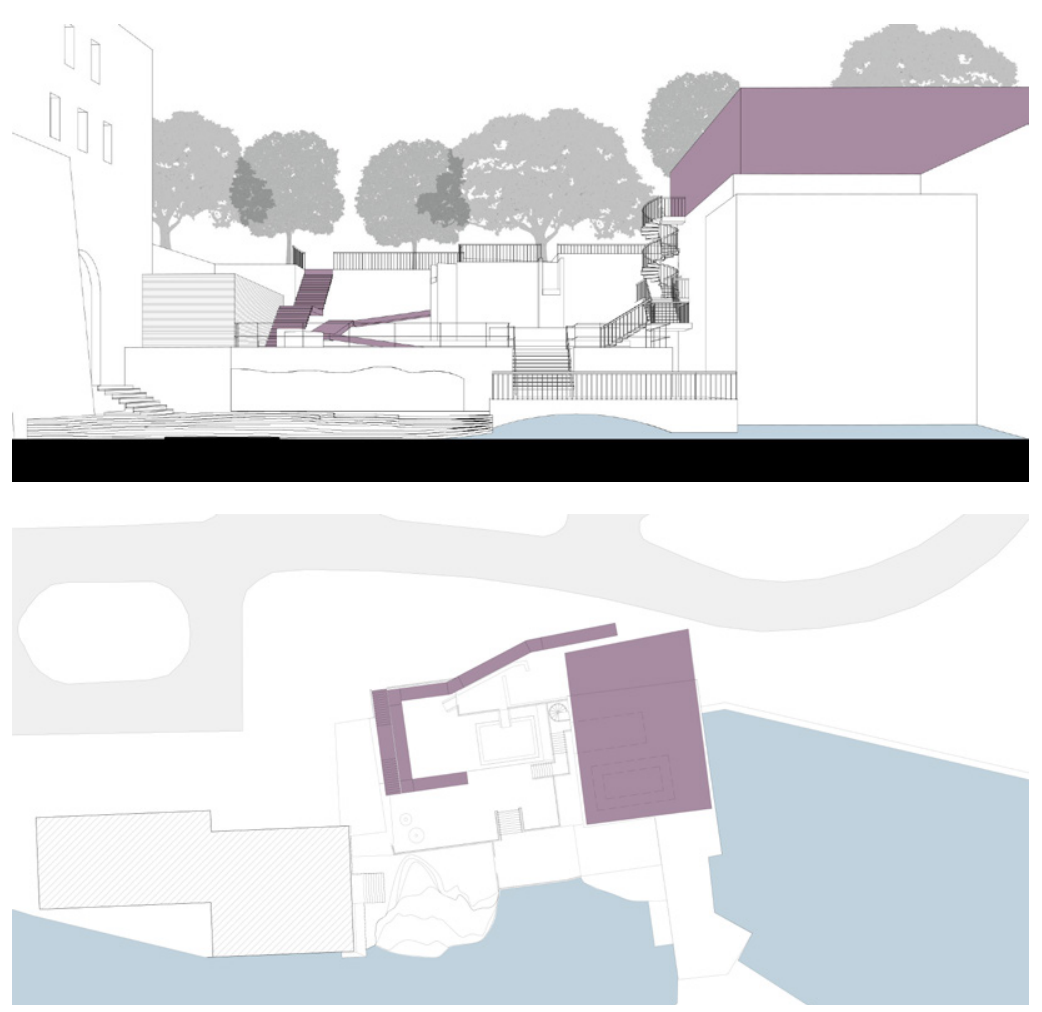

Colloquium 2: Option 2
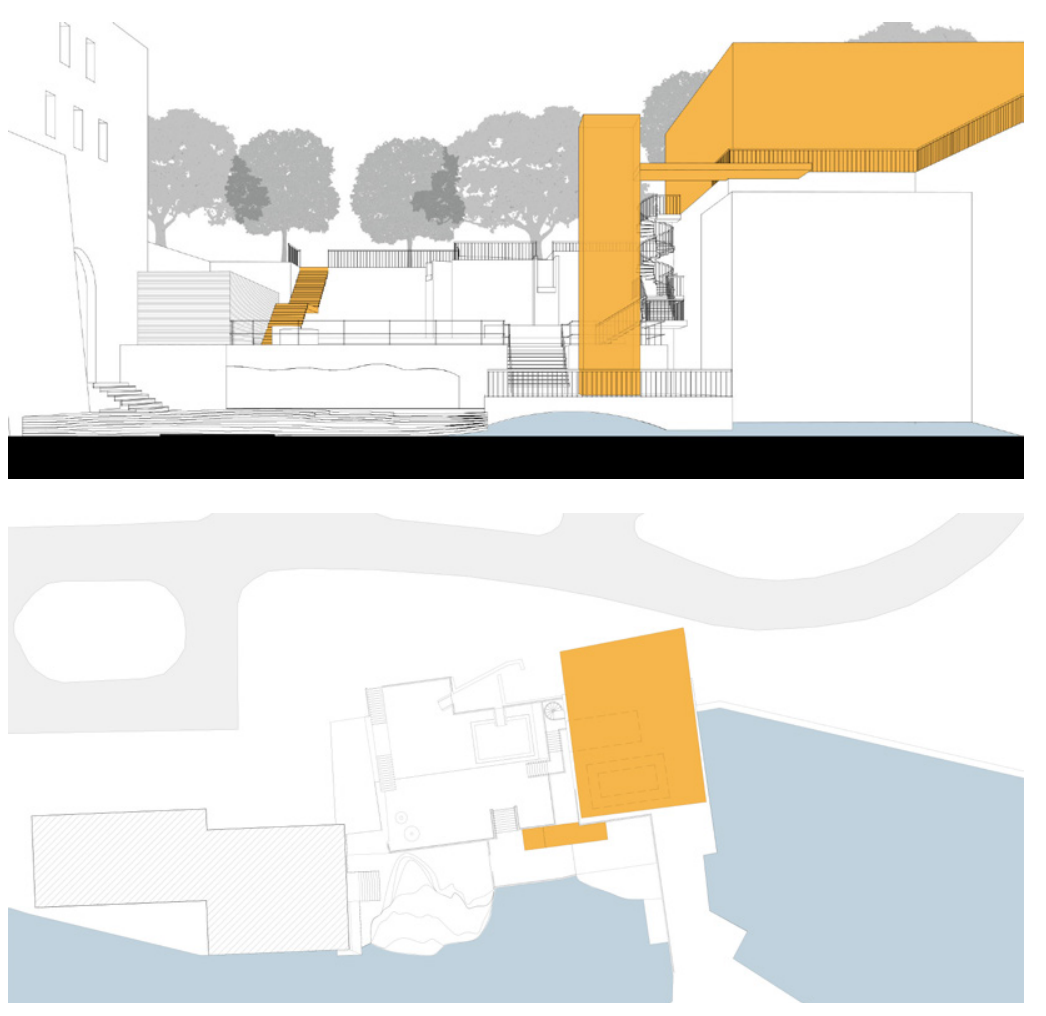

Colloquium 2: Option 3 

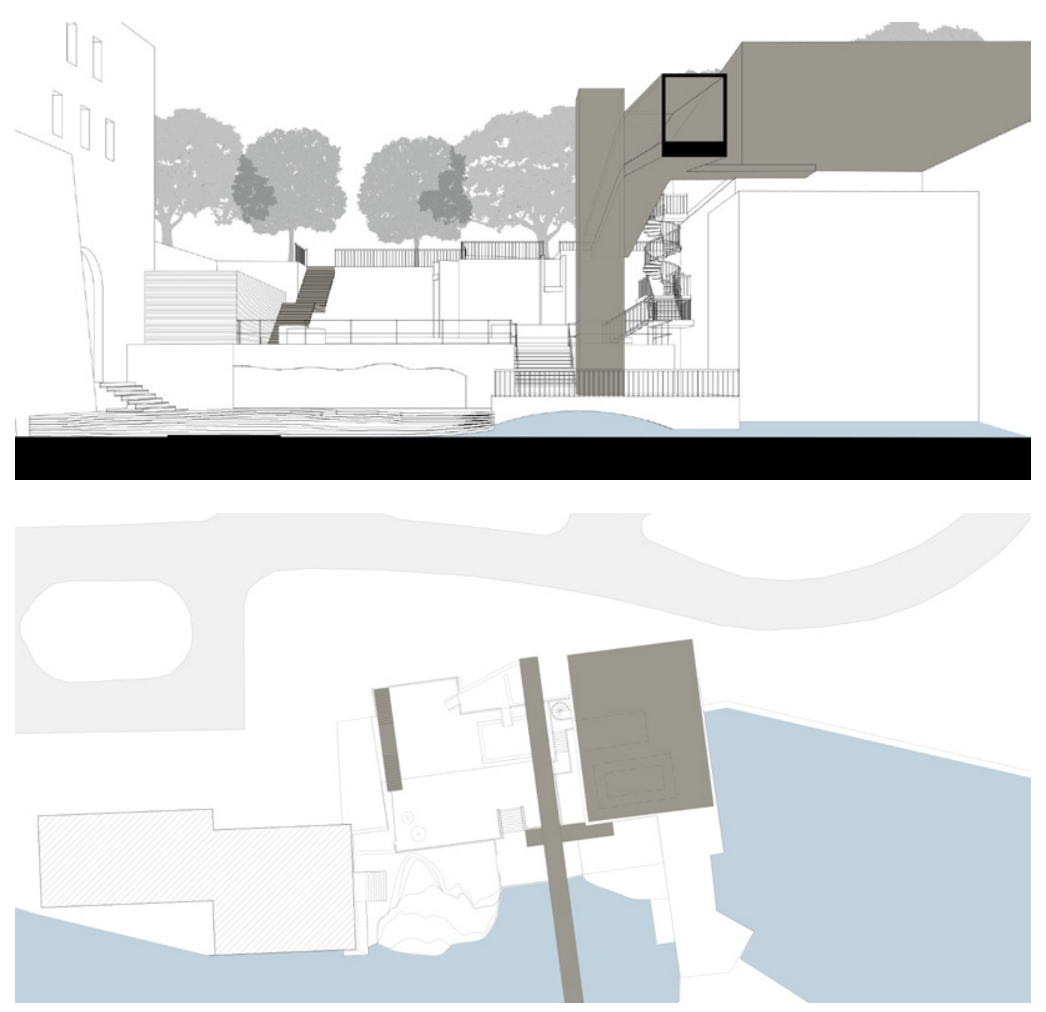

Colloquium 2: Hybrid Option
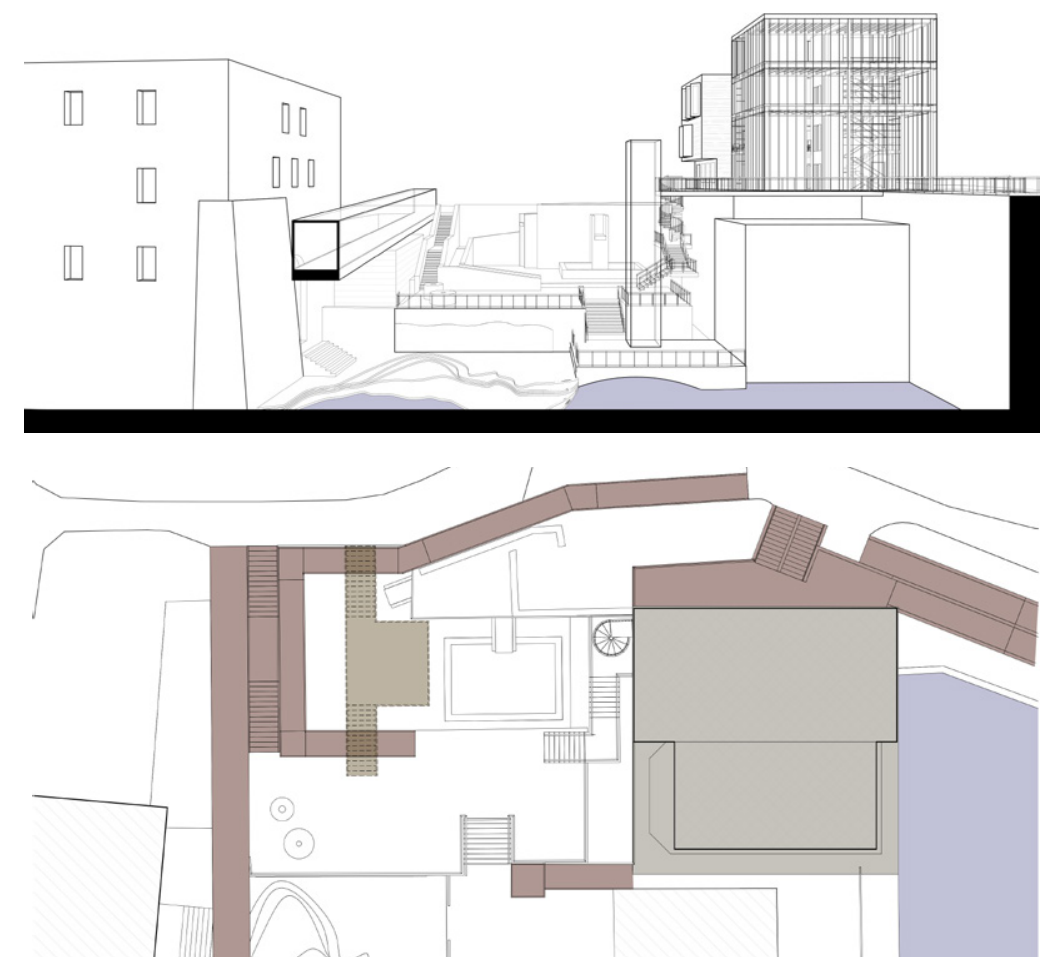

Colloquium 3: Proposal 


\section{Bibliography:}

Bond, Courtney C. J., and Robert U. Mahaffy. "Where Rivers Meet: An Illustrated History of Ottawa." Woodland Hills, CA: Windsor Publications, 1984.

Commonwealth Historic Resource Management Limited. The Chaudière Falls Hydroelectric District Grinder Room Architectural Approach. Rep. Ottawa: Commonwealth Historic Resource Management Limited, 2005.

Durham Peters, John. "Communication as Dissemination." Communication as ...: Perspectives on Theory. Thousand Oaks, CA: Sage Publications, 2006. 211-222.

Earl, Jeff. Thompson Perkins and Bronson Pulp Mills Site History and Evolution. Rep. Ottawa: Fern Mackenzie Consulting Architectural Historian, 2006.

HP Engineering. Bronson Pulp Mill Ruins National Capital Commission Draft Structural Assessment Report. Rep. Ottawa: National Capital Commission, 2015.

Izquierdo Tugas, Pere, Jordi Juan Tresserras, and Juan Carlos Matamala Mellin, Eds. The Hicira Handbook - Heritage Interpretation Centres. Rep. Barcelona: Diputació De Barcelona, 2005.
Jenkins, Phil. An Acre of Time. Toronto: Macfarlane Walter \& Ross, 1996.

QLF Canada, comp. A Background Study for the Nomination of the Ottawa River Under the Canadian Heritage Rivers System. Publication. Petawawa: Canadian Heritage Rivers System, 2005.

Ross, Alexander Herbert Douglas. Ottawa, past and Present. Toronto: Musson Book, 1927.

Taylor, John H. Ottawa: An Illustrated History. Toronto: J. Lorimer, 1986.

Sattelberger, Peter, M.A., and Jeff Earl, M.Soc.Sc. Richmond Landing/Bronson Mill Ruins Public Access: Heritage Guidance Document. Rep. Maberly: Past Recovery Archaeological Services, 2015.

Standards and Guidelines for the Conservation of Historic Places in Canada: A Federal, Provincial and Territorial Collaboration. 2nd ed. Ottawa: Parks Canada, 2010. Print.

Stephenson, J. Newell. The Manufacture of Pulp and Paper; a Textbook of Modern Pulp and Paper Mill Practice. New York: McGraw-Hill Book, 1927. 
The Canadian Pulp \& Paper Association, Ed. A Handbook of the Canadian Pulp and Paper Industry. Rep. Montreal: Canadian Pulp and Paper Association, 1920.

The ICOMOS Charter for the Interpretation and Presentation of Cultural Heritage Sites. Rep. Quebec: ICOMOS, 2008.

Tilden, Freeman. Interpreting Our Heritage. Chapel Hill: U of North Carolina, 1977.

WordImage. Richmond Landing and Bronson Pulp Mill Ruins Interpretive Content Research. Rep. Ottawa: Department of Canadian Heritage, 2015. 


\section{Online Sources:}

"Interpretive Planning." Interpretive Planning. Scottish Natural Heritage, 7 Oct. 2015. Web. 04 Jan. 2016. <http://www.snh. gov.uk/policy-and-guidance/heritage-interpretation/interpretive-planning/>.

"Biography - BRONSON, HENRY FRANKLIN - Volume XI (18811890) - Dictionary of Canadian Biography." N.p., n.d. Web. 03 Oct. 2015. <http://www.biographi.ca/en/bio/bronson_henry_franklin_11E.html>.

"Biography - EDDY, EZRA BUTLER - Volume XIII (1901-1910)

- Dictionary of Canadian Biography.". N.p., n.d. Web. 03 Oct. 2015. <http://www.biographi.ca/en/bio.php?id_nbr=6698>.

"Chaudière Falls in the Outaouais Region." Articles. N.p., n.d. Web. 03 Oct. 2015. http://www.ameriquefrancaise.org/en/article-719/Chaudi\%C3\%A8re_Falls_in_the_Outaouais_Region. html

"Chaudière Falls." Energy Ottawa Generation.Web. 03 Oct. 2015. <http://energyottawa.com/generation/chaudiere-falls $/>$.

"Erskine Henry Bronson." The Canadian Encyclopedia. N.p., n.d. Web. 03 Oct. 2015. <http://www.thecanadianencyclopedia.ca/en/article/erskine-henry-bronson/>.
"GeoOttawa." GeoOttawa. N.p., n.d. Web. 03 Oct. 2015. $<$ http://maps.ottawa.ca/geoOttawa/>.

"Henry Franklin Bronson." The Canadian Encyclopedia. N.p., n.d. Web. 03 Oct. 2015. <http://www.thecanadianencyclopedia.ca/en/article/henry-franklin-bronson/>.

"HistoricPlaces.ca - HistoricPlaces.ca." HistoricPlaces.ca - HistoricPlaces.ca. N.p., n.d. Web. 03 Oct. 2015. <http://www.historicplaces.ca/en/rep-reg/placelieu.aspx?id=4360>.

"History and Architecture of the Chaudiére Falls." History and Architecture of the Chaudiére Falls. N.p., n.d. Web. 03 Oct. 2015. <http://aix1.uottawa.ca/ weinberg/chaudier.html>.

"NCC Plans Access to 'hidden Treasure' of Bronson Pulp Mill Ruins, Richmond Landing." Ottawa Citizen. N.p., 08 Oct. 2014. Web. 03 Oct. 2015. <http://ottawacitizen.com/news/ local-news/ncc-plans-access-to-hidden-treasure-of-bronsonpulp-mill-ruins-richmond-landing $>$.

"Pulp And Paper In Canada: Its First Century." Pulp and Paper Canada. N.p., n.d. Web. 03 Oct. 2015. <http://www.pulpandpapercanada.com/innovation/pulp-and-paper-in-canada-itsfirst-century-1000152489>. 
"Pulp and Paper Industry." The Canadian Encyclopedia. N.p., n.d. Web. 03 Oct. 2015. <http://www.thecanadianencyclopedia.ca/en/article/pulp-and-paper-industry/>.

"Sharing Ottawa's Stories | Ottawagraphy." Sharing Ottawa's Stories | Ottawagraphy. N.p., n.d. Web. 03 Oct. 2015. <http:// www.ottawagraphy.ca/>.

“The District - Vision Chaudiere." Vision Chaudiere. N.p., n.d. Web. 03 Oct. 2015. <http://visionchaudiere.ca/the-district/>.

Larkham, Peter J, and Gunila Jiven "Sense of Place, Authenticity and Character: A Commentary". Journal of Urban Design, Vol. 8, No. 1, 67-81, 2003. 68

\section{Precedents}

Bollack, Françoise Astorg. Old Buildings, New Forms: New Directions in Architectural Transformations. New York: Monacelli, 2013.

"Cultuurpark Westergasfabriek." Gustafson Porter. Ed. Gustafson Porter. N.p., 25 Aug. 2013. Web. 04 Nov. 2015. <http:// www.gustafson-porter.com/westergasfabriek/>.
“Duisburg Nord Landscape Park, DE." Duisburg Nord Landscape Park, DE. Ed. Latz+Partner. Latz+Partner, n.d. Web. 26 Sept. 2015. <http://www.latzundpartner.de/en/projekte/postindustrielle-landschaften/landschaftspark-duisburg-nord-de/>.

LeFevre, Camille. "Mill City Museum." Architectural Record Feb. 2004: 122-26.

"Paddington Reservoir Gardens." Paddington Reservoir Gardens. Ed. Tonkin Zulaikha Greer. Tonkin Zulaikha Greer, 2009. Web. 4 Nov. 2015. <Http://Www.Tzg.Com.Au/Project/Paddington-Reservoir/>.

“Pointe-à-callière Museum." Pointe-à-callière Museum. Ed. Dan Hanganu. Dan Hanganu Architectes, n.d. Web. 24 Sept. 2015. <http://www.hanganu.com/index.php/en/projects/28-projets/culturel/1995/59-pac-em>. 


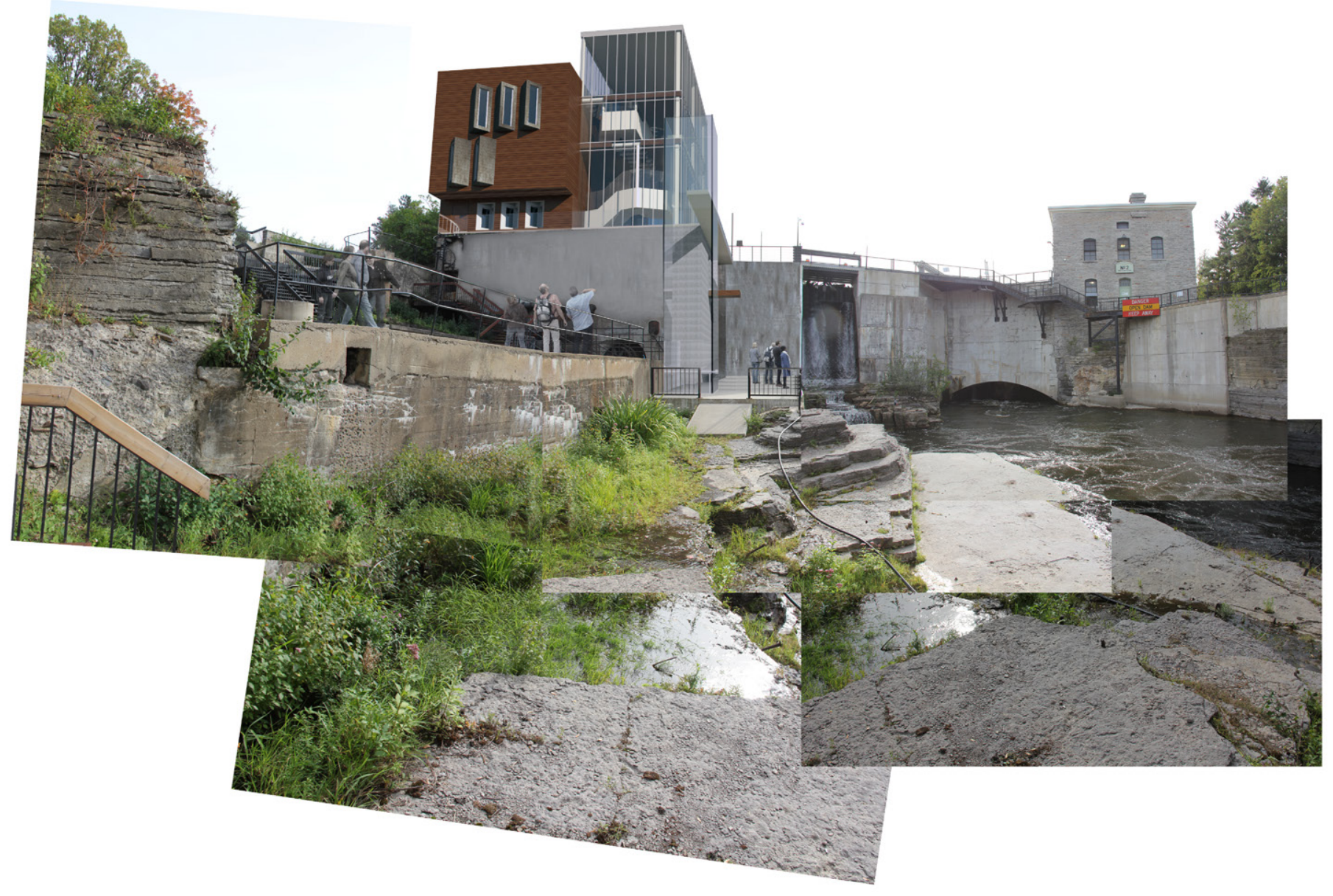

